\title{
nordan
}

\section{GRÄNSHINDERRÅDETS ÅRSRAPPORT 2015}

MED KOMMENTARER FRÅN DE NORDISKA REGERINGARNA

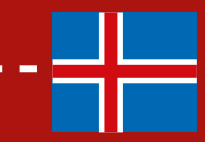

+96

$-\frac{1}{7}$
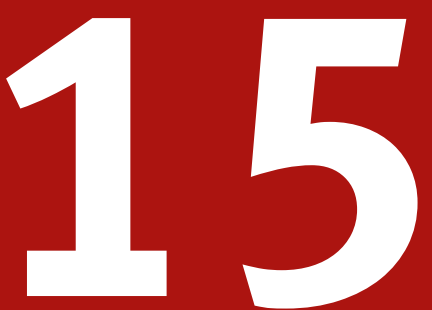
Gränshinderrådets årsrapport 2015

med kommentarer från de nordiska regeringarna

ISBN 978-92-893-4423-4 (PRINT)

ISBN 978-92-893-4424-1 (PDF)

http://dx.doi.org/10.6027/ANP2015-797

ANP 2015:797

ISSN 2445-6594

(C) Nordiska ministerrådet 2015

Layout: Peter Daniel Olsen/Resonans Kommunikation

Foto: S. 6: Johannes Jansson

s. 12, 25, 37, 79, 95, 112: Yadid Levy - s. 23: Banjamin Suomela

s. 20,114 : norden.org

s. 30, 35, 46, 55, 61, 62, 80, 87, 90, 97, 103: Karin Beate Nøsterud

s. 45, 51: Magnus Fröderberg - s. 57: Johannes Jansson

s. 66, 99, 106: Silje Bergum Kinsten

Journalistisk bearbetning: Arvidsson Kultur\&Kommunikation AB

Beräkningarna är gjorda av Britt Andresen, chefsanalytiker,

Øresundsinstituttet

Tryck: Rosendahls Schultz-Grafisk, Albertslund

Upplaga: 1500

Printed in Denmark

www.norden.org/nordpub

\section{Det nordiska samarbetet}

Det nordiska samarbetet är ett av världens mest omfattande regionala samarbeten. Det omfattar Danmark, Finland, Island, Norge och Sverige samt Färöarna, Grönland och Åland.

Det nordiska samarbetet är politiskt, ekonomiskt och kulturellt förankrat och är en viktig partner i europeiskt och internationellt samarbete. Den nordiska gemenskapen arbetar för ett starkt Norden i ett starkt Europa.

Det nordiska samarbetet ska stärka nordiska och regionala intressen och värderingar i en global omvärld. Gemensamma värderingar länderna emellan bidrar till att stärka Nordens ställning som en av världens mest innovativa och konkurrenskraftiga regioner.
Nordiska ministerrådet Ved Stranden 18 DK-1061 København K Telefon (+45) 33960200

www.norden.org 
norden

\section{GRÄNSHINDERRÅDETS ÅRSRAPPORT 2015}

MED KOMMENTARER FRÅN DE NORDISKA REGERINGARNA
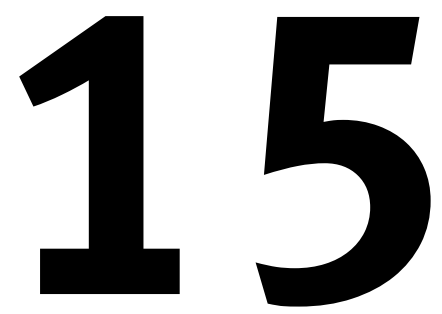

KÖPENHAMN DEN 31 DECEMBER 2015 



\section{De nordiska statsministrarnas deklaration med anledning av den nya strategin och handlingsplanen för avlägsnande av gränshinder i Norden. Den nya strategin och handlingsplanen behandlades vid Nordiska rådets 65:e session i oktober 2013.}

\section{Norden som föregångare för gränslöst samarbete i syfte att skapa jobb och tillväxt}

\begin{abstract}
Vi, statsministrar från Danmark, Finland, Island, Norge och Sverige, lagmanden från Färöarna, landsstyreformanden i Grönland samt lantrådet på Åland, är eniga om att arbetet med att bekämpa gränshinder i syfte att skapa jobb och tillväxt i Norden, är en av det nordiska samarbetets viktigaste utmaningar. Detta gäller inte minst vårt gemensamma behov av att hjälpa unga människor in på arbetsmarknaden.
\end{abstract}

Genom att skapa optimala förutsättningar för individer och företag att verka över gränserna i Norden stärker vi regionens globala konkurrenskraft.

En starkt prioriterad insats är därför arbetet med att aktivt avlägsna gränshinder. Gränshinder kostar, hämmar utveckling och tillväxt och ger färre valmöjligheter för den enskilde.

Gränshinderforum, som tillsattes av de nordiska statsministrarna år 2007, har på ett värdefullt sätt arbetat för att minska gränshinder i Norden. För ytterligare stärka och effektivisera gränshinderarbetet utvecklar vi nu organisationen till ett Gränshinderråd med en ny strategi- och handlingsplan, som trädde i kraft den 1 januari 2014.

\section{Detta innebär att:}

Arbetet kommer att kopplas tätare till den politiska ledningen i Nordiska ministerrådet genom att ordförandelandet i Nordiska ministerrådet också kommer att vara ordförande i Gränshinderrådet.

Nordiska ministerrådets generalsekreterare får en starkare roll i gränshinderarbetet för ministerrådet.

Gränshinderrådets nationella representanter får ett tydligt uppdrag att samarbeta med de aktörer som kan bidra till att få gränshinder lösta för individer och företag i Norden. Detta samarbete omfattar bl.a. ländernas departement och myndigheter, parlamentariker och de gränsregionala informationstjänsterna.

Den nya formen för nordiskt gränshindersarbete kommer att bidra till ett effektivare arbete för att riva gränshinder och öka rörligheten i Norden.

\section{För att uppnå detta bör vi ha som mål:}

- att verka för en öppen och välfungerande gemensam arbetsmarknad

- att skapa bästa möjliga förutsättningar för nordiska företag att verka över gränserna i Norden

- att säkra, så långt det är möjligt, likartad genomförande av EU-rättslig lagstiftning i Norden genom en löpande dialog mellan de nordiska länderna

- att verka för att länderna samråder, när så behövs, när nya eller ändrade lagar och regler införs i syfte att undvika att nya gränshinder uppstår. 


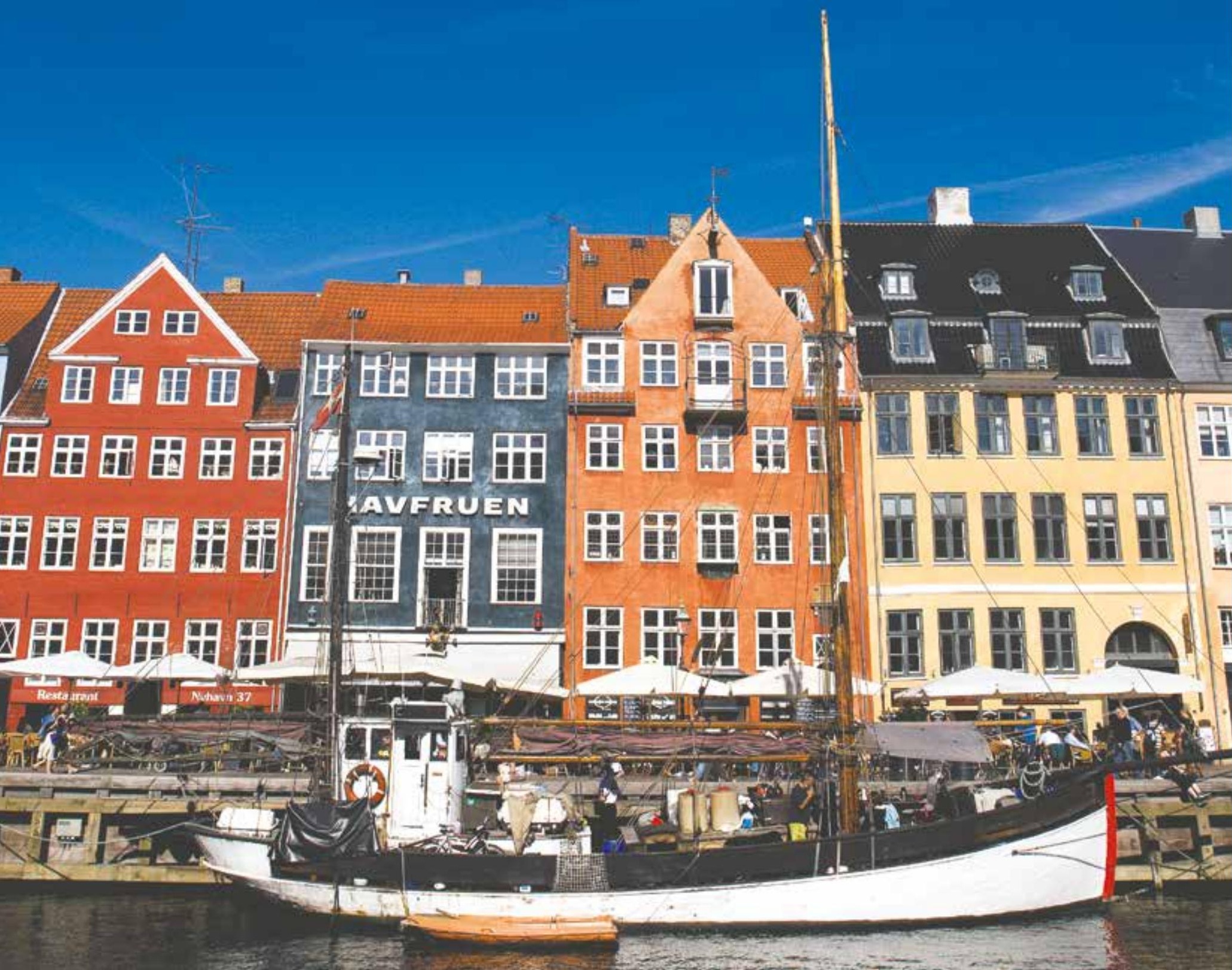




\section{Travlt år - med nye initiativer}

\author{
Grænsehindringsrådet har i 2015 fortsat \\ arbejdet for en stadig bedre information, \\ at fjerne eksisterende hindringer og \\ forebygge at nye hindringer opstår.
}

Samarbejdet med de regionale grænsehindringsaktører og Hallo Norden har også i 2015 været afgørende for vort arbejde. Det er ikke mindst disse aktører, der har den tætte kontakt til borgere og virksomheder, der oplever problemer med regler og lovgivning, når man virker på tværs af de nordiske grænser.

Vækst i Norden har været højt prioritet under det danske formandskab. Samarbejdsministeren nedsatte en arbejdsgruppe med repræsentanter fra erhvervslivet og lønmodtagerne, hvor jeg som formand for Grænsehindringsrådet og vort sekretariat i Ministerrådet har medvirket og bidraget. Arbejdsgruppen offentliggjorde sin rapport på en vækstkonference på Børsen i København den 30. april 2015. Rapporten indeholder 15 konkrete hindringer for vækst og udvikling i Norden. Konferencen blev åbnet af statsminister Helle ThorningSchmidt og konklusionerne blev af gruppen afleveret med brev til alle de nordiske statsministre og regeringslederne for de selvstyrende områder.

Efterfølgende har statsministrene og regeringslederne drøftet arbejdsgruppens henvendelse og besluttet at give "generalsekretæren i Nordisk Ministerråd i opdrag at sikre en struktureret dialog, hvor organisationerne kan mødes med Grænsehindringsrådet og relevante nordiske ministre...”.

Det kommende finske formandskab har signaleret, at man også fra finsk side vil prioritere en tæt dialog med erhvervslivet og arbejdsmarkedets parter. Der er således skabt et godt udgangspunkt for et fremadrettet samarbejde og dialog med nordiske virksomheder og lønmodtagere.

Også i forhold til EU Kommissionen har vi i 2015 skabt en tættere dialog. Ofte kan løsninger på europæisk plan være det bedste svar til også at løse grænsehindringer i Norden. Den 29. september 2015 havde vi i Grænsehindringsrådet besøg af DG Regio, med rundvisning og møde hos European Spallation Source, ESS i Lund om formiddagen og rundbordssamtaler i København om eftermiddagen. Der er enighed om en tættere kontakt og dialog fremover - til glæde for begge parter.

2015 har således været et travlt arbejdsår med tæt opfølgning på det løbende arbejde og med nye initiativer, som kan styrke vækst og udvikling i Norden. Tolv af Grænsehindringsrådets prioriterede hindringer er løst eller afklaret, som det fremgår af nærværende rapport. Informationsarbejdet er styrket og intensiveret. Og Rådet har haft en konstruktiv dialog med formændene for vore nordiske parlamenter for at skabe bedre regler for at undgå nye grænsehindringer. Der skal lyde en stor tak til Grænsehindringsrådets lille, men meget kompetente, engagerede og flittige sekretariat. Der gøres et imponerende arbejde - og altid med godt humør.

Efter 8 år med grænsehindringsarbejdet, har jeg meddelt ministeren, jeg stopper til nytår 2016. Det blev til 6 år i Grænsehindringsforum og to år i Grænsehindringsrådet. Derfor vil jeg tillade mig at slutte med nogle mere personlige konklusioner:

Der er sket markante og mærkbare forbedringer gennem ændret lovgivning og bedre regler og administration. Der er skabt bedre og mere tilgængelige informationer for både personer og virksomheder. Der er meget at glæde sig over.

Alligevel undrer det mig, hvor langsommelig og besværligt det er at ændre uhensigtsmæssige regler. Selv om mange møder opgaven med velvilje, er der endnu flere, som forsøger at finde begrundelser for, at de eksisterende regler er "gode nok". Det er holdninger, der findes i de forskellige "systemer", som kun kan ændres gennem et langt større politisk engagement hos både ministre og parlamentarikere.

Norden har stadig et stort uudnyttet vækstpotentiale, som venter på politisk handling for at blive udløst.

Tak til alle rådets medlemmer for godt samarbejde og et stort engagement. 


\section{Gränshinderrådets medlemmar}

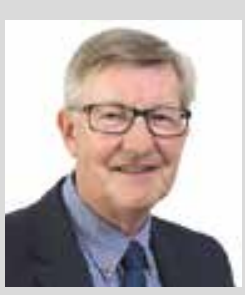

Ole Stavad · Danmark · Ordförande 2015

Jeg vil i det nye Nordiske Grænsehindringsråd arbejde ihærdigt for at afdække problemområder og for at overbevise vore regeringer om værdien af at fjerne grænsehindringer og for et endnu tættere nordisk samarbejde. Norden er det største marked for vore nordiske lande og der er fortsat et stort vækstpotentiale inden for Norden. Det skal vi udnytte. Højere vækst vil skabe flere arbejdspladser og råd til bedre velfærd. Derfor skal vi afskaffe endnu flere grænsehindringer og samarbejde endnu tættere mellem vore nordiske lande.

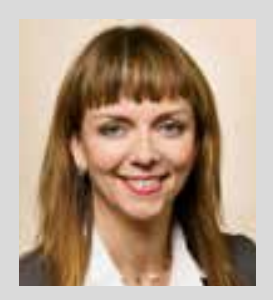

\section{Siv Fridleifsdottir · Island · Ordförande 2014}

Vi lever i tid där människor inom Norden reser mycket mer över nationsgränserna än tidigare. Inom Norden gör vi affärer och arbetar tvärs över gränserna, studerar i ett annat nordiskt land eller flyttar av någon annan orsak. Tidigare accepterades gränshinder som något naturligt, men i en allt mer gränslös värld finner man sig inte i att gränserna utgör hinder. Vi arbetar mot gränshinder och tror att många områden kan förbättras för att öka tillväxten, även om vi samtidigt är medvetna om att Norden inte kan bli helt gränslöst. Statsministrarna har nyligen gett oss i uppgift att utveckla samarbetet med arbetsmarknadens parter för att ta bort gränshinder och öka tillväxten.

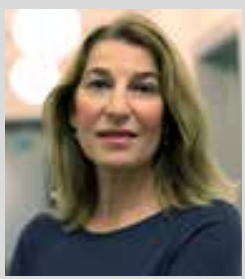

\section{Annika Hahn-Englund · Sverige}

Arbetet med att avskaffa hinder mot tillväxt i Norden har högsta prioritet för den svenska regeringen. Vår vision är ett Norden där människor och företag fritt kan verka över gränserna, obehindrat av nationella regler och bestämmelser.

Gränshinderrådet säkerställer att alla aktörer drar åt samma håll för ett effektivt gränshinderarbete. Ett nära samarbete med fackministerråden, Nordiska rådet och de gränsregionala aktörerna är centralt. 


\section{Marjun Magnussen · Färöarna}

Fra færøsk side har vi meget glade for at deltage i Grænsehindringsrådet, og være med til at få løst grænsehindringer og forebygge, at nye opstår. Borgere og virksomheder virker på tværs af landegrænser, men dette hæmmes af grænsehindringer, og derfor er det så vigtigt at få dem løst.

Den færøske deltagelse i Grænsehindringsrådet synliggør også de udfordringer, der er i forhold til de lande, der er medlemmer af EU eller EøS.

I takt med at flere og flere EU-regler finder vej ind i det nordiske qua landenes medlemskab, er dette med til at skabe flere hindringer for os, der ikke er medlemmer af EU eller EØS og understreger vigtigheden af vores deltagelse i grænsehindringsarbejdet.

Min opfattelse er, at man i højest muligt omfang bør sikre de nordiske overenskomster, hellere end blot at se disse ophævet og erstattet af EU-regler, da disse nordiske overenskomster udover at deres åbenlyse formål, også er vigtige i forhold til den nordiske samhørighed.

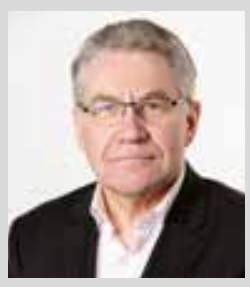

\section{Svein Ludvigsen · Norge}

Arbeidet med å fjerne grensehinder har vist seg å være et tydelig prioritert arbeid i regjeringen og berørte departementer. Samarbeidsminister Elisabeth Aspaker forventer resultater, og grensetjenestene er utålmodig. Derfor er det gledelig å konstatere at flere grensehinder som jeg har hatt ansvar for er løst i løpet av 2015. Embetsverket i departementene har vært positive og løsningsorienterte, og jeg takker alle som har gjort arbeidet mitt enklere. Fortsatt er det uløste hinder som bør løses for å få enda bedre vilkår, for både arbeidstakere og arbeidsgivere, over de nordiske landegrensene. Jeg ser derfor ikke for meg at Grensehinderrådet blir arbeidsledig. Spesielt inspirerende er det at Norge i 2017 skal ha hovedansvaret for dette arbeidet. 


\section{Gränshinderrådets medlemmar}

\section{Sten Palmgren · Finland}

Gränshinderrådet har under sina första två år visat att det finns behov av en samlad nordisk insats för att sätta press på beslutsfattarna att lösa hinder för mobilitet mellan våra länder. Den struktur som har byggts upp och den grund som har lagts ger förhoppning om många konkreta resultat de närmaste åren. De dramatiska händelserna i Europa och dess närområden bara förstärker behovet av ett tätt nordiskt samarbete.

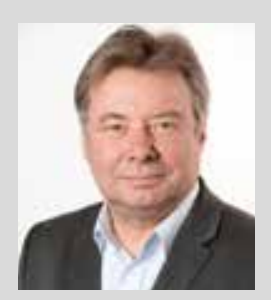

\section{Gunnar Westerholm · Åland}

Mina förväntningar på Gränshinderrådet är att även det arbete som redan utförts följs upp och leder till resultat. Förhoppningen är också att Gränshinderrådet kan upprätthålla en auktoritet mot ministerier och myndigheter så att gränshinderarbetet prioriteras på alla nivåer. Informationens tillgänglighet måste lyftas fram som en faktor för att minska antalet drabbade. Ett gränshinder är, oavsett hur många som drabbas, ett hinder för mycket.

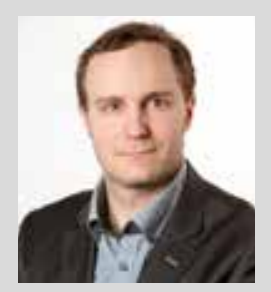

\section{Christian Wennecke · Grönland}

I Grønland er til- og fra-flytningen så stor, at knap 5 \% af befolkningen "skiftes ud" hvert år. Grænsehindringer påvirker altså potentielt en ret stor andel af befolkningen. Vi forventer at der vil komme ukendte grænsehindringer frem i lyset, og at vi gennem arbejdet i Grænsehindringsrådet kan gøre livet nemmere for mange grønlændere og grønlandske virksomheder. 


\section{Dagfinn Høybråten · Nordiska ministerrådet}

Grensehindringsrådet har en unik sammensetning av folk med tung politisk, faglig og administrativ bakgrunn. Jeg har stor tro på at vi sammen kan løse flere grensehindringer i samspill med dem som lager lover og regler i de nordiske land. Som ledd i Moderniseringsreformen Nytt Norden arbeides det nå mer målrettet med EU-saker i fagministerrådene. Det gir økt felles nordisk aktivitet både i utforming og implementering av regelverk som har betydning for mobiliteten mellom landene. En stor utfordring framover blir å sikre at den nye situasjon med $ø$ kt migrasjon ikke bidrar til en generell svekkelse av Norden som en sammenhengende region, men at vi fortsatt kan tenke innovativt sammen om løsninger som møter fremtidens behov. Et grenseløst Norden der innbyggerne behandles mest mulig likt og kan bevege seg fritt over landegrensene har alltid vært en bærende ide for det nordiske samarbeidet.

\section{Marit Nybakk · Nordiska rådet}

Fjerning av grensehindre i Norden og det å hindre nye, er fortsatt noe av det viktigste arbeidet landene imellom. Dette må også ses innenfor en EU/EØS-ramme og EUs indre marked, slik at vi ikke får nye grensehindre som følge av ulik implementering av direktiv. Et velfungerende nordisk arbeidsmarked er særlig avhengig av at nordiske arbeidstakere ikke støter på grensehindre som svekker mobilitetene mellom landene. Jeg har stor tro på at Grensehinderrådet kan bidra til gode innspill, tett oppfølging og påtrykk, slik at nasjonale myndigheter fjerner grensehindre til beste for Nordens innbyggere. 


\section{Innehållsförteckning}

5 Statsministerdeklaration

7 Förord: Travlt år - med nye initiativer

8 Gränshinderrådets medlemmar

13 Innehållsförteckning

14 Organisering av Gränshinderrådets arbete

16 Gränshinderrådets mål

18 Status över 2015 års prioriterade gränshinder

21 Hinder på arbetsmarknadsområdet

31 Hinder på utbildningsområdet

47 Hinder på socialförsäkringsområdet

63 Hinder på skatteområdet

81 Hinder på näringslivsområdet

91 Övriga gränshinder

100 Akuta gränshinder

102 Avklarade gränshinder under 2014

104 Involvering av arbetsmarknadens parter

105 Erklæring fra de nordiske statsministre vedrørende vækst- og grænsehindringer i Norden

107 Nordiska Rådets Gränshindergrupp

108 Informationsarbetet

110 Det förebyggande arbetet

112 Efterord 


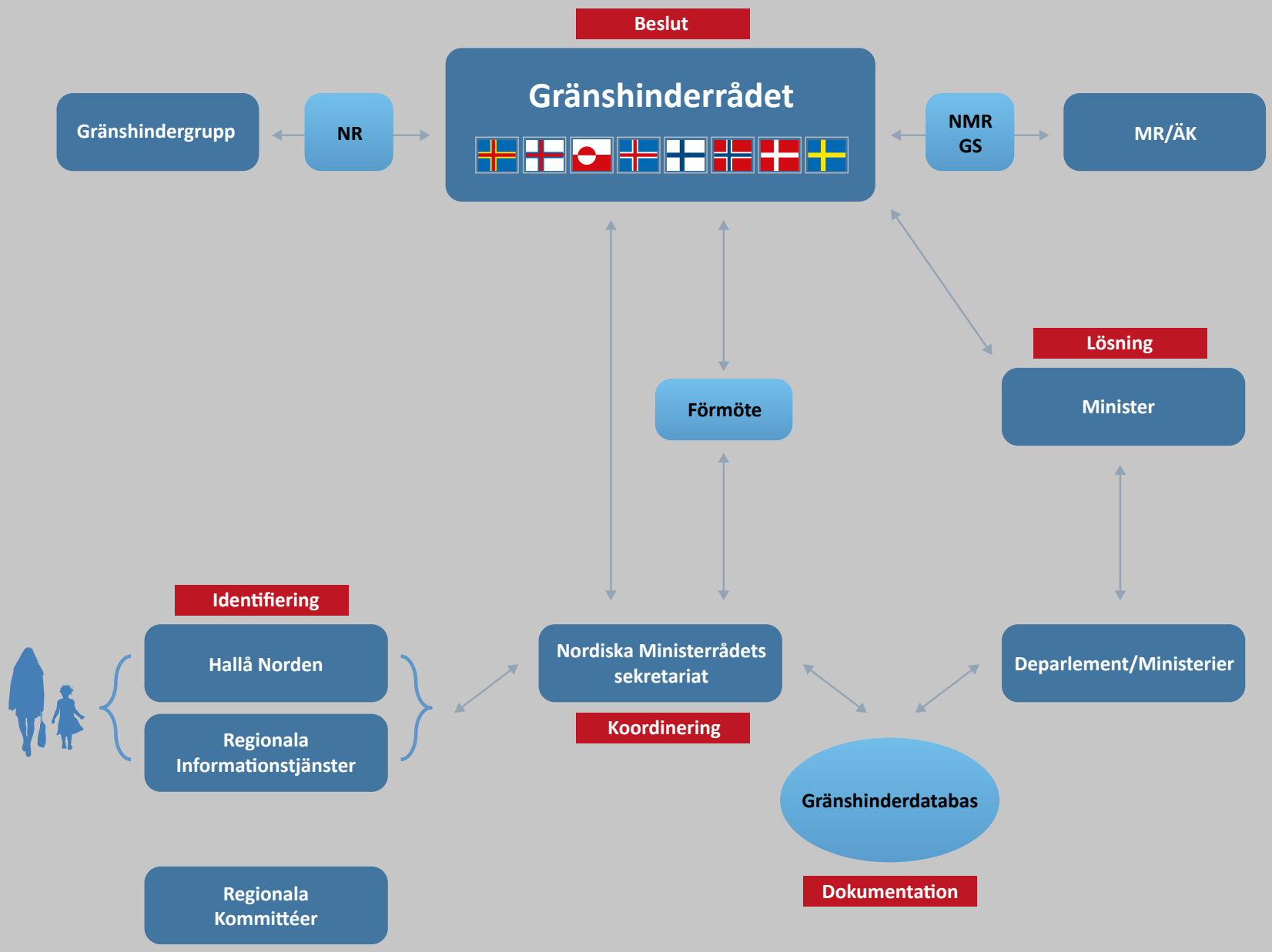




\section{Organisering av Gränshinderrådets arbete}

För att skapa transparens och delaktighet hos medborgare, företag och problemägare är det viktigt att skapa en tydlig koppling mellan de identifierade gränshindren och Gränshinderrådets arbete till berörda departement/ministerier, ministerråd och parlament.

Illustrationen ger en bild av hur Gränshinderrådets arbete är organiserat.

\section{Identifiering}

Gränshinder identifieras där medborgare och företag söker information om att förflytta sig över de nordiska gränserna. För att möta medborgarnas informationsbehov har man i Norden utvecklat de regionala informationstjänsterna Øresunddirekt, Grensetjänsten Sverige/ Norge och Nordkalottens Grenstjenst. Därutöver finns även den nordiska informationstjänsten Hallå Norden som är placerad i de nordiska huvudstäderna. Här sker identifiering av hinder via webb, e-post, telefon, personlig betjäning samt informationsträffar.

\section{Koordinering}

Informationstjänsternas identifierade hinder skickas vidare till Gränshinderrådets sekretariat där de dokumenteras i den gemensamma nordiska gränshinderdatabasen. Sekretariatet ansvarar också för att koordinera Gränshinderrådets arbete och återkopplar löpande till informationstjänsterna. Sekretariatet ansvarar också för att utveckla och implementera en gemensam handlingsplan för informationstjänsterna i syfte att öka samarbetet och effektivisera gränshinder- och informationsarbetet.

\section{Dokumentation}

Samtliga identifierade gränshinder dokumenteras i gränshinderdatabasen. Berörda departement kvalitetssäkrar innehållet i databasen.

\section{Beslut}

Baserat på de hinder som finns identifierade i gränshinderdatabasen beslutar respektive medlem i Gränshinderrådet vilka gränshinder man kommer att prioritera. Varje nationell medlem prioriterar 3-5 hinder. De nationella medlemmarna uppvaktar berörda departement och ministrar tills svar ges. Svaret kan antingen vara att departementet/ministeriet finner en lösning eller att man beslutat att inte gå vidare med att lösa det. Svaren från de berörda departementen/ministerierna redovisas årligen i Gränshinderrådets årsrapport. På så sätt kan man följa processen kring de prioriterade hindren.
Nordiska ministerrådets representant koordinerar information mellan Gränshinderrådets arbete och de berörda ministerråd som prioriterat samma hinder som Gränshinderrådet. Nordiska rådets representant i Gränshinderrådet kan genom parlamentarikerna i Nordiska rådet lyfta de prioriterade gränshindren i de nordiska parlamenten.

\section{Lösning}

Det är bara hos de berörda departementen en lösning på de identifierade hindren kan ske. Gränshinderrådet kan däremot bidra till att synliggöra gränshinder för medborgare och företag som hämmar mobilitet och tillväxt $\mathbf{i}$ Norden. Detta görs genom att ge en tydlig problembeskrivning, förslag till lösning samt kostnadsanalys av vad gränshindret kostar medborgaren och/ eller företaget i den mån det är möjligt att ta fram. Gränshinderrådets syfte är att följa statsministerdeklarationen vad gäller gränshinder i Norden. Därför är samarbetet och den öppna dialogen med berörda departement av stor betydelse för arbetet. 


\section{Gränshinderrådets mål}

Gränshinderrådet bör rent principiellt prioritera att arbeta med de frågor som inkommer via gräsrötterna, det vill säga: Hallå Norden, Grensetjänsten, Øresunddirekt/Öresundskomiteen, Nordkalottrådet och de olika myndigheterna.

Gränshinderrådet ska främst prioritera gränshinder som uppkommer inom arbetsmarknad, social- och utbildningsområdet och som är möjliga att förändra genom avtal och regeländringar.

Målet är att få 5-10 nordiska gränshinder per år avklarade som resultat av Gränshinderrådets arbete. För att skapa långsiktighet och struktur i gränshinderarbetet bör varje medlem i Gränshinderrådet i samråd med nationella aktörer, årligen välja ut 3-5 gränshinder som skall ha högsta prioritet.

De utvalda gränshindren kommer under året att vara särskilt prioriterade och Gränshinderrådet ska driva dem tills svar avgivits från berörda departement och myndigheter. Har ingen lösning avgivits under innevarande år fortsätter dessa gränshinder att vara prioriterade fram till dess svar från berörda departement och myndigheter avgivits.

\section{Nytt för 2015}

- Gränshinderrådets medlemmar samarbetar kring ett antal prioriterade hinder för att ömsesidigt förankra gränshinderprocessen i de fall där det krävs.

- Fyra operativa möten per år med där fokus främst ligger på statusrapportering och feedback om de prioriterade gränshindren. Inför rådets möten håller några av medlemmarna förmöten med relevanta departementstjänstemän samt representanter från både de nordiska och de gränsregionala informationstjänsterna och kommittéerna.

- Medlemmarna har även möjlighet att hålla arbetsmöten dagen före och efter ordinarie gränshinderrådsmöte. En möteslokal på Nordiska Ministerrådet i Köpenhamn ställs till förfogande och sekretariatet finns även att tillgå.

- Gränshinderrådet håller även ett årligt kickoffmöte där man utvärderar förra årets gränshinderarbete och utifrån detta vidareutvecklar sina arbetsmetoder. 


\section{Prioriterade gränshinder}

Gränshinderrådets medlemmar har var och en eller i vissa fall gemensamt valt att prioritera 3-5 gränshinder.

Gränshinderrådets prioriteringar av gränshinder har gjorts vid två tillfällen. Dels den 11 april 2014, då den första prioriteringslistan beslutades av Gränshinderrådets medlemmar, dels den 16 april 2015 då listan kompletterades med nya prioriterade hinder.

Gränshinderrådets medlemmar har graderat arbetet med sina prioriterade hinder enligt en färgskala med fyra nivåer.

Blått betyder att ett slutligt svar har kommit från berörda departement. Av färgstämpeln framgår om hindret faktiskt blivit löst eller om länderna beslutat att avskriva hindret och inte arbetar vidare för att hitta en lösning.

Grönt innebär att arbetet följer den process som respektive medlem satt upp för att få ett slutligt svar på huruvida hindret kommer att lösas eller inte.

Gult betyder det pågår någon form av arbete med hindret vid berörda departement/ministerier.

Rött innebär att hindret för närvarande inte är prioriterat vid berörda departement, ministerier eller myndigheter.
Årsrapporten 2015 är en status över de hinder som prioriterats av respektive medlem i Gränshinderrådet.

Det är viktigt att notera att hindren är i process och därmed kan deras status vara annorlunda vid tidpunkten för läsandet. Det kan dessutom finnas andra bedömningar av de prioriterade hindren från de nordiska länderna än vad som anges av Gränshinderrådets medlemmar.

\section{Om beräkningarna}

Vid beräkningen av kostnaderna har vi så långt det har varit möjligt använt oss av befintlig statistik. I de fall ingen statistik har funnits har vi gjort uppskattningar utgående från existerande statistiska uppgifter. I enskilda fall har vi varit tvungna att göra antaganden för att kunna illustrera kostnaderna. I de fallen nämns detta skilt i samband med beräkningarna. 


\section{Status över 2015 års prioriterade gränshinder}

Arbetsmarknad

Arbetsrehabilitering i bosättningslandet

Rätt till tjänstledighet för politiskt uppdrag i annat nordiskt land

Anmälan till fel A-kassa kan medföra förlorad rätt till ersättning

Långa handläggningstider (i EU-ärenden)
Status Prioriterat av

$\mathrm{SE} / \mathrm{DK}$

$\mathrm{SE} / \mathrm{DK}$

SE

IS/NO

\section{Utbildning}

Status Prioriterat av

Ingen rätt till studiestöd efter arbete utomlands

FI/AX

EU:s mobilitetsprogram

SE/IS

Erkännande av yrkeskvalifikationer

Vuxenutbildningsstöd till löntagare som blir studieledig

SE/IS

Godkännande av grönländska utbildningar

$\mathrm{FI}$

$\mathrm{GL}$

Öresundskommittén anser att det finns hinder för danska ungdomar att få praktikplats i Sverige

\begin{tabular}{lcc} 
Socialförsäkring & Status & Prioriterat av \\
\hline Den norska faderskvoten & & NO \\
Studerandes socialförsäkring i ett annat nordiskt land & DK \\
Sjukersättning patientresa mellan Norge och Finland/Sverige & FI/NO \\
Krav på att omfattas av olika länders arbetslöshetsförsäkring utan & SE \\
avbrott för att inte riskera lägre arbetslöshetsersättning & \\
Finska fyramånadersregeln & $\mathrm{FI}$ \\
Flytt för institutionaliserade personer & $\mathrm{DK}$
\end{tabular}


Dubbelbeskattning Grönland och Sverige/Finland $\mathrm{GL}$

Beskattning av dansk kapitalpension

$\mathrm{GL}$
$\mathrm{DK}$
$\mathrm{NO} / \mathrm{SE}$
$\mathrm{DK}$
$\mathrm{DK}$
$\mathrm{NO} / \mathrm{DK}$
$\mathrm{SE} / \mathrm{DK}$
$\mathrm{FO} / \mathrm{NO}$

Rutiner för skatteinbetalning för äkta gränsgångare

Problem med fast anställda kulturarbetare i Sverige

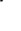

Frågor om dubbelbeskattningsavtalet i förhållande till studiestöd

$\mathrm{DK}$

Norsk intern skattepraxis försvårar utförande av uppdrag i byggbranschen

Beskattning av utländska pensioner i bosättningslandet

$\mathrm{FO} / \mathrm{NO}$

Skatteavdrag för färöiska studenter i Norge

Status Prioriterat av

Erläggande av mervärdeskatt vid överförande av arbetsmaskin

SE

från Norge till Sverige

Färöiska färdskrivarkort

FO

Norska tull- och momsregler för nordiska företag

NO

Olika byggbestämmelser

$\mathrm{Fl} / \mathrm{AX}$

Eltariffer för Åland

$\mathrm{Fl} / \mathrm{AX}$

Övrigt

Status Prioriterat av

Samordningsnummer till utländska fritidshusägare i Sverige SE

Gränsregional statistik $\mathrm{FI}$

Erkännande av färöiska körkort FO

Grönländska körkort

$\mathrm{GL}$

Akuta

Status

Arjeplogavtalet

Finskt krav på säkerhet vid tillfällig import av husvagnar, skotrar, etc 


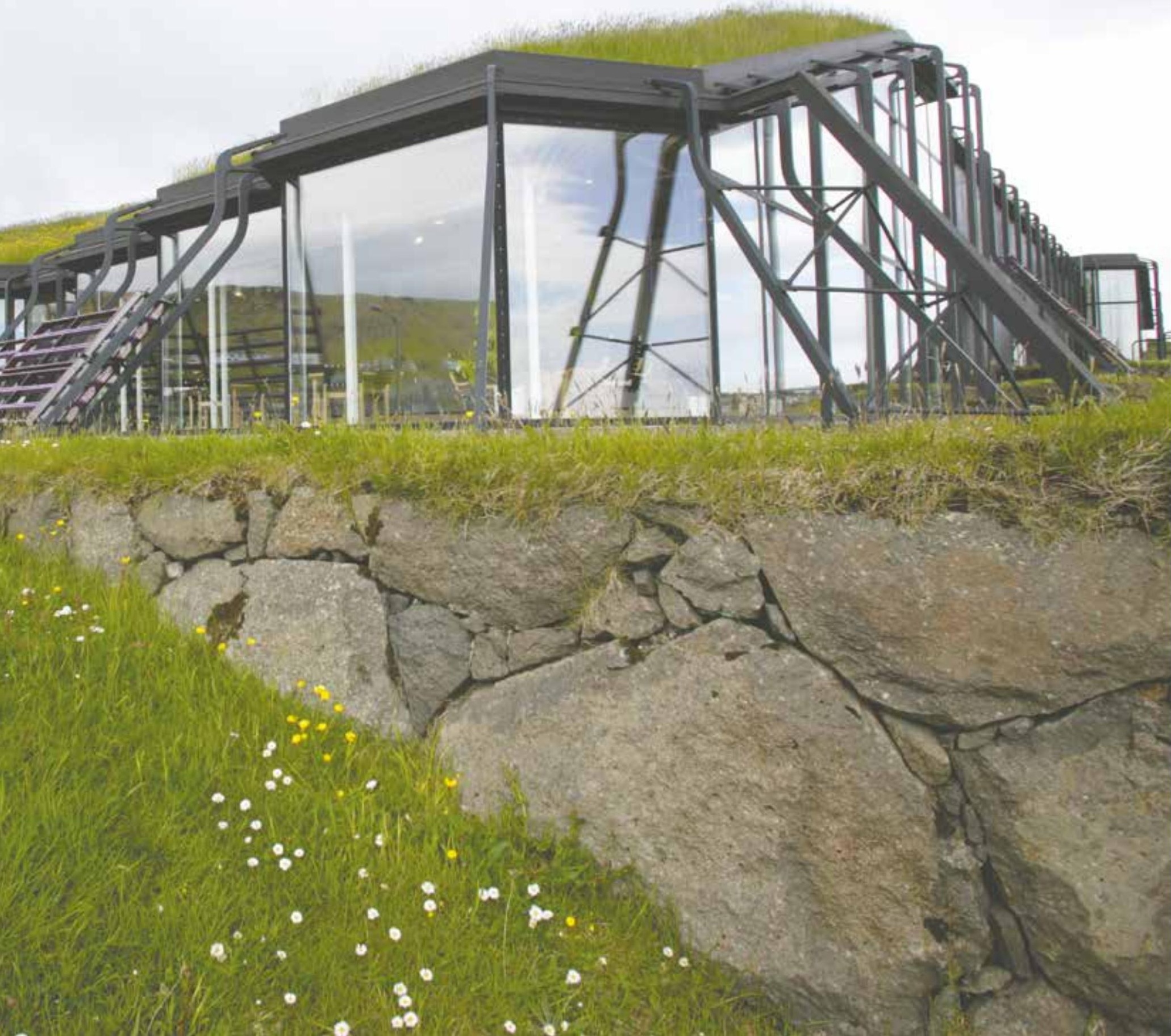




\section{Hinder på arbetsmarknadsområdet}




\title{
Arbetsrehabilitering i bosättningslandet
}

\author{
En person som bor i ett land, arbetar i ett annat land och blir skadad eller på \\ annat sätt oförmögen att arbeta under längre tid, kan ha svårt att få arbets- \\ relaterad rehabilitering i bosättningslandet efter den medicinska behandlingen. \\ Det betyder att personen kan behöva resa dagligen till arbetslandet för att \\ genomgå rehabilitering, vilket kan vara mycket belastande för en sjuk person.
}

Ett prioriterat gränshinder av Annika Hahn Englund, Sverige och Ole Stavad, Danmark. Även prioriterat av MR-S. Hindret kan lösas genom bilaterala avtal mellan länderna.

Prioriterat sedan 2015

\section{Bakgrund}

Problemet regleras i den nya nordiska konventionen om social trygghet som trädde i kraft 1 maj 2014. Detta följer av konventionens artikel 12, där det fastslås att länderna ska ingå avtal som kan säkerställa att problemen löses för enskilda berörda. De bilaterala avtal mellan de administrativa myndigheterna som skulle ingås två år från ikraftträdandet är nu på plats.

Enligt EU-förordningarna 1408/71 och $883 / 2004$ faller rehabilitering under "Förmåner vid sjukdom, moderskapsoch likvärdiga faderskapsförmåner". När det är fråga om en person som bor i (eller flyttar tillbaka till) ett annat land än det land vars lagstiftning tillämpas på honom eller henne, gäller det att arbetslandet är ansvarigt för kontantförmåner (det vill säga rehabiliteringspenning, sjukdagpenning, etc.) medan bosättningslandet är ansvarigt för vårdförmåner. När det är fråga om rehabilitering omfattar vårdförmåner rehabiliteringsåtgärder, arbetsträning, utbildning och så vidare.

I praktiken är det ytterst svårt att tillämpa dessa bestämmelser, även om EU-rätten är överordnad de nationella lagstiftningarna. Orsaken är dels att ländernas lagstiftningar ofta är mycket olika, dels att samordning mellan kontant- och vårdförmåner vid rehabilitering kan vara komplicerat redan på nationell nivå. Därutöver finns det svårigheter orsakade av förändringar $i$ ländernas lagstiftning i tillämpningen av EU:s förordningar i fall där personer arbetar över de nordiska gränserna. Ett exempel är att den svenska sjukförsäkringsreformen har skapat problem för personer som arbetar eller senast arbetade i Sverige men bor i ett annat nordiskt land.

Gränshindret motsvaras av nr B5 i rapporten "Gränshinder i Norden på social- och arbetsmarknadsområdet" (Nord 2012:002).

\section{Vem påverkas}

Nordiska medborgare som är bosatta i ett nordiskt land men jobbar i ett annat och är i behov av arbetsrehabilitering.

\section{Förslag till lösning}

En nordisk expertgrupp har i rapporten Nord 2012:002 slagit fast att det är viktigt att behöriga institutioner och 


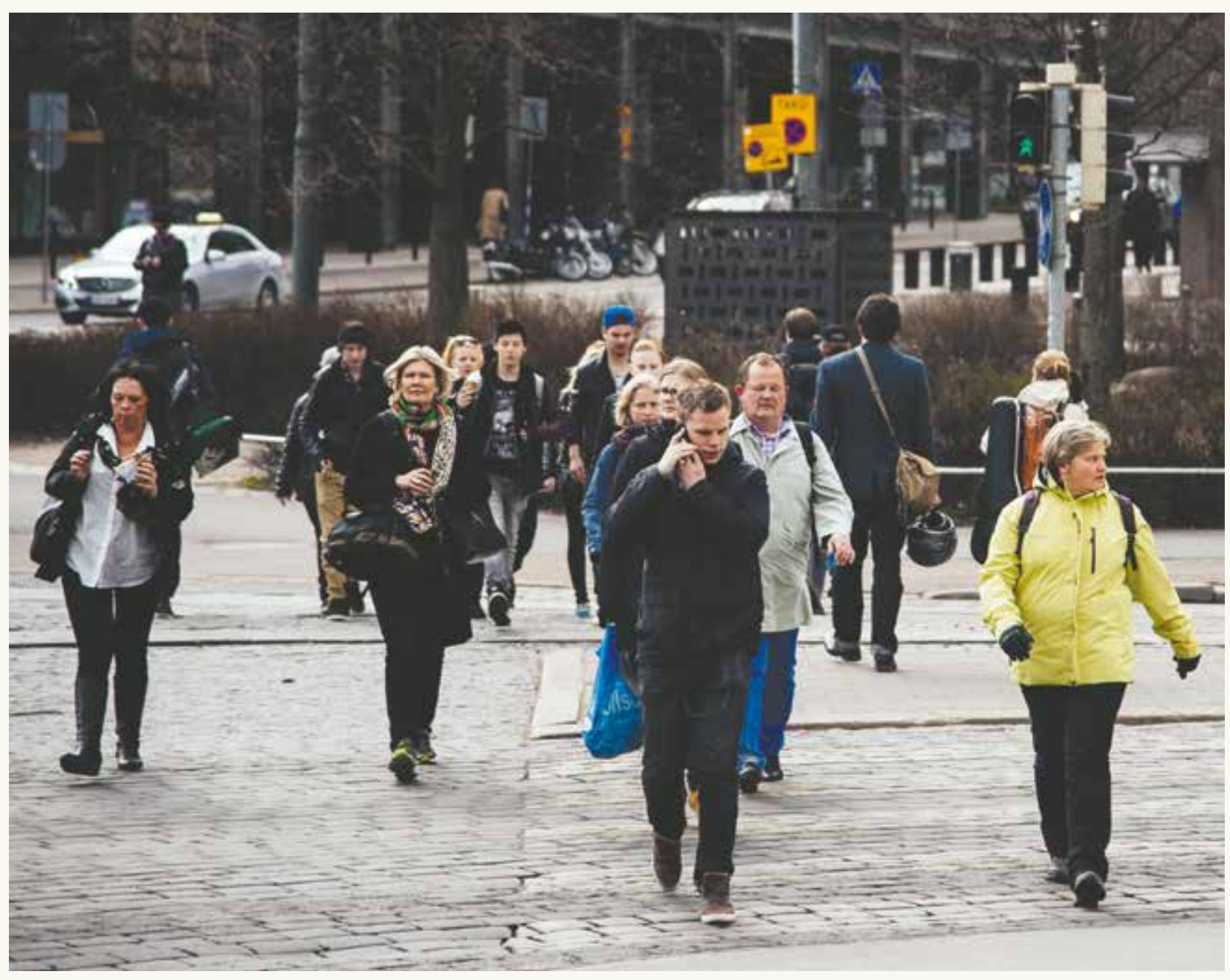

handläggare får kännedom om att man enligt EU-förordningarna har rätt till att få åtgärder i sitt bosättningsland och samtidigt kontantförmåner från det tidigare arbetslandet. Gruppen efterfrågar också förtydliganden om vad olika nationella begrepp och förmåner innebär. Dessutom fastslås det att Nordiska rehabiliteringsgruppen bör arbeta vidare med bilaterala överenskommelser om rehabilitering, vilka behövs oberoende av om den nya konventionen undertecknas eller inte.

\section{Gränshinderrådets arbete med frågan/kommentarer från berörda regeringar}

Socialdepartementet, SE och

Ole Stavad, DK:

Avtalen förhandlades mellan förbindelseorganen i de nordiska länderna och har börjat tillämpas.
Läs mer i Gränshinderdatabasen, granshinder.norden.org, gränshinder nr: 14-014. 


\title{
Rätt till tjänstledighet för politiskt uppdrag från arbete i annat nordiskt land
}

\author{
Den som bor i ett nordiskt land och arbetar i ett annat har inte rätt till \\ tjänstledighet för politiska uppdrag i bosättningslandet. Detta kan \\ vara ett hinder för att ta politiska uppdrag.
}

Ett prioriterat hinder av Annika Hahn-Englund, Sverige och Ole Stavad, Danmark.

Hindret finns med i det danska avtalet mellan Folketinget och regeringen.

Nordiska ministerrådets sekretariat samt berörda ministerier har arbetat med detta gränshinder.

\section{Bakgrund}

I de nordiska länderna finns regler om att förtroendevalda har rätt att få tjänstledigt från arbetet för att fullgöra politiskt uppdrag som de har valts till. Denna rätt gäller endast om personen bor, arbetar och utför politiska uppdrag i samma land. En gränsarbetare som blir förtroendevald $i$ sitt bosättningsland har således inte motsvarande rätt till tjänstledighet i sitt arbetsland för att utföra sitt politiska uppdrag i bosättningslandet.

\section{Vem påverkas}

Detta hinder berör främst de personer som har politiskt uppdrag inom den grupp som daglig-/veckopendlar över en nationsgräns.

Hindret begränsar dessutom rätten till tjänstledighet för politiska uppdrag för de som daglig-/veckopendlar över en nationsgräns vilket totalt är cirka 70000 personer.

\section{Förslag till lösning}

En gränsarbetare som är förtroendevald i bosättningslandet skulle eventuellt genom att de nationella reglerna skrivs om för att även gälla personer med arbete i landet och politiskt uppdrag i grannlandet eller genom bilaterala avtal, ges rätt att få tjänstledighet för att fullgöra politiska uppdrag i bosättningslandet utifrån arbetslandets tjänstledighetsregler.

\section{Gränshinderrådets arbete med frågan/kommentarer från berörda regeringar \\ Finansdepartementet, SE:}

Enligt överenskommelse på tjänstemannanivå ska DK ta fram ett första utkast till bilateralt avtal mellan SE och DK angående ömsesidigt erkännande av tjänstledighetsreglerna. SE avvaktar att DK återkommer i frågan.

\section{Ole Stavad, DK:}

Det danske Folketing vedtog den 19. februar 2015 ministerens lovforslag, som bemyndiger ministeren til under forudsætning af gensidighed - at indgå aftale med et andet land, hvorefter personer som varetager kommunalpolitiske eller regionalpolitiske hverv $\mathbf{i}$ det pågældende land, kan opnå ret til fravær fra arbejdet i Danmark, efter de samme regler som gælder for ansatte bosiddende i Danmark. Ministeren har klart tilkendegivet, at man fra dansk side ønsker at indgå sådanne aftaler med de øvrige nordiske lande.

Läs mer i Gränshinderdatabasen, www.norden.org gränshinder nr: 14-132. 


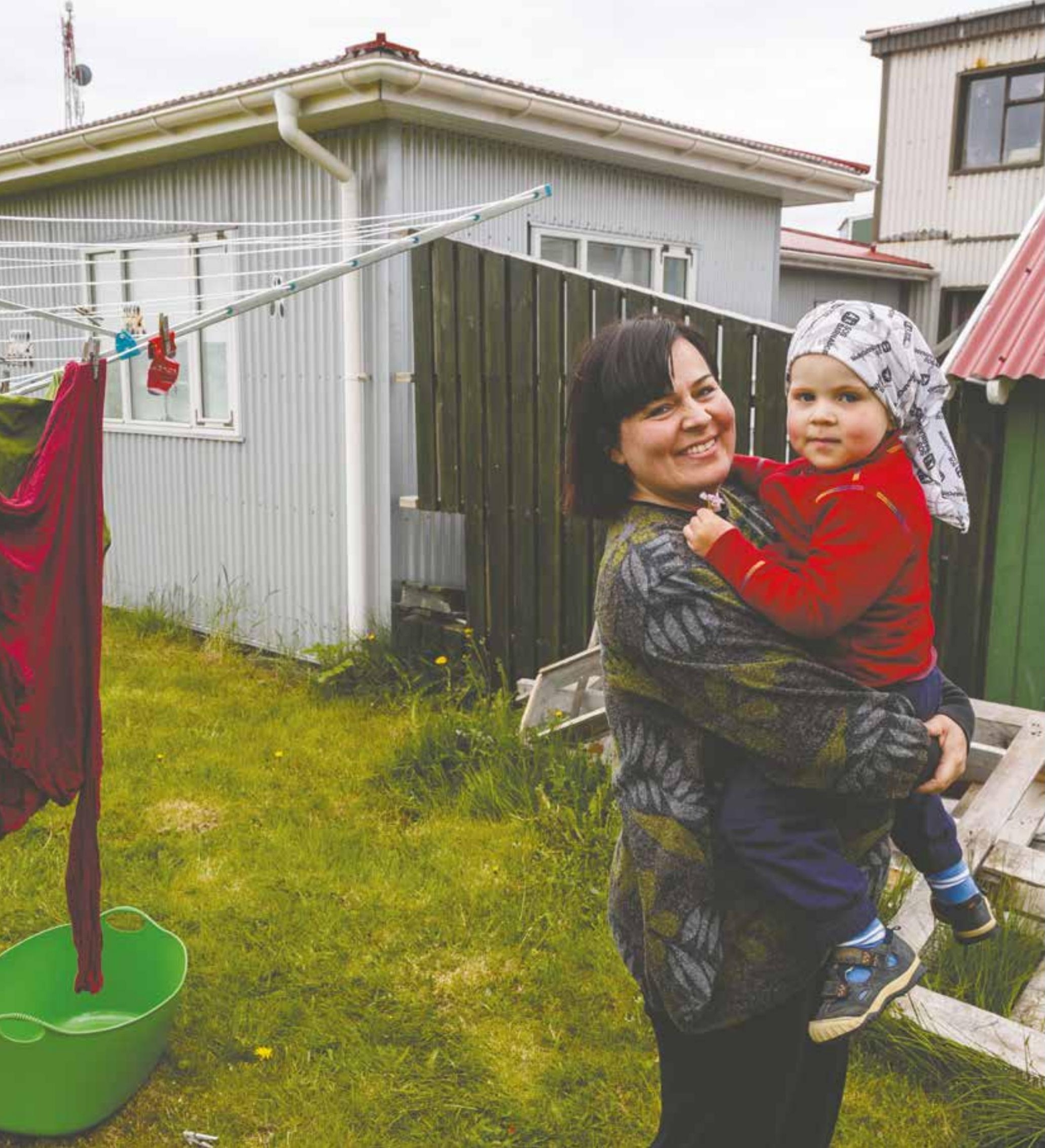




\section{Anmälan till fel A-kassa kan medföra förlorad rätt till ersättning}

\section{Personer som blir arbetslösa kan förlora rätten till inkomstrelaterad ersättning om de ansöker om medlemskap i fel a-kassa. Hindret kan drabba både gränsarbetare men också personer som bott och arbetat i Sverige.}

Ett prioriterat gränshinder av Annika Hahn-Englund, Sverige. Även prioriterat av MR-A.

Hindret kan lösas av Arbetsmarknadsdepartementet.

Prioriterat sedan 2014

\section{Bakgrund}

För en gränsarbetare bosatt i Sverige som arbetar i Danmark gäller arbetslandets lagstiftning avseende den sociala tryggheten under tiden för arbete. $\mathrm{Om}$ personen blir helt arbetslös gäller i stället bosättningslandets lagstiftning. För att erhålla inkomstbortfallsförsäkring från den svenska arbetslöshetsförsäkringen krävs enligt praxis medlemskap i svensk arbetslöshetskassa under en obruten tolvmånadersperiod. Personen kan tillgodoräkna sig försäkringsperioder från tiden i Danmark som då likställs med medlemskap i svensk arbetslöshetskassa.

Problem kan uppstå vid övergången från arbetslandets arbetslöshetsförsäkring till bosättningslandets arbetslöshetsförsäkring. För att i Sverige få tillgång till inkomstbortfallsförsäkringen krävs medlemskap i en svensk arbetslöshetskassa. Om en gränsarbe- tare eller annan person återvänder till Sverige efter arbete inom EU/EES måste han eller hon ansöka om medlemskap $i$ en svensk arbetslöshetskassa omedelbart i samband med övergången mellan länderna. Enligt Inspektionen för arbetslöshetsförsäkringens, IAF, föreskrift (IAFFS 2015:1) ska inträde begäras i den a-kassa inom den bransch gränsarbetaren har arbetat i det andra medlemslandet. Om personen inte ansöker direkt kan ett avbrott i den pågående perioden uppkomma. Det är avbrottet i medlemskapet som är orsaken till att personen förlorar rätten till ersättning från inkomstbortfallsförsäkringen, inte att anmälan gjorts till fel a-kassa.

Det händer att gränsarbetaren ansöker om inträde i "fel" svensk a-kassa. Ofta vill man gå tillbaka till sin gamla a-kassa, men om man har arbetat i en annan bransch i utlandet är det inte möjligt att få inträde som gränsarbe- tare i den gamla a-kassan. Skickas inträdesansökan till fel a-kassa och den a-kassan hänvisar personen till en annan a-kassa, får den sökande inte ta med sig datumet för den ursprungliga inträdesansökan när inträde beviljas till den rätta a-kassan. Istället gäller ansökningsdatumet till den rätta a-kassan vilket kan få till följd att det uppstår ett glapp i försäkringsperioden. Detta kan i sin tur medföra att den sökande mister rätten till inkomstrelaterad ersättning och gränsarbetaren kan då enbart få ersättning enligt grundförsäkringen.

Hindret kan även uppkomma för personer som bor och arbetar i Sverige och måste byta arbetslöshetskassa med anledning av nytt arbete.

\section{Vem påverkas}

Gränspendlare bosatta i Sverige som nyligen blivit helt arbetslösa och söker arbetslöshetsersättning i Sverige. Även 
personer som bott och arbetat i Sverige kan drabbas av ett avbrott vid byte av medlemskap från en a-kassa till en annan ifall det uppstår ett uppehåll $\mathrm{i}$ medlemskapet.

\section{Ekonomiska konsekvenser}

Johan bor i Sverige och arbetar i Danmark, har en lön på 30000 DKK i månaden och betalar varje månad in 443 DKK till sin danska a-kassa. Johan blir helt arbetslös och ska då anmäla sig till den svenska a-kassan. Tyvärr anmäler han sig till fel a-kassa i Sverige. När Johan anmäler sig till rätt a-kassa kommer han att kunna bli medlem. Om det har uppstått ett glapp i försäkringsperioden kommer Johan inte att få ersättning från inkomstförsäkringen.
Det betyder att Johan inte kan få den maximala a-kassa på 20020 SEK som han är berättigad till utan endast en grundersättning på 8030 före och ca 6200 efter skatt. Han går således miste om 11990 per månad.

\section{Förslag till lösning}

Inför 4-veckorsregel för personer som ansöker medlemskap i svensk a-kassa. Det betyder att man ger både den som ansöker om medlemskap och a-kassorna möjlighet att under dessa fyra veckor finna rätt a-kassa åt den arbetssökande utan att personen ifråga blir utförsäkrad på grund av en bruten 12 månadsperiod.

\section{Gränshinderrådets arbete med frågan/kommentarer från berörda regeringar}

Arbetsmarknadsdepartementet, SE:

Arbetsmarknadsdepartementet i Sverige håller på att följa upp resultatet från den parlamentariska socialförsäkringsutredningens slutbetänkande.

Läs mer i Gränshinderdatabasen, granshinder.norden.org, gränshinder nr: $14-150$ 


\section{Långa handläggningstider (i EU-ärenden)}

\section{I de nordiska länderna varierar handläggningstiden för att besluta \\ om social- och arbetslöshetsförsäkringsförmåner. I EU-ärenden kan \\ handläggningstiden bli längre eftersom behörig institution kan behöva \\ hämta in uppgifter från motsvarande institution i ett annat land. \\ Detta kan ge försörjningssvårigheter för den enskilde}

Ett prioriterat gränshinder av Svein Ludvigsen, Norge och Siv Fridleifsdóttir, Island.

Även prioriterat av MR-A.

Hindret kan lösas av handläggande myndigheter i samtliga nordiska länder och självstyrande områden.

Prioriterat sedan 2014

Då detta område omfattar många länder och många olika försäkringsområden så kan inte samtliga gränshinder inom detta område lösas samtidigt. Gränshinderhinderrådet fortsätter bevakning av handläggningstider inom gällande områden.

Generellt för de nordiska länderna vad gäller handläggningstiden för att besluta om social- och arbetslöshetsförsäkringsförmåner

Löst

Handläggningstiden inom socialförsäkringsområdet i Norge 


\section{Bakgrund}

Hindret har kartlagts i rapporten "Gränshinder i Norden på social- och arbetsmarknadsområdet" (Nord 2012:002). Kartläggningen omfattade ärenden med EU-rättslig koppling, bland annat ansökningar om arbetslöshets- och familjeförmåner, pensioner och sjukdagpenningar.

Rapporten visar att handläggningstiderna ofta är betydligt längre då sökanden bott och/eller arbetat utomlands jämfört med då sökanden hållit sig inom hemlandets gränser. Orsaken till de långa handläggningstiderna är att de nationella myndigheterna måste samla in information om sökandens arbetsoch försäkringsförhållanden från sina utländska myndighetskolleger för att kunna avgöra ärendet.

Trots att det finns klara EU-regler som förpliktigar medlemsstaternas myndigheter att samarbeta, så finns det brister i informationsflödet dem emellan. Konsekvensen är att handläggningstiderna förlängs, något som resulterar i att gränsgångare tvingas leva i långa perioder av ovisshet och att de i värsta fall kan råka ut för försörjningssvårigheter.

\section{Vem påverkas}

Detta hinder berör i första hand de personer som arbetar eller har arbetat $i$ ett land och bor i ett annat och ansöker om en arbetslöshets-, sjukförsäkrings-, pensions- eller föräldraförmån. Främst rör det sig om personer som dagligen pendlar över en nationsgräns.

\section{Förslag till lösning}

Tre lösningsförslag:

1. Gemensamma rutiner för handläggning.

2. Fler personalresurser.

3. Möjlighet till att följa handläggningsprocessen.

\section{Gränshinderrådets arbete med frågan/kommentarer från berörda regeringar}

Arbeids- og Sosialdepartementet og Arbeids- og velferdsforvaltningen (NAV) har iverksatt nye rutiner og omorganisering som har redusert saksbehandlingstiden i Norge. På enkelte områder er den halvert. Med det fokus myndighetene har på dette, og under hensyn til at "lang saksbehandlingstid" er en subjektiv opplevelse så kan grensehinderet anses som løst på disse områder.

\section{Socialdepartementet, SE:}

Vad gäller långa handläggningstider planeras det en konferens i regi av Nordiska Ministerrådet i Finland nästa år.

Läs mer i Gränshinderdatabasen, granshinder.norden.org, gränshinder nr: 14-042. 


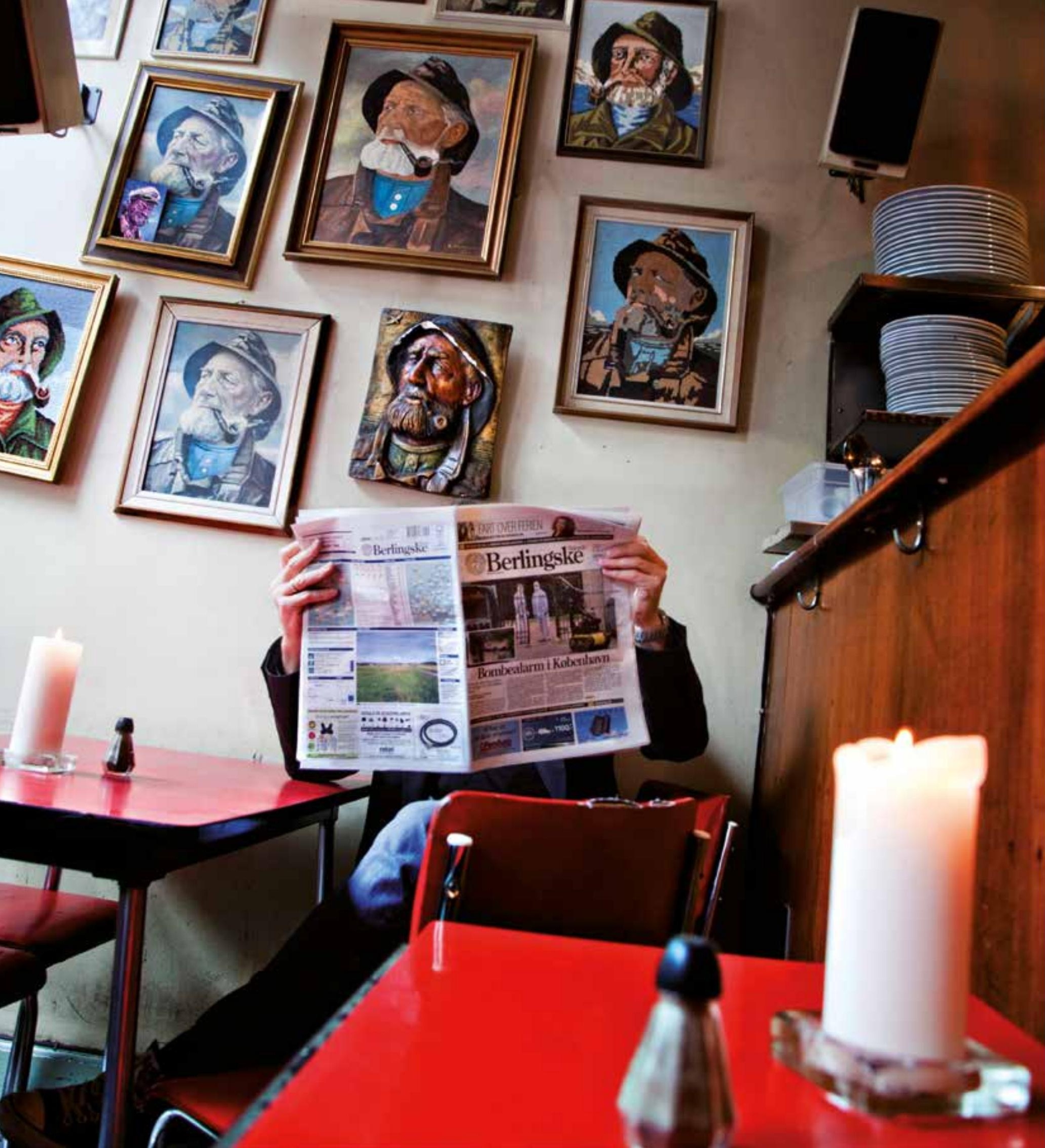




\section{Hinder på
utbildningsområdet \\ Hinder på
utbildningsområdet \\ ent}




\title{
Ingen rätt till studiestöd efter arbete utomlands
}

\author{
De flesta nordiska länder har ett bosättningskrav i sin studiestödslagstiftning. \\ För att ha rätt till studiestöd måste sökanden därför i regel ha bott två av \\ de senaste fem åren i sitt hemland. Det gör att personer som rört sig över \\ gränserna och jobbat i ett annat land kan ha svårigheter att få studiestöd
}

Ett gränshinder prioriterat av Sten Palmgren, Finland och Gunnar Westerholm, Åland.

Hindret kan lösas av Folkpensionsanstalten samt Undervisnings- och kulturministeriet (Finland), Styrelsen for Videregående Uddannelser och Uddannelses- og Forskningsministeriet (Danmark) och Kunnskapsdepartementet (Norge).

Prioriterat sedan 2014

\section{Bakgrund}

Huvudregeln i de nordiska länderna är att det är hemlandet som ska betala ut studiestöd. Således ska till exempel en finsk medborgare som väljer att studera i Sverige få sitt studiestöd från Finland. Den finska lagstiftningen kräver dock att personen ska ha bott två av de senaste fem åren i hemlandet, alltså Finland, för att få studiestöd.

Problemen uppstår då en person först flyttar från sitt hemland till ett annat land för att arbeta, och sedan flyttar vidare till ett tredje land för att studera. I sådana fall har personen vanligtvis inte tjänat in rätt till studiestöd i sitt studieland, eftersom det kräver att personen bor i studielandet $i$ två år. Personen har heller ingen rätt till studiestöd från sitt hemland om hon/han inte bott där under två av de senaste fem åren.
Konsekvensen blir att de unga människor som har utnyttjat den gemensamma nordiska arbetsmarknaden har sämre ekonomiska förutsättningar för att studera jämfört med de som stannat kvar i sitt hemland. De nationella regelverken är dessutom i strid med Helsingforsavtalet artikel 9 där det framgår att "ekonomiskt stöd från hemlandet bör kunna utgå, oavsett till vilket land studierna förläggas.”

\section{Vem påverkas}

Nordiska studerande som bott/ arbetat utomlands innan de inleder sina studier.

\section{Ekonomiska konsekvenser}

Gränshindret som beskrivs här förutsätter att en person först flyttar från sitt hemland till ett annat land för att arbeta, och sedan flyttar vidare till ett tredje land för att studera på högskolenivå. Antalet som gör denna tredje flytt för att studera är begränsat, enligt uppskattningarna rör det sig endast om ett tiotal personer i Danmark respektive Finland. Studiestödet för en dansk student är 65140 DKK/år och studiestödet för en finsk student är 4531 EUR/år. Genom att inte betala ut studiestöd åt de personer som drabbas av hindret sparar den finska staten cirka 50000 EUR/år, danska staten å sin sida sparar cirka 1121000 DKK/år. Närmare beräkningar finns nedan.

\section{Förslag till lösning}

Bosättningskravet i de nationella regelverken bör utgå. Alternativt kan perioder av sysselsättning i andra EU-länder och nordiska länder sammanläggas. 


\section{Gränshinderrådets arbete med frågan \\ Nuvarande status}

Hindret är på väg att lösas, då ländernas nya regler öppnar för andra bedömningskriterier än krav på bosättning eller vistelse och minskar därmed i hög grad problemet.

\section{Utbildningsdepartementet, SE:}

Sverige har nyligen ändrat tillämpningen av bosättningskravet för de personer som ska studera inom EU/EES eller Schweiz och som omfattas av EU-rätten på så sätt att den som ansöker om studiestöd istället ska vara samhällsintegrerad.

\section{Ole Stavad, DK:}

I Danmark har reglerna nu ändrats så att den studerande ska visa att han/hon har särskild anknytning till Danmark.
Stein Ludvigsen, NO:

I Norge ändras reglerna från och med 2015-2016, då villkor om en viss anknytning till Norge införs. De nya kraven gäller inte för den som bara ska gå delar av utbildningen i ett annat nordiskt land.

\section{Gunnar Westerholm, AX:}

Åland kommer att ändra sin lagstiftning 2015-2016 så att praxis inte kommer innehålla något boendekrav.

\section{Sten Palmgren, FI:}

Gränshinderrådet har följt processen i Finland under 2015. Det förslag till ändring av lagstiftningen som gällde hindret ingick i ett större sammanhang som inte godkändes under förra riksmötet. Efter 2015 års riksdagsval överlämnade den nya regeringen en ny proposition i saken.
Folkpensionsanstalten samt undervisnings- och kulturministeriet, FI: I proposition nr 40/2015 rd föreslår regeringen att bosättningskravet för rätten till studiestöd slopas. Förutsättningarna för att bevilja studiestöd för studier utomlands ändras så att stöd kan beviljas även när studeranden kan anses ha fast anknytning till Finland fastän han eller hon inte är bosatt där. I förslaget beaktas den ökade rörligheten och EU-domstolens avgöranden. Regeringens proposition har behandlats av riksdagens grundlagsutskott (GrUU $6 / 2015$ rd) och kulturutskottet har gett sitt betänkande i saken (KuUB 5/2015 rd). Avsikten är att lagändringen ska träda i kraft den 1 augusti 2016.

Läs mer i Gränshinderdatabasen, granshinder.norden.org, gränshinder nr: 14-036. 


\section{Beräkningar}

\section{Finland, befolkning 5451270}

Totalt antal finska medborgare som flyttat till ett nordiskt land och sedan flyttat vidare till ett tredje nordiskt land

Andel finländare i åldern 20-29, dvs. normal studieålder

Antal finska medborgare i åldern 20-29 år som flyttat till ett nordiskt land och sedan flyttat vidare till ett tredje nordiskt land

Andel finländare med lägre/högre högskoleutbildning

Antal finska medborgare i åldern 20-29 år som flyttat till ett nordiskt land och sedan flyttat vidare till ett tredje nordiskt land som förväntas ta en högskoleutbildning

Antal finländare som drabbas av gränshindret

\section{Danmark, befolkning 5639719}

Totalt antal danska medborgare som flyttat till ett nordiskt land och sedan flyttat vidare till ett tredje nordiskt land

Andel danskar i åldern 20-29, dvs. normal studieålder

Antal danska medborgare i åldern 20-29 år som flyttat till ett nordiskt land och sedan flyttat vidare till ett tredje nordiskt land

Andel danskar med lägre/högre högskoleutbildning

Antal danska medborgare i åldern 20-29 år som flyttat till ett nordiskt land och sedan flyttat vidare till ett tredje nordiskt land som förväntas ta en högskoleutbildning

Antal danskar som drabbas av gränshindret 


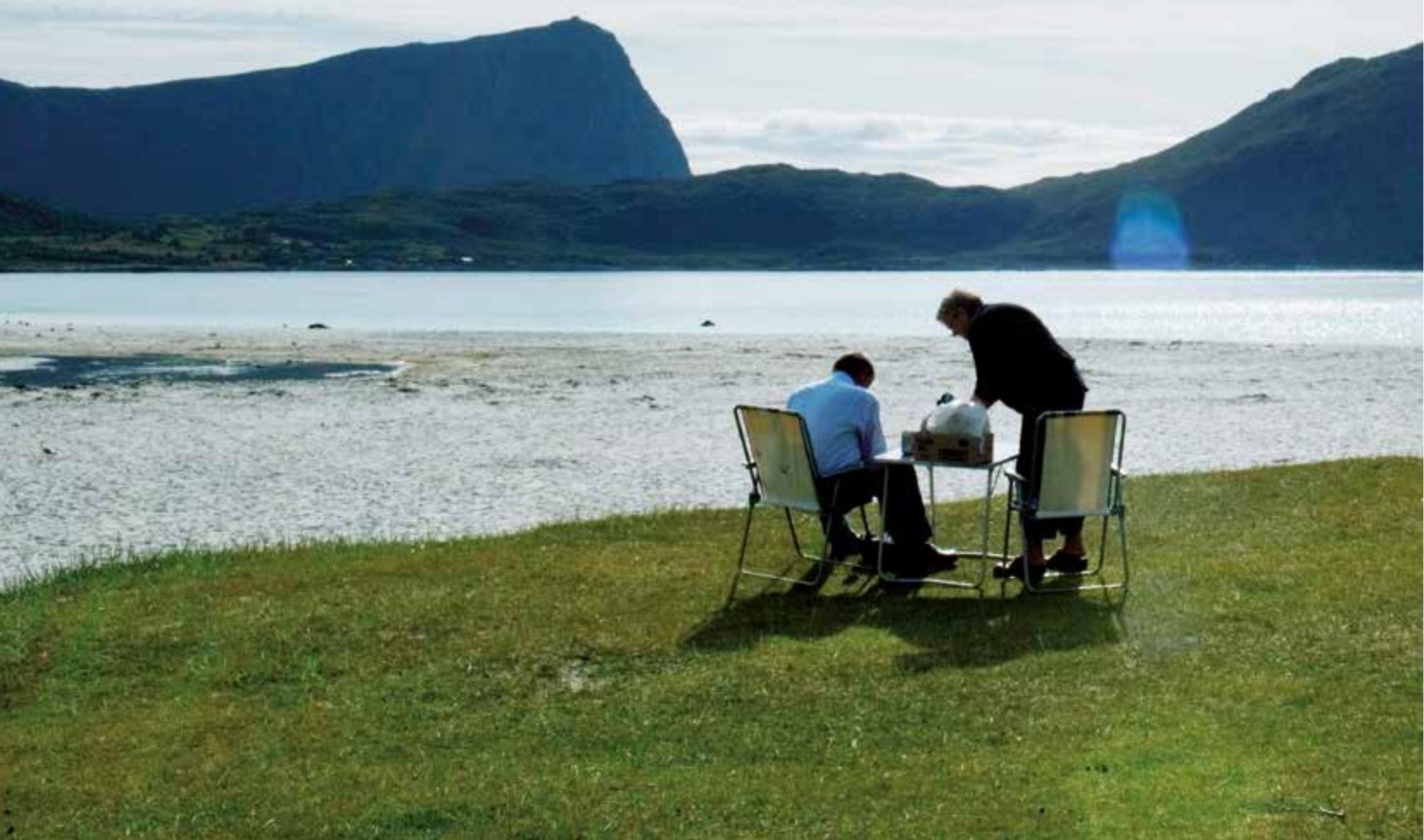




\section{EU:s mobilitetsprogram}

\section{Tillämpningen av en förordning inom det arbetsmarknadspolitiska regelverket försvårar för ungdomar som står långt från arbetsmarknaden att göra praktik och delta i utbildning i andra EU- och EES-länder.}

Ett prioriterat gränshinder av Annika Hahn Englund, Sverige och Siv Fridleifsdottir, Island.

Hindret kan lösas av de nordiska Arbetsmarknadsdepartementen.

Prioriterat sedan 2015

\section{Bakgrund}

Ett antal länder i Norden har svårt att använda EU:s mobilitetsprogram för icke-formellt och informellt lärande. EU-programmet Erasmus+ Ung och Aktiv, som erbjuder unga möjligheter till praktik (inklusive volontärarbete) och utbildning är ett sådant exempel.

Arbetsförmedlingen, Europeiska socialfondens råd (ESF-rådet) och Myndigheten för ungdoms- och civilsamhällesfrågor har lyft fram att det finns behov av en förändring av rådande regelverk.

Det är främst unga som står långt från arbetsmarknaden som påverkas negativt av regelverket och dess tillämpning. Ungdomars återinträde i utbildning eller arbete riskerar därmed att försvåras.
Både Island och Sverige har identifierat problemet (i Sverige redovisas det i regeringens proposition 2013/14:191 Med fokus på unga - en politik för goda levnadsvillkor, makt och inflytande).

\section{Vem påverkas}

De unga människor i de nordiska länderna som står längst från arbetsmarknaden.

\section{Gränshinderrådets arbete med frågan/kommentarer från berörda regeringar \\ Siv Fridleifsdottir, IS: \\ På Island innhentes information om hinderet og nå er saken i process og avgørelse mellom Grensehinderrådets representant og myndighetene.}

Arbetsmarknadsdepartementet och Utbildningsdepartementet, SE: Arbetsmarknadsdepartementet och Utbildningsdepartementet i Sverige har inlett samtal om hur frågan kan tas om hand.

Läs mer i Gränshinderdatabasen, granshinder.norden.org, gränshinder nr: $15-006$ 


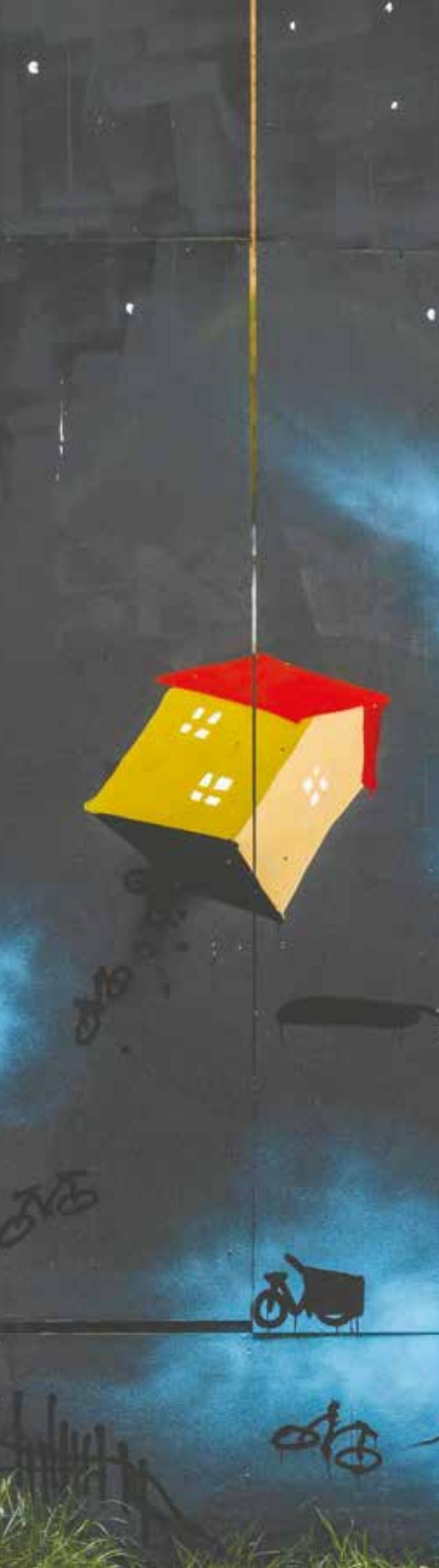




\section{Erkännande av yrkeskvalifikationer}

\section{Många yrken i Norden är reglerade antingen från statligt håll, exempelvis i lag eller genom branschspecifika föreskrifter. Eftersom kraven skiljer sig mellan de nordiska länderna uppstår det hinder för arbetstagarnas fria rörlighet.}

Ett prioriterat gränshinder av Dagfinn Høybråten, Nordiska ministerrådet och Marit Nybakk, Nordiska rådet.

Även prioriterat av MR-U och MR-NER.

Arbetet med hindret kräver koordinering mellan de nordiska arbetsmarknads- och utbildningsministerierna.

Prioriterat sedan 2014

\section{Bakgrund}

Nordiska ministerrådet har som en del av programmet Hållbar nordisk välfärd, låtit konsultföretaget DAMVAD göra analysen "Lovregulerede erhverv og velfærdsprofessioner". Det är en rapport som bland annat kartlägger alla statligt reglerade yrken i Norden. Resultaten visar att antalet reglerade yrken varierar stort mellan de nordiska länderna; Island med 171 statligt lagreglerade yrken har flest, Norge har 165 och Danmark 162. Sverige har 91 och Finland 74. Analysen visar också att de yrken som är statligt reglerade ger färre gränshinder än de som är branschspecifikt reglerade.

Arbetet med gränshindret är nära kopplat till implementeringen av EU:s nya yrkeskvalifikationsdirektiv. Det är dock svårt att hitta en slutlig lösning på gränshindret, eftersom problematiken rör flertalet branscher och många länder.
Gränshinderrådet har därför valt en mer långsiktig strategi och fokuserar sitt arbete på att underlätta en samnordisk implementering av direktivet. På sikt kommer en ökad koordinering av implementeringen av direktivet förhoppningsvis att bidra till ett minskat antal problem på grund av skillnader $\mathrm{i}$ kvalifikations- och utbildningskrav.

De tjänstemän som arbetar med implementeringen träffades i februari 2015 , där de nationella koordinatorerna för direktivet deltog. Nätverket samlades på nytt $\mathrm{i}$ juni och oktober 2015.

\section{Förslag till lösning}

Underlätta erfarenhetsutbyte under genomförandefasen av EU:s yrkeskvalifikationsdirektiv.

\section{Gränshinderrådets arbete med frågan/Kommentarer från berörda regeringar \\ MR-U:}

Regelverken gällande ömsesidigt erkännande av yrkesmässiga kvalifikationer, som reglerar auktoriserade yrken, är i vid utsträckning förankrade i EU-lagstiftningen. För närvarande pågår en modernisering av yrkeskvalifikationsdirektivet 2005/36/EG, vilket kommer att kunna främja mobiliteten av arbetskraft i EU/ EES. Alla nordiska länder deltar i arbetet.

Den ovan nämnda undersökningen om yrken och utbildningar inom hälso- och socialområdet har ett annat delprojekt, som har som syfte att bl.a. kartlägga likheter och skillnader i lagreglerade och auktoriserade yrken. På detta sätt identifieras potentiella gränshinder för arbetskraftsmobilitet i Norden. Enligt undersökningen ser man, att regelver- 
ken kring auktoriserade yrken i Norden är i det stora hela välfungerande och relevanta och bidrar till att skapa klarhet om medborgarnas rättigheter när de rör sig på den nordiska arbetsmarknaden. Det finns dock vissa utmaningar gällande branschspecifika krav, som kan i bland byggas upp decentraliserat t.ex. av branschernas egna organisationer och skapar för sin del gränshinder för mobiliteten.

Det vidare nordiska arbetet koordineras med det nationella arbetet $\mathrm{i}$ implementeringen av EU:s reviderade direktiv om erkännande av yrkeskvalifikationer. I arbetet ingår också EU:s insats kring European Professional Card. Ministerrådet har samlat experter och ansvariga koordinatorer för direktivets implementering i länderna som består av de ansvariga myndigheterna. Detta för att dela erfarenheter och kunskap om arbetet med implementeringen av direktivet och för att främja det nordiska perspektivet i det vidare arbetet på att säkra transparens och förenkling av direktivet.

På de senaste mötena har följande ärenden diskuteras:

- Implementering av alarmmekanismer vid fråntagande av auktoriseringar.

- Implementering av European Professional Card (EPC).

- Horisontell vis-a-vis vertikal lagstiftning.

- Användande av nationella kvalificeringsramar i det ömsesidiga erkännandet av yrkeskvalifikationer.

- Smart regulation.

- Etablering av ett nordiskt forum som ska diskutera och informera om nationell lagstiftning för auktoriserade yrken.
Läs mer i gränshinderdatabasen, granshinder.norden.org, gränshinder nr: 14-122. 


\title{
Vuxenutbildningsstöd till löntagare som blir studieledig
}

\author{
Gränsarbetare som bor i Finland, men som har arbetat en kort period \\ utomlands under de senaste åtta åren innan hon eller han lämnar in en \\ ansökan om vuxenutbildningsstöd i Finland, är inte berättigad till stödet.
}

Ett gränshinder prioriterat av Sten Palmgren, Finland.

Hindret kan lösas av Social- och hälsovårdsministeriet.

Prioriterat sedan 2014

\section{Bakgrund}

Det grundläggande kravet för att en person bosatt i Finland ska vara berättigad till finskt vuxenutbildningsstöd är att hon/han varit pensionsförsäkrad i en oavbruten period om åtta år i Finland. Det kravet är uppfyllt om personen har en arbetshistoria som sträcker sig minst åtta år bakåt, där det senaste arbetsförhållandet ska ha varat i minst ett år och omfatta minst 18 timmars arbete per vecka. I sådana fall har personen rätt till vuxenutbildningsstöd om hon eller han vill studera i minst två månader och inte får annat stöd för sina studier.

En finsk arbetstagare som bor i Finland, men som jobbat utomlands under de senaste åtta åren tappar dock sin rätt till finskt vuxenutbildningsstöd. Orsaken är att arbete utanför Finlands gränser gör att personen blir pensionsförsäkrad i sitt arbetsland. Det innebär att det blir ett avbrott i personens tid som pensionsförsäkrad i Finland, vilket innebär att personen mister rätten till vuxenutbildningsstöd. Således har en gränsarbetare inte samma ekonomiska förutsättningar för vidareutbildning som en arbetstagare som enbart jobbat $i$

Finland.

\section{Vem påverkas}

Detta hinder påverkar potentiellt samtliga medborgare som bor i Finland, men som arbetat utomlands under de senaste åtta åren.

\section{Ekonomiska konsekvenser}

En person som beviljas vuxenutbildningsstöd får i snitt 7369 EUR (2013). Omkring 1900 personer/år får avslag på deras ansökan om vuxenutbildningsstöd. Det finns dock inga siffror på hur många avslag som beror på att av kravet på en oavbruten pensionsförsäkringsperiod om åtta år i Finland inte är uppfyllt. Om antagandet är, att det är grunden till $10 \%$ av avslagen, innebär det att 190 personer inte ges vuxenut- bildningsstöd. Genom att inte betala ut vuxenutbildningsstöd åt dessa 1900 personer sparar finska staten således cirka 1,4 miljoner EUR/år. Närmare beräkningar finns nedan.

\section{Förslag till lösning}

Istället för de förutsättningar som nämns ovan kunde utgångspunkten vara att den som söker vuxenutbildningsstöd ska uppfylla de så kallade arbetsvillkoren för löntagare. Personen skulle i så fall beviljas stöd om hon eller han har förvärvsarbetat i 26 veckor under de 28 senaste månaderna (granskningsperiod), arbetat minst 18 timmar $i$ veckan och haft en på lön minst 1154 EUR/månad.

\section{Gränshinderrådets arbete med frågan/Kommentarer från berörda regeringar \\ Sten Palmgren, FI: \\ Frågan har behandlats tillsammans med Social- och hälsovårdsministeriet.}


Saken ingår i programmet för den regering som tillsattes 2015. Diskussioner pågår om vuxenutbildningsstödet ska ingå i regeringens sparåtgärder. Hur som helst kommer saken att föras till riksdagen och regeringen kommer att föreslå att arbete i EU/EES-länder och Schweiz ska beaktas. Reformen görs 2016 och innebär alltså att åttaårsregeln försvinner.
Läs mer i Gränshinderdatabasen, granshinder.norden.org, gränshinder nr: 14-158.

\section{Beräkningar}

Finska Utbildningsstyrelsen har levererat upplysningar om beviljade vuxenutbildningsunderstöd - både antal personer och utbetalda belopp, samt dessutom uppgifter om hur många personer som har fått sin ansökan avslagen.
Det saknas information om hur många ansökningar som har avslagits på grund av att den som ansökte inte hade varit pensionsförsäkrad i åtta år. Därför är $10 \%$ enbart ett exempel.

Antal personer som beviljats vuxenutbildningsstöd 2013

15362 personer

Totala utbetalningar av vuxenutbildningsstöd 2013

113200000 EUR

Beviljat belopp per person

7369 EUR

Antal personer som får avslag på sin ansökan om vuxenutbildningsstöd

1900 personer

Antagande: $10 \%$ av avslagen beror på att kravet om en obruten pensions-

försäkringsperiod inte är uppfyllt

Antal personer som drabbas av gränshindret

190 personer 


\title{
Godkännande av grönländska utbildningar
}

\author{
För den som tar en examen på Grönland och senare vill arbeta i ett \\ annat nordiskt land, finns det en risk att utbildningen inte är godkänd \\ och därför inte kan användas till något.
}

Ett prioriterat gränshinder av Christian Wennecke.

Departementet för utbildning, kultur, kyrka och jämställdhet.

Prioriterat sedan 2014

\section{Bakgrund}

För ett antal utbildningar krävs certifiering/legitimering för att få arbeta inom det yrke som utbildningen omfattar, så kallade reglerade yrken. Det gäller till exempel för vårdpersonal inom social och hälsa.

Det kan uppstå problem med att få anställning i ett annat nordiskt land, om det andra landet inte godkänner utbildningen. Det pågår redan ett arbete i nordisk regi kring detta hinder, där ambitionen är att få länderna att samarbeta kring implementeringen av det nya yrkeskvalifikationsdirektivet. Det har inspirerat till att även se på hindret ur ett grönländskt perspektiv.

För samhället blir det en vinst då utbildade personer arbetar i andra länder under en period för att få ny erfarenhet och nya kvalifikationer som de kan ta med sig tillbaka. Men hindret kan också redan vid valet av att utbilda sig på Grönland eller i ett annat land, bidra till att påverka personer att studera utomlands, om utbildningen i hemlandet inte ger samma möjligheter.

\section{Förslag till lösning}

Det finns en utredning av danska DAMVAD avseende yrkescertifiering/-legitimation i nordisk regi. Denna utredning följs av departementet för utbildning, kultur, kyrka och jämställdhet.

Det bör samtidigt inledas en intern utredning på Grönland, i syfte att bedöma om grönländska utbildningar godkänns i övriga nordiska länderna.

\section{Vem påverkas}

Departementet og de grønlandske huse er ikke bekendt med borgere som har oplevet problemet.

På Ilisimatusarfik (Grønlands Universitet) har man kendskab til to, som er blevet gymnasielærere med en af deres uddannelser.
Universitetet har gjort opmærksom på at grønlandske uddannelser ikke akkrediteres, og at det i princippet kan give studerende problemer, når de med en grønlandsk bachelor vil søge optagelse på et universitet i et andet land.

Det ikke muligt at anvende en grønlandsk politi-uddannelse i Danmark, til trods for at det er det danske politi, som opererer i Grønland.

Der kan være andre uddannelser, hvor det også gælder.

\section{Kommentarer från relevanta mi- nistrar/ministerier/departement Christian Wennecke, GL: \\ Grænsehindringsrådet rejser nye sager, inden for de enkelte uddannelser, når det bliver klart at der er et konkret problem.}

Grænsehindringsrådet følger arbejdet i Departementet med at få akkrediteret de grønlandske uddannelser internationalt. 
Departementet for Uddannelse, Kultur, Forskning og Kirke, GL:

Departementet for Uddannelse, Kultur, Forskning og Kirke er ikke bekendt med hindringer i forbindelse med anerkendelse af grønlandske uddannelser.

De grønlandske huse i Danmark, som også har kontakten med studerende uden for Danmark og Grønland, har heller ikke kendskab til tilfælde, hvor manglende anerkendelse af en grønlandsk uddannelse har været en hindring.

Ingen uddannelser i Grønland er akkrediteret. Dog er lovgivningen i Grønland, at det er op til hvert akademisk råd og branchebestyrelse at foreslå hvilken grad hver uddannelse skal have (jf. Inatsisartutlov nr. 10 af 19. maj 2010 om erhvervsuddannelser og kurser på erhvervsuddannelsesområdet).

Departementet for Uddannelse, Kultur, Forskning og Kirke er dog blevet bekendt med, at når studerende fra Ilisimatusarfik skulle fortsætte deres studier på f.eks. danske universiteter kan der opstå problematikker. Problematikkerne er f.eks., at ved en opnået bachelorgrad fra Ilisimatusarfik, kan studerende i nogle tilfælde ikke blive optaget på kandi- datstudiet uden at have gennemført fag på bachelorniveau på det pågældende universitet den studerende ønskede at starte på. Et yderligere problem i denne forbindelse er, at når studerende påbegynder disse kandidatforberedende fag, har studerende afsluttet deres studiestøtteberettigelse for deres bacheloruddannelse i Grønland. Da studerende overgår til dansk studiestøtteordning ved studieforløb i Danmark, opstår der derved et problem med hvilken studiestøtteordning studerende skal have ved de kandidatforberedende fag. I tilfælde af, at en grønlandsk studerende overgår til den danske studiestøtteordning vil den studerende ikke have nok klip til at fuldføre kandidatuddannelsen.

Universitetet på Færøerne oplever efter sigende samme problem som ovenstående.

En mulighed, der er værd at tage op til diskussion i Grænsehindringsrådet, er at tage udgangspunkt i Bologna-processen og sammenlægge akkrediteringen med det meritsystem baseret på ECTS og derved akkreditere de enkelte fag fremfor hele uddannelser. Dette vil betyde, at en studerende med en opnået bachelorgrad i Grønland kan gennemføre fag på bachelorniveau på danske universiteter på dansk studiestøtteordning på bachelorniveau. Dette kan derved fremme mobiliteten.

Ifølge Bologna-processen, som en betegnelse for et mellemstatsligt europæisk samarbejde om at skabe et fælles rum for videregående uddannelser i Europa, er formålet at udvikle et Europa, hvor studerende og forskere frit kan bevæge sig over grænserne. Hovedmålsætningerne er udvikling af letlæselige og sammenlignelige uddannelser og uddannelsesbeviser med en fælles gradstruktur (bachelor, kandidat, ph.d.) samt udvikling af et meritsystem baseret på ECTS for at fremme mobiliteten. De nordiske lande følger Bologna-processen, men der findes ingen fælles lov/ krav om akkreditering.

Eftersom der ikke er et problem om, at graden af en grønlandsk uddannelse ej anerkendes, findes det ikke hensigtsmæssigt at iværksætte en intern undersøgelse om anerkendelser i de nordiske lande.

Läs mer i Gränshinderdatabasen, granshinder.norden.org, gränshinder nr: 15-001. 


\title{
Öresundskommittén anser att det finns hinder för danska ungdomar att få praktikplats i Sverige
}

\author{
Öresundskommittén anser att det på grund av skillnader mellan \\ yrkesutbildningarna i Sverige och Danmark kan danska elever \\ (lærlinger) inte ansöka om praktikplats hos svenska företag.
}

Avvaktar och inväntar kommentarer från Öresundskommittén som utreder detta gränshinder.

Processen följs av Annika Hahn Englund, Sverige och Ole Stavad, Danmark.

Prioriterat sedan 2015

\begin{abstract}
Bakgrund
Enligt Öresundskommitténs beskrivning är den danska lärlingsutbildningen (erhvervsuddannelse) ett slags läroavtal där eleven varvar praktik med teori och får betalt för hela eller delar av utbildningstiden. Från svenskt håll anser man att den yrkesinriktade utbildningen $\mathrm{i}$ Sverige är mer teoretiskt inriktad än sin danska motsvarighet. En konsekvens av den skillnaden är att många svenskar söker till en dansk yrkesskola för att få en mer praktiskt orienterad utbildning.
\end{abstract}

Skillnaderna mellan utbildningarna medför dock att det är svårt för danska lärlingar att få praktikplats i Sverige. En bidragande orsak är att svenska praktikplatser i regel är oavlönade. För att en dansk lärling ska kunna tillgodoräkna praktikperioden krävs nämligen att praktiken utförs mot ersättning. Detta är särskilt problematiskt eftersom det finns färre praktikplatser i Danmark än i Sverige samtidigt som de danska lärlingarnas kompetenser efterfrågas i Sverige.

Elever på svenska yrkesutbildningar (den omvända situationen) kan i dag söka praktik i både Danmark och Sverige.

\section{Vem påverkas}

Elever som går lärlingsutbildning i Danmark och som önskar göra sin praktik i Sverige.

\section{Gränshinderrådets arbete med frågan/Kommentarer från berörda regeringar \\ Utbildningsdepartementet, SE:}

Det finns ett nordiskt avtal om gymnasieutbildning som möjliggör för ungdomar att genomgå en yrkesutbildning i ett annat nordiskt land. Svenska företag kan anställa danska ungdomar om de så önskar. Vidare finns det i Sverige en lag om gymnasial lärlingsanställning. Mot denna bakgrund anser Sverige att det behövs ytterligare utredning för att klargöra om det verkligen föreligger gränshinder av den karaktär som Öresundskommittén beskriver.

\section{Ole Stavad, DK:}

De danske og svenske regler for uddannelse af lærlinge er på afgørende punkter forskellige. Eksempelvis har danske virksomheder overenskomstmæssig pligt til at betale lærlinge løn i praktikperioden, mens lærlinge i Sverige oppebærer offentlig uddannelsesstøtte. Det har ikke været muligt at finde fælles regler, som muliggør at lærlinge under 


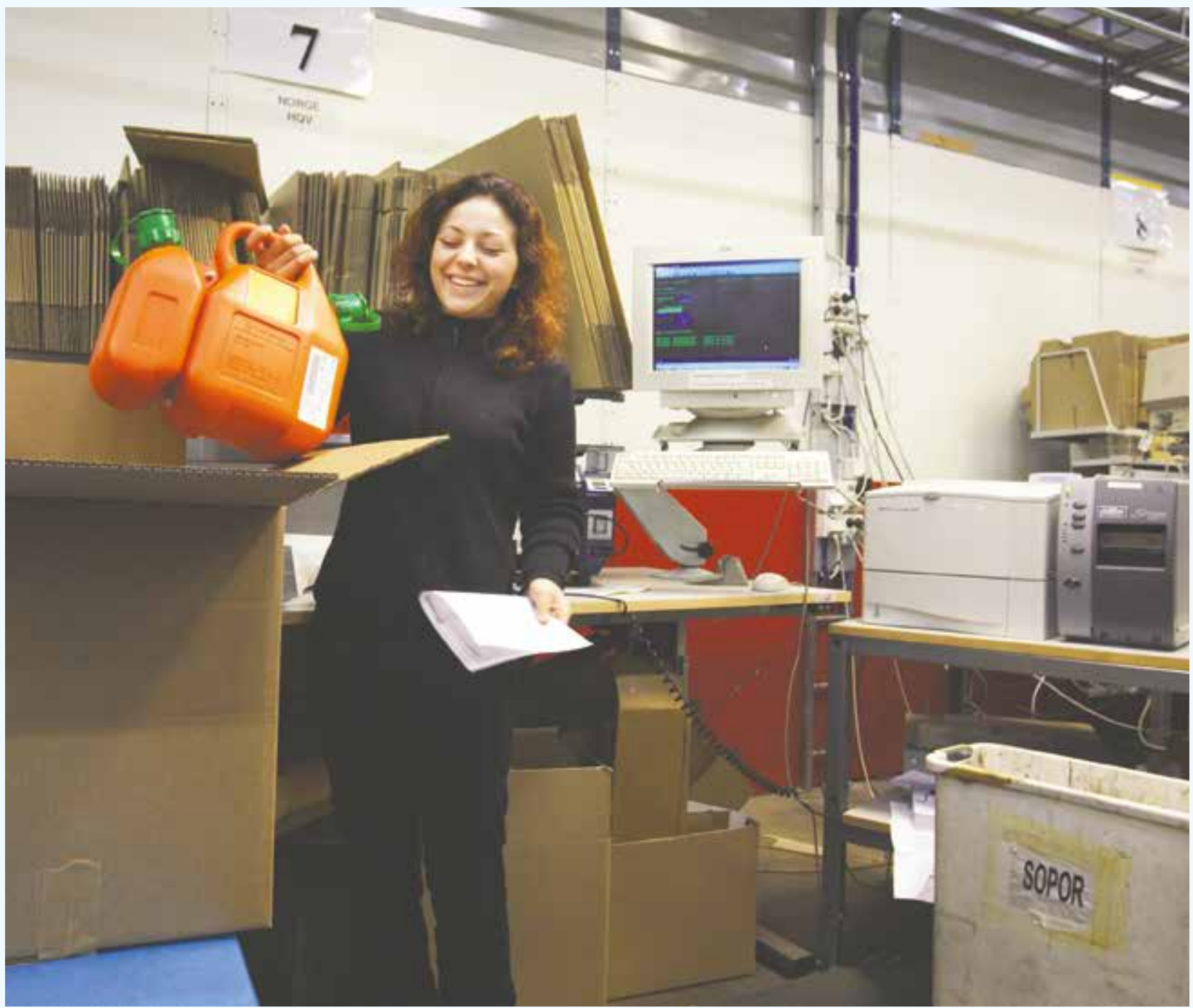

uddannelse kan søge praktikplads i Sverige. Det har været overvejet, om man kunne igangsætte et pilotprojekt i Øresundsområdet, men heller ikke på dette område er der sket fremskridt. På den baggrund er det svært at se, hvordan det er muligt at nå videre med sagen. Fortsætter man bestræbelserne på at finde en løsning, er det en afgørende forudsætning også at inddrage arbejdsmarkedets parter. Da spørgsmålet også er prioriteret af parterne i den særlige arbejdsgruppe under det danske formandskab, vil det samtidig være helt oplagt at overlade til parterne at fremkomme med forslag til løsning.
Läs mer i Gränshinderdatabasen, granshinder.norden.org, gränshinder $\mathrm{nr}$ : 14-170 


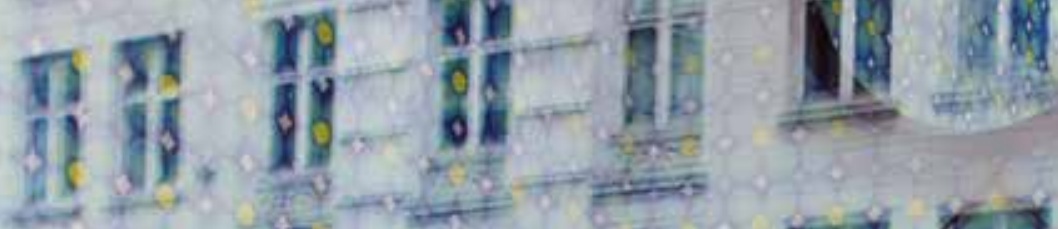

m

$5 x$

aropos

wis mons?

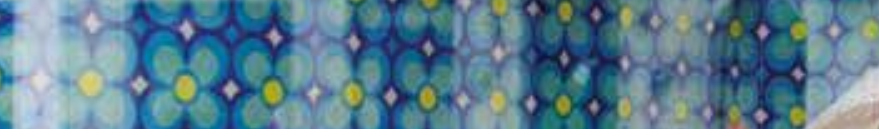

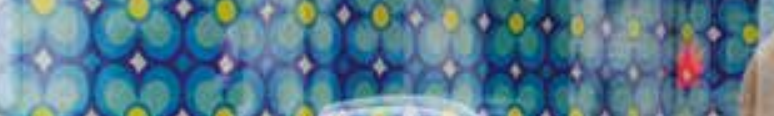

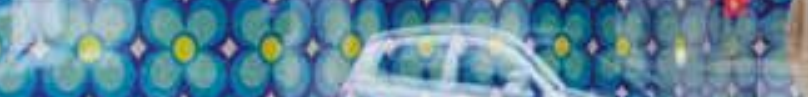

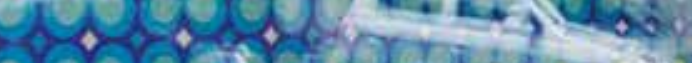
Kos 30300001 200030 (2003 03050 0300 303030 3030309 3063 30
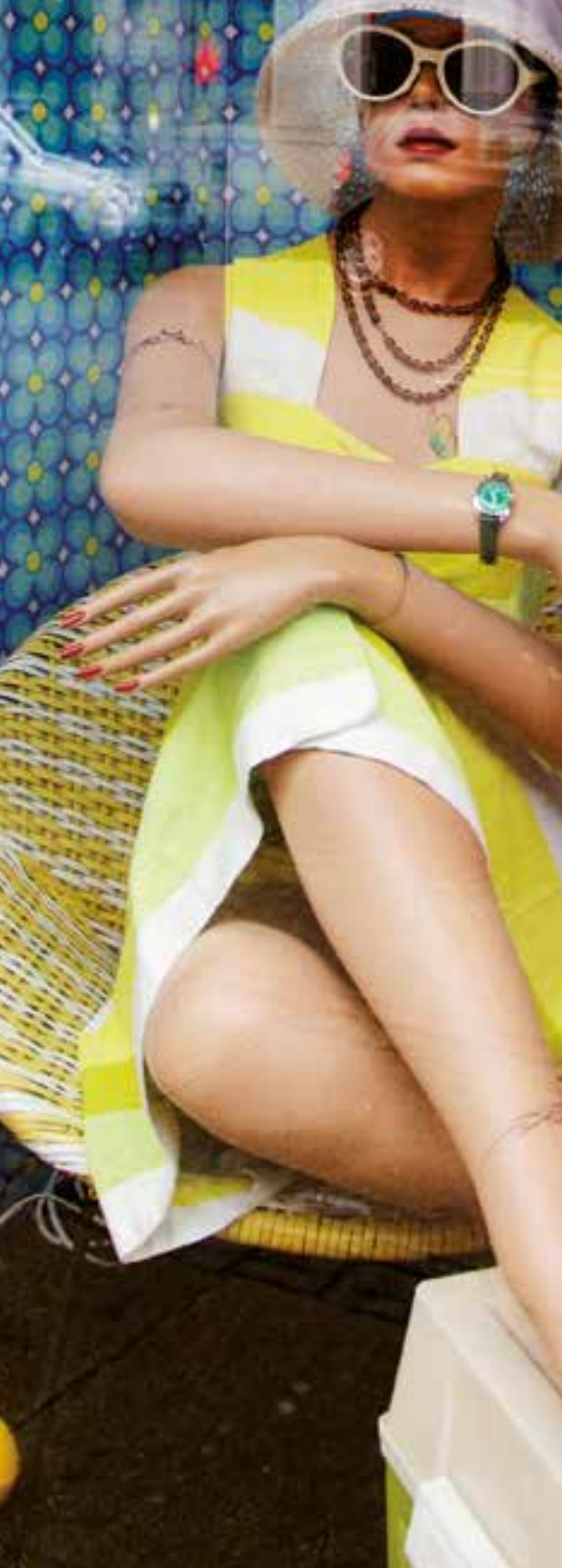

i

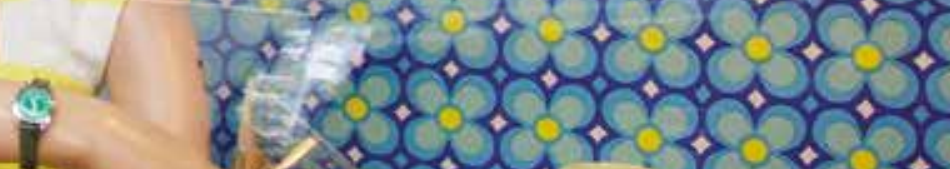

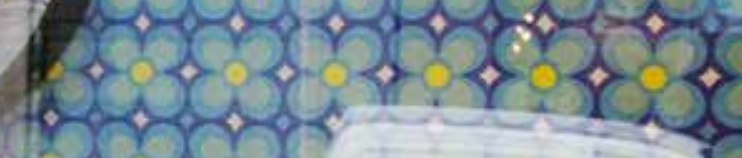
(1) mos monsirs? -

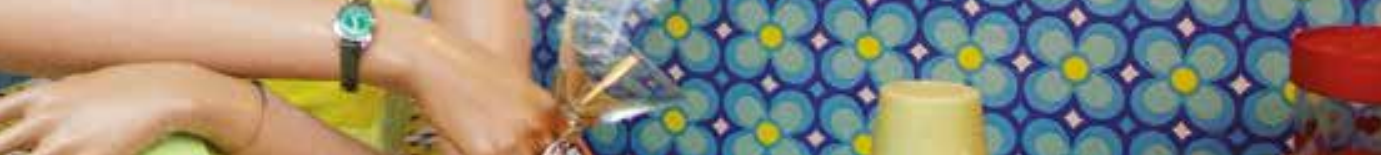




\section{Hinder på socialförsäkringsområdet}




\title{
Den norska faderskvoten
}

\author{
Män som arbetar i Norge, men som har en hustru/partner som inte \\ bor eller arbetar i Norge, har ingen självständig rätt till faderskvoten \\ (fedrekvoten) vid föräldraledighet med barn.
}

Ett prioriterat gränshinder av Svein Ludvigsen, Norge samt MR-S.

Hindret kan lösas av norska Barne-, likestillings- og inkluderingsdepartementet.

Prioriterat sedan 2014

\section{Bakgrund}

Rätten är härledd från moderns rätt. Faderns självständiga rätt till ersättning vid föräldraledighet förutsätter att modern är förhindrad att sköta barnet på grund av sjukdom, heltidsarbete eller heltidsstudier.

\section{Förslag till lösning}

Rapporten "Gränshinder i Norden på social- och arbetsmarknadsområdet" (Nord 2012:002) föreslår att gränshindret skulle kunna lösas med tolkning av artikel 5.a i EU-förordning 883/2004. Denna bestämmelse förutsätter att den behöriga medlemsstaten beaktar liknande förmåner enligt en annan medlemsstats lagstiftning eller inkomster i en annan medlemsstatlagstiftning som om dessa hade erhållits i enligt den egna medlemsstatens lagstiftning eller i den egna medlemsstaten.
På så sätt kunde män som arbetar i Norge härleda sin rätt till faderskvoten från sin hustru/partner oberoende av var hon arbetat. Moderns rätt till föräldrapenning i ett annat nordiskt land borde nämligen ha likvärdig betydelse som moderns rätt till föräldrapenning $i$ Norge enligt norsk lagstiftning.

\section{Vem påverkas}

Detta hinder påverkar par där fadern arbetar i Norge medan modern arbetar i ett annat nordiskt land före barnets födsel.

\section{Ekonomiska konsekvenser då detta hinder löses \\ Man estimerar att cirka 850 av gränspendlarna till Norge årligen blir fäder. Dessutom tillkommer övriga EU/ EES-länder}

\section{Gränshinderrådets arbete med frågan/kommentarer från berörda regeringar \\ Svein Ludvigsen, NO: \\ Norske barne- likestillings- og inklude- ringsdepartementet anser at saken ikke kan løses av politiske årsaker. Grense- hinderrådet avslutter derfor arbeidet med problemet.}

Läs mer i Gränshinderdatabasen, granshinder.norden.org, gränshinder nr: 14-126. 


\section{Beräkningar}

Man uppskattar att 850 av de manliga gränspendlarna till Norge årligen blir fäder. Maximalt skulle Norge därmed få en tilläggskostnad på 83,6 miljoner NOK genom att lösa detta gränshinder.

Huvudparten av de nyblivna fäderna är mellan 25 och 39 år. Omkring 9000 män i åldern 25-39 år pendlar till Norge från Danmark, Finland och Sverige. Det senaste kontrollerade antalet från Danmark och Sverige är från år 2009, det senaste antalet från Finland från år 2013. Talet för antalet finska gränspendlare är baserat på upplysningar från norska Skatteetaten och skiljer sig därför metodmässigt från beräkningen av gränspendlare till Sverige från Norge och Danmark. Statistiken gällande dessa sistnämnda pendlare baseras på upplysningar från nationell registerbaserad arbetsmarknadstatistik som publicerats i StatNord.

Utgående från antagandet att 80 \% av alla nyfödda har en far som är mellan 25-39 år, kan man beräkna att omkring 850 manliga pendlare till Norge årligen förlorar rätten till faderskapsersättning p.g.a. att de bor i ett annat nordiskt land.

Det maximala årliga beloppet som kan utbetalas som föräldraersättning är 530220 NOK. Eftersom faderns andel av föräldraledigheten är 10 veckor, kommer den maximala utgiften för den enskilde nyblivne fadern att vara 101965 NOK. Den totala utgiften för samtliga gränspendlare från Danmark, Sverige och Finland uppgår till 86,3 miljoner NOK. 


\title{
Studerandes socialförsäkring i ett annat nordiskt land
}

\author{
När det gäller rätten för studerande från nordiska länder att bli \\ socialförsäkrade i ett annat nordiskt land så finns det oklarheter \\ gällande vilket lands lagstiftning som är tillämplig.
}

Ett prioriterat gränshinder av Ole Stavad, Danmark samt MR-S.

Hindret finns även i avtalet mellan det danska Folketinget och regeringen om borttagande av nordiska gränshinder.

Prioriterat sedan 2014

\section{Bakgrund}

Förordning 883/2004 om koordinering av samordning av de sociala trygghetssystemen trädde i kraft den 1 maj 2010 för EU-länderna. I Norge och Island gäller samma samordningsregler mellan de nordiska länderna. Enligt förordning 883/2004 tillämpas bosättningslandets lagstiftning på icke-förvärvsaktiva personer, därmed även studerande, som ska omfattas av det landets lagstiftning där de är bosatta. Med bosättning menas enligt förordningen stadigvarande bosättning. Bosättning avgörs primärt enligt nationell lagstiftning.

\section{Tillämpningsförordning 987/2009} anger vissa kriterier för fastställande av bosättningsort om flera medlemsstaters institutioner har skilda uppfattningar om var en person är bosatt. Folkbokföringen är inte avgörande för fastställande av bosättningsland. Det ska bedömas var personen har sina hu- vudsakliga intressen. Eftersom många sociala tjänster i de nordiska länderna beror på bosättning är denna bedömning av stor betydelse för icke-förvärvsaktiva personer och studenter som flyttar mellan de nordiska länderna.

De nordiska länderna har inte heller likadana nationella regler om studenters socialförsäkring eller om hur länge de kan fortsätta att vara försäkrade i landet de kommer från. Även om samma samordningsregler gäller mellan alla de nordiska länderna så görs bedömningen av vem som anses vara bosatt i landet i varje enskilt fall. Det gör systemet mer komplicerat än det är i dag och det kommer att ta längre tid att få ett beslut om bosättning än att göra en ändring av folkbokföringen. Det kan också förekomma att vissa studenter anses som bosatta i inflyttningslandet, medan andra inte anses vara det. Socialförsäkringsskyddet för dem som inte anses bosatta i studielandet beror då på de nationella reglerna i landet som studenten kommer från.

Problemet kan då uppkomma att det land som studenten kommer från anser att han eller hon inte längre är försäkrad i det landet, samtidigt som landet som studenten flyttar till anser att hon eller han inte är bosatt eller försäkrad där.

\section{Förslag till lösning}

Länderna försöker hitta en gemensam uppsättning kriterier för när studerande omfattas av ett lands lagar, för att säkerställa att inga studerande som flyttar mellan de nordiska länderna riskerar osäkerhet om vilket lands lagstiftning som ska tillämpas.

\section{Vem påverkas}

Problemet påverkar troligen ett mindre antal studerande som rör sig över de nordiska gränserna. 


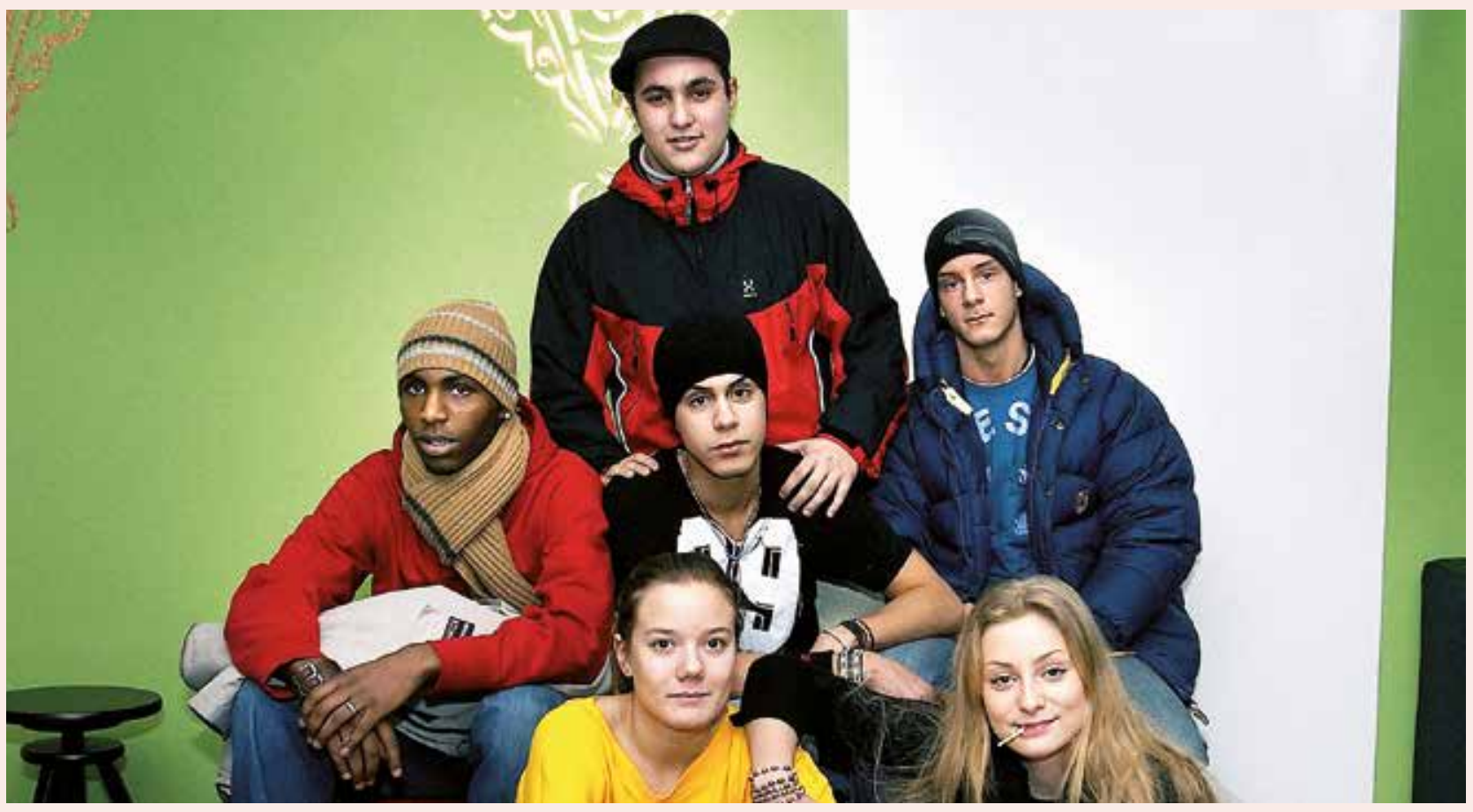

\section{Gränshinderrådets arbete med frågan/Kommentarer från berörda regeringar}

\section{Ole Stavad, DK:}

Hindret anses löst genom förordning $883 / 2004$ och genom ny nordisk konvention om social trygghet.

\section{Brev fra Socialministeriet, DK af}

\subsubsection{5:}

Problemstillingen er blevet rejst i Den Nordiske Socialforsikringsgruppe. Den Administrative Kommission for social sikring (EU) har udarbejdet en supplerende guide om lovvalg, som også indeholder kriterier for fastlæggelse af lovvalg for studerende. Den nordiske Socialforsikringsgruppe finder den supplerende guide dækkende til tydeliggørelse af de gældende landes lovgivning.
Mødereferat fra møde i Nordisk

\section{Socialforsikringsgruppe}

Den 24. august 2015, kl. 10-16

Social- og Indenrigsministeriet.

Opfølgning på sidste møde i socialforsikringsgruppen, afholdt den 12. september 2014 i Reykjavik

\section{Studerendes ret til social sikring under ophold $i$ et andet nordisk land}

På sidste møde i Nordisk Socialforsikringsgruppe lagdes op til, at problemstillingen skulle kortlægges på møde i forbindelsesorgansmødet med henblik på en drøftelse på dette møde i Socialforsikringsgruppen.
Emnet blev imidlertid ikke taget op til diskussion på forbindelsesorgansmødet. Nordisk Ministerråds Sekretariat mente, at problemet som udgangspunkt var begrænset til studiestød. Det er Nordisk Socialforsikringsgruppes vurdering, at EU-reglerne er tilstrækkelige. Man aftalte, at når der opstår konkrete vanskeligheder vil de nordiske lande i tæt samarbejde udrede den konkrete problemstilling.

Läs mer om i gränshinderdatabasen, granshinder.norden,org, gränshinder nr: 14-100. 


\title{
Sjukersättning patientresa mellan Norge och Finland/Sverige
}

\author{
En gränspendlare med bosättning i Finland eller Sverige med arbete i Norge är \\ socialförsäkrad och skattepliktig i Norge. Han eller hon får inte ersättning för \\ sina patientresor/behandlingsresor från hemmet i Finland/Sverige till sjukhuset \\ Norge till skillnad från sina arbetskollegor med bosättning och arbete Norge.
}

Ett prioriterat gränshinder av Svein Ludvigsen, Norge och Sten Palmgren, Finland.

Hindret kan lösas av norska Helse- og omsorgsdeparetmentet.

Prioriterat sedan 2014

\section{Bakgrund}

Huvudregeln är att gränsgångare ska täckas av sjukförsäkringen i sitt arbetsland. Om en finsk medborgare som är bosatt i Finland arbetar i Norge, omfattas hon eller han av det norska sjukförsäkringssystemet och ska därmed vända sig till norska hälsovårdscentraler/ sjukhus. Problemen uppstår då sådana gränsgångare hänvisas vidare till vidare utredning/behandling vid en annan hälsovårdscentral/sjukhus i Norge. Då betalar inte norska Pasientreiser (en myndighet under Helseøkonomiforvaltningen) ut ersättning för de resekostnader som gränsgångaren ådragit sig $\mathrm{i}$ samband med behandlingen.

Orsaken är att Pasientreiser kräver att alla behandlingsresor ska påbörjas och avslutas vid arbetsplatsen. För en person som är $100 \%$ sjukskriven kan det dock vara mycket svårt eller omöjligt att ta sig till arbetsplatsen från sitt hem på den finska sidan. Det innebär att personen själv måste betala kostnaderna för bil- och flygresor till behandlingsorten. För gränsgångare som bor och arbetar $i$ norra Finland/Norge kan det då bli fråga om stora summor. Personen kan också ha svårt att ta sig till behandling/rehabilitering i sitt bosättningsland (Finland) eftersom Pasientreiser/Helseøkonomiforvaltningen inte betalar resor inom Finland.

Motsvarande gäller för en gränspendlare som är bosatt i Sverige och arbetar i Norge.

\begin{abstract}
Vem påverkas
Detta hinder påverkar samtliga medborgare som arbetar i Norge och bor i Finland eller Sverige, cirka 32300 pendlare.
\end{abstract}

\section{Ekonomiska konsekvenser}

Den totala resekostnaden är beräknad till 462 EUR för en finsk pendlare som är bosatt i Utsjoki, arbetar i Kirkenes och har behov av specialistvård i Oslo. Den motsvarande siffran för en person som pendlar från Stockholm till Oslo är 153 EUR. Uppskattningsvis berörs cirka 210 gränspendlare från Finland och Sverige av hindret. Norska staten sparar i sin tur cirka 77000 EUR på att inte lösa hindret. Närmare beräkningar finns nedan. 


\section{Förslag till lösning}

Gränsgångare/nordiska arbetstagare får ersättning för reseutgifter i sitt hemland i förbindelse med läkarbesök och behandling enligt samma regler som norska och utländska arbetstagare bosatta i Norge.
Gränshinderrådets arbete med frågan/kommentarer från berörda regeringar

Svein Ludvigsen, NO:

Dette grensehinderet lar seg ikke løse ensidig fra norsk side. Skal det løses må det oppnås i samarbeid mellom de berørte lendene.
Läs mer i gränshinderdatabasen, granshinder.norden.org, gränshinder nr: 14-16.

\section{Beräkningar}

Antal pendlare från Finland till Norge (2013)

4124 personer

Kostnad för en finsk pendlare som bor i Utsjoki och i Oslo behöver specialistvård

- Transport från Ustjoki till Kirkenes flygfält

43 EUR

- Parkering vid Kirkenes flygfält

8 EUR

- Flyg tur/retur till Oslo

270 EUR

- Hotell i Oslo

100 EUR

- Transport tur/retur Oslo-Gardermoen

41 EUR 
Kostnad för en finsk pendlare som bor i Stockholm och i Oslo behöver specialistvård

- Transport tur/retur från Arlanda flygfält till Stockholm

\begin{tabular}{|c|c|c|c|}
\hline \multirow[b]{2}{*}{ Antal gränspendlare till Norge } & \multicolumn{2}{|c|}{ Finland } & \multirow{2}{*}{$\begin{array}{l}\text { Sverige } \\
28141 \text { personer }\end{array}$} \\
\hline & 4124 & Personer & \\
\hline \multicolumn{4}{|l|}{ Andel av totala arbetsstyrkan som varit sjukanmäld mer än } \\
\hline 28 dagar i sträck & 1,70 & $\%$ & $2,80 \%$ \\
\hline \multicolumn{4}{|l|}{ Antal gränspendlare som varit sjukanmälda mer än } \\
\hline 28 dagar i sträck & 71 & personer & 786 personer \\
\hline \multicolumn{4}{|l|}{ Antagande: en fjärdedel av de som varit sjukanmälda i mer } \\
\hline än 28 dagar i sträck har behov av specialistvård & 18 & personer & 196 personer \\
\hline \multicolumn{4}{|l|}{$\begin{array}{l}\text { Antagande: dessa personer har behov av specialistvård två } \\
\text { gånger under sjukdomsperioden }\end{array}$} \\
\hline Total resekostnad för en finsk gränspendlare (462 EUR x 2) & & & 924 EUR \\
\hline Total resekostnad för en svensk gränspendlare (153 EUR x 2) & & & 306 EUR \\
\hline Besparing för den norska staten för finska respektive svenska pendlare & 16632 & EUR & 59976 EUR \\
\hline Total besparing för den norska staten & & & 76608 EUR \\
\hline
\end{tabular}

Källor: Antal pendlare, Nordisk Pendlingskarta 2012 (från SE till NO) och norska Skatteetaten 2014 (från Fl till NO). Hotell i Oslo, pris för trestjärnigt hotell i Oslo på Booking.com. Flygresor, SAS och Norwegian, priser för december 2014. Parkering Kirkenes Lufthavn, avinor.no. Bränslekostnader: Det antas att bilen kör 15 km/l och att bensinen kostar 1,449 EUR per liter. Valutakurs: Norges Bank, Riksbanken samt Nationalbanken. 


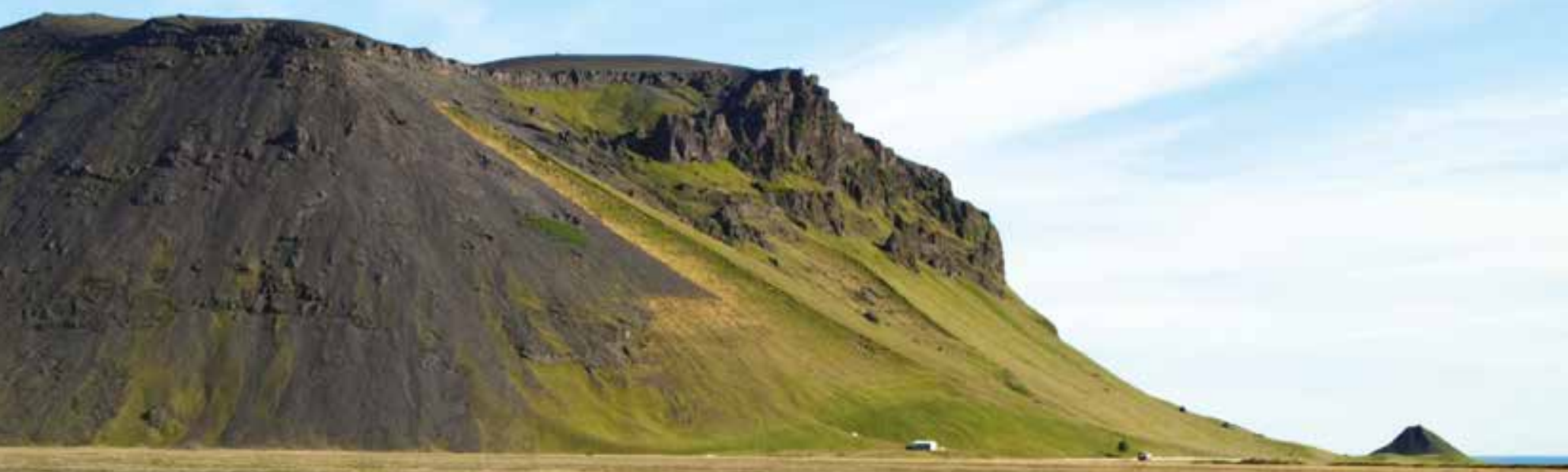

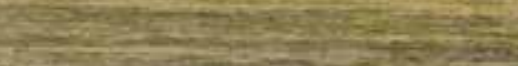

sestintanas

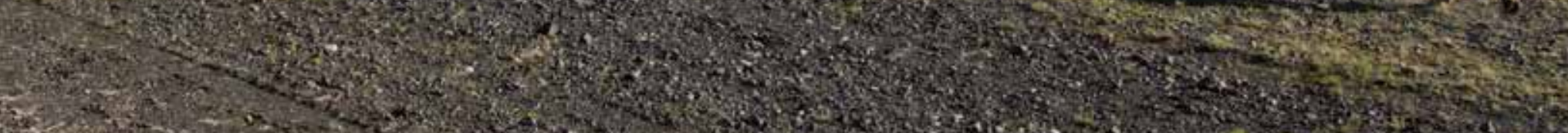

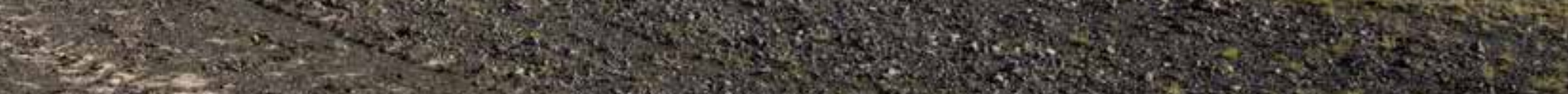

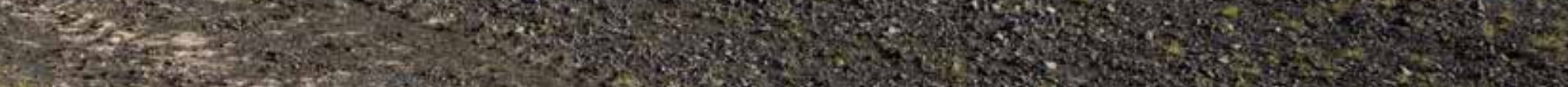
Q

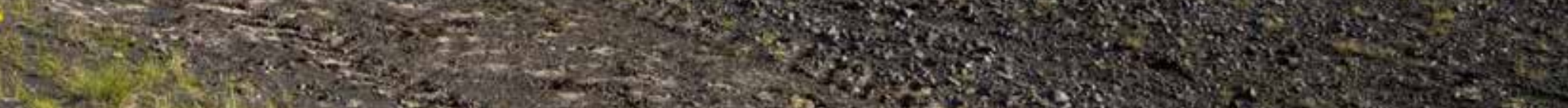

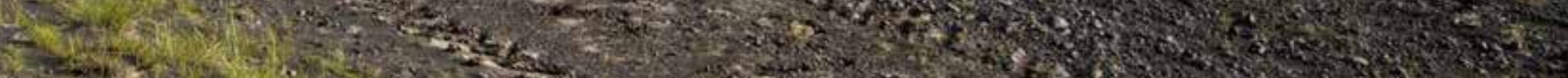

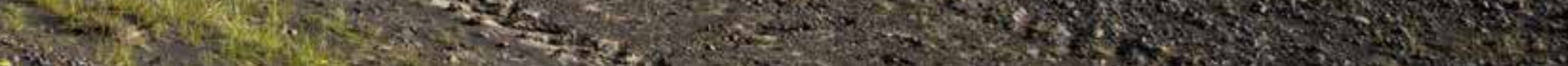




\title{
Krav på att omfattas av olika länders arbetslöshetsförsäkring utan avbrott för att inte riskera lägre arbetslöshetsersättning
}

\author{
Arbetstagare som får glapp i medlemsperioden i arbetslöshetskassan riskerar att \\ inte få rätt till den inkomstrelaterade ersättningen utan enbart den lägre grun- \\ dersättningen. Glapp kan bland annat uppstå när man börjar arbeta i ett annat \\ land än Sverige eller när en gränsarbetare återvänder till Sverige och söker ersät- \\ tning. Detta kan även uppstå för personer som enbart bor och arbetar i Sverige.
}

Ett prioriterat gränshinder av Annika Hahn Englund, Sverige. Även prioriterat av MR-A.

Hindret kan lösas av Arbetsmarknadsdepartementet i Sverige.

Prioriterat sedan 2015

\begin{abstract}
Bakgrund
Sverige har en arbetslöshetsförsäkring som består av två delar. Den allmänna delen, grundförsäkringen, omfattar alla arbetstagare och egenföretagare. Den frivilliga delen, inkomstbortfallsförsäkringen, omfattar den som har varit medlem i en arbetslöshetskassa under minst tolv månader. För att få rätt till den inkomstrelaterade arbetslöshetsersättningen krävs enligt svensk praxis bland annat tolv månaders sammanhängande medlemskap i en svensk arbetslöshetskassa eller motsvarande försäkrad tid från arbete i ett annat nordiskt land.
\end{abstract}

För Sveriges del rör gränshindret personer som omfattas av inkomstbortfallsförsäkringen och som påbörjar arbete $\mathrm{i}$ ett annat land utan att i samband med detta bli arbetslöshetsförsäkrade där. För att bli arbetslöshetsförsäkrad i Danmark, som till skillnad från Sverige har en uteslutande frivillig arbetslöshetsförsäkring, måste en person som börjar arbeta i Danmark ansöka om inträde i en dansk arbetslöshetskassa. Om personen inte direkt blev medlem i en dansk arbetslöshetskassa efter att han eller hon lämnade den svenska arbetslöshetskassan riskerar personen vid efterföljande prövning i Sverige att endast beviljas ersättning från grundförsäkringen på grund av bruten försäkringsperiod.

Även för de som inte blir medlemmar direkt i en svensk arbetslöshetskassa efter arbete i ett annat land kan drabbas av glapp i medlemsperioden. I de fall den så kallade femårsregeln $\mathrm{i}$ den nordiska konventionen om social trygghet är tillämplig kan en person beviljas återinträde i ett nordiskt lands arbetslöshetsförsäkring under förutsättning att ansökan om medlemskap görs inom åtta veckor från det att personen 


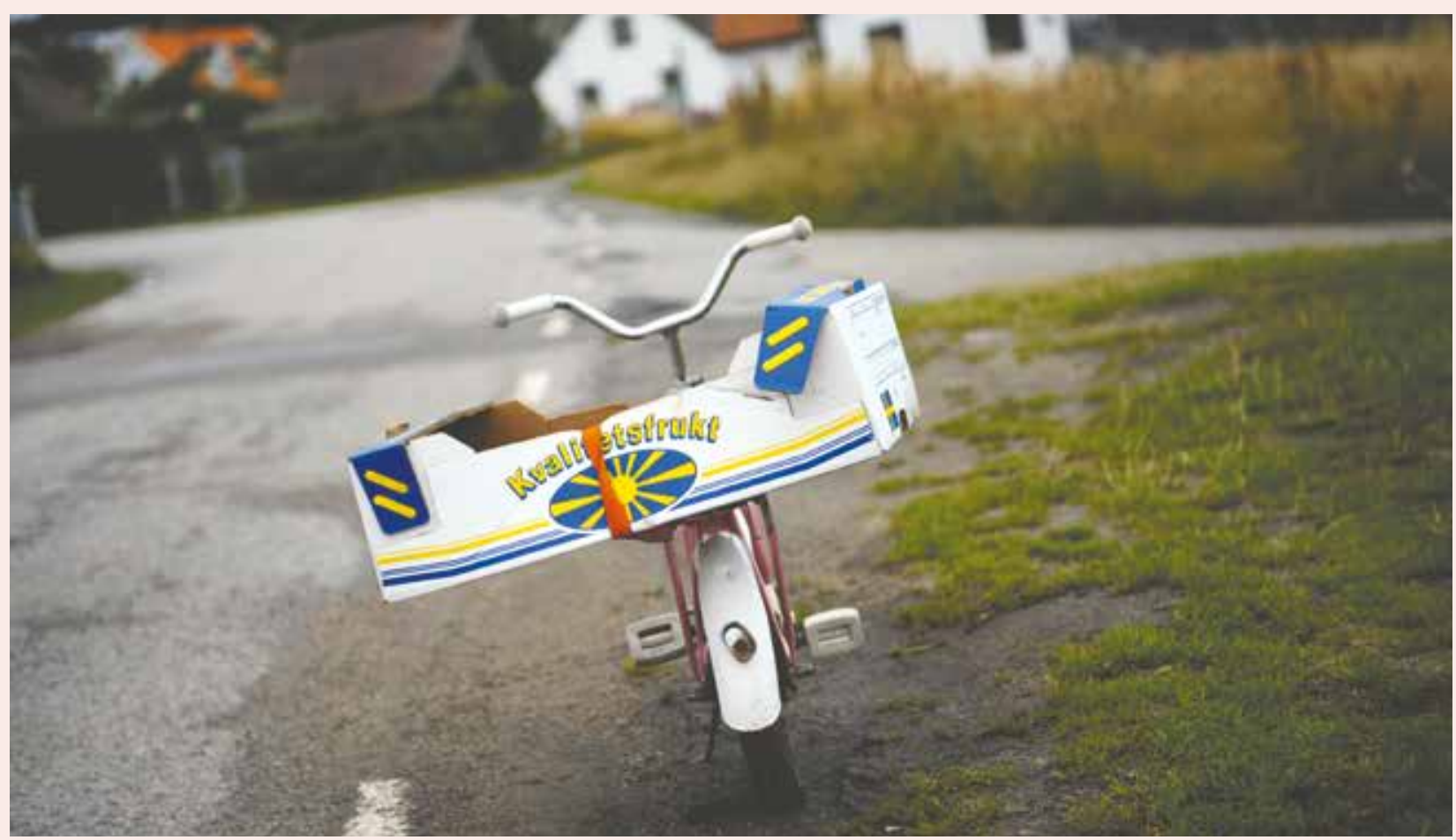

lämnade ett annat nordiskt lands arbetslöshetsförsäkring. Risken för glapp vid återinträde i den svenska arbetslöshetsförsäkringen minskar därmed i de ärenden där den nordiska konventionen är tillämplig.

Gränshindret motsvaras av nr B12 i rapporten "Gränshinder i Norden på social- och arbetsmarknadsområdet" (Nord 2012:002).

\section{Vem påverkas}

Personer som inte upprätthåller en sammanhängande försäkringstid (medlemsperiod) när de börjar arbeta i annat land eller återvänder till Sverige.

\section{Juridisk orsak}

Svensk praxis kräver bland annat tolv månaders sammanhängande medlemskap i en svensk arbetslöshetskassa eller motsvarande försäkrad tid från arbete i ett annat nordiskt land.

\section{Förslag till lösning}

En nordisk expertgrupp har i rapport Nord 2012:002 slagit fast att det behövs ett förtydligande i lagstiftningen om det krävs tolv månaders sammanhängande medlemskap i en arbetslöshetskassa för att få rätt till ersättning från inkomstbortfallsförsäkringen i Sverige. Ett eventuellt klargörande skulle kunna medföra att en period ska betraktas som obruten, även om en viss del av den de facto är oförsäkrad. Den danska arbetslöshetsförsäkringens så kallade åttaveckorsregel kan här vara till vägledning.

\section{Gränshinderrådets arbete med frågan/kommentarer från berörda regeringar}

Arbetsmarknadsdepartementet, SE: Arbetsmarknadsdepartementet i Sverige håller på att följa upp resultatet från den parlamentariska socialförsäkringsutredningens slutbetänkande. 


\title{
Finska fyramånadersregeln
}

\author{
Finland införde inför utvidgningen av EU 2004 regler om bosättnings- \\ baserade förmåner som innebär att personer som inte är bosatta i \\ Finland och vars arbetsförhållande inte är minst fyra månader långt, \\ inte heller är försäkrade för vissa socialförsäkringsförmåner som de \\ annars hade varit försäkrade för genom sin bosättning Finland.
}

Ett prioriterat gränshinder av Sten Palmgren, Finland. Även prioriterat av MR-S.

Hindret kan lösas av finska Social- och hälsovårdsministeriet.

Prioriterat sedan 2014

\section{Bakgrund}

När en person flyttar till Finland avgör Folkpensionsanstalten (FPA) om han eller hon ska omfattas av den finska bosättningsbaserade sociala tryggheten som FPA har hand om. Tryggheten omfattar följande förmåner: folkpension, barnbidrag, moderskapsunderstöd, bostadsbidrag, bostadsbidrag för pensionstagare, handikappförmåner, frontmannapension, garantipension och underhållsstöd. Även rätt till förmåner enligt sjukförsäkringslagen och lagen om Folkpensionsanstaltens rehabiliteringsförmåner och rehabiliteringspenningförmåner grundar sig på bosättning.

Om en person som kommer till Finland inte uppfyller villkoren för stadigvarande bosättning i Finland grundar sig rätten till FPA:s förmåner istället på arbete. Personer som omfattas av förordningarna 883/2004 och 1408/71 kan bli försäkrade och få rätt till FPA:s förmåner på basis av arbete om de under fyra månader arbetar minst 18 timmar i veckan och har en lön som motsvarar minst den lön som ska betalas enligt branschens kollektivavtal. Om det inte finns något kollektivavtal inom den aktuella branschen, ska lönen för arbetet vara minst 1154 EUR i månaden (2014) vid heltidsarbete. Detta krav brukar kallas fyramånadersregeln.

Personen är visserligen försäkrad för arbetspension, arbetsskada och olycksfallsförsäkring och har rätt till offentlig hälsovård i Finland, men har inte rätt till exempelvis barnbidrag eller sjukförsäkring (sjukdagpenning, föräldrapenning). Fyramånadersregeln drabbar i hög grad nordiska säsongsarbetare inom turistnäringen i norra Finland.

\section{Vem påverkas}

Enligt SOLMU IV-rapporten från finska social- och hälsovårdsministeriet rör gränshindret cirka 1500 personer. Säsongsarbetare är den persongrupp som är påverkas mest av gränshindret. Utbetalningarna av sociala trygghetsförmåner till en arbetstagare är beräknade till 1307 EUR/år, och 27078 EUR/år för en familj på fyra personer.

\section{Ekonomiska konsekvenser}

Utbetalningarna av de sociala trygghetsförmånerna som är aktuella i detta fall uppgår till 1307 EUR/år. En arbetstagare som jobbar i Finland i endast tre månader, och således drabbas av fyramånadersregeln, går miste om förmåner till ett värde av 327 EUR, dvs. en fjärdedel av totalbeloppet på 


\section{Beräkningar}

Antagandet är att de 1500 som här nämns, är personer som under ett år har arbetat i Finland under max. fyra månader. Beräkningarna är gjorda utifrån antagandet att den genomsnittliga anställningstiden är tre månader.

Ökade utbetalningar av sociala trygghetsförmåner

Värdering av antalet berörda personer

1500 personer

Sociala trygghetsförmåner till en arbetstagare under tre månader

1307 EUR. Eftersom hindret antas beröra 1500 personer, så sparar den finska staten omkring 490500 EUR per år på att behålla fyramånadersregeln.

\section{Förslag till lösning}

Istället för fyramånadersregeln görs utbetalningen av sociala trygghetsförmåner baserat på en liknande regel för arbetsvillkor som finns i lagen om utkomstskydd för arbetslösa. Rätten till socialförsäkringsförmåner skulle i så fall träda in då personen arbetat minst 18 timmar per vecka och har en lön som motsvarar minimilönen enligt gällande kollektivavtal eller 1154 EUR/månad om det inte finns något kollektivavtal. Alternativt kunde fyramånadersregeln göras om till en enmånadsregel.

\section{Gränshinderrådets arbete med frågan/kommentarer från berörda regeringar \\ Sten Palmgren, Fl:}

Saken togs upp med Folkpensionsanstalten (FPA) och Social- och hälsovårdsministeriet våren 2014. En expertgrupp överlämnade ett betänkande på försommaren 2014 och ett seminarium ordnades. Några konkreta lösningsförslag lades dock inte fram. Gränshinderrådet skickade i april 2014 ett brev till dåvarande social- och hälsovårdsministern med önskemål om att saken förs vidare.

Nya diskussioner fördes hösten 2014 och har även förts under 2015. Frågan kräver ändring av den finska lagstiftningen och är beroende av arbetsmarknadsparternas godkännande.
Social- och hälsovårdsministeriet, FI: En översyn av bestämmelserna om det bostadsbaserade socialskyddet $\mathrm{i}$ internationella situationer ingår i regeringens så kallade spetsprojekt. Inom detta projekt ska bl.a. lagen om tillämpning av lagstiftningen om bosättningsbaserad social trygghet $(1573 / 1993)$ ses över. Den så kallade fyramånadersregeln omfattas av den. Lagändringarna ska träda i kraft senast från ingången av 2019.

Läs mer i Gränshinderdatabasen, granshinder.norden.org, gränshinder nr: 14-008. 


\title{
Flytt för institutionaliserade personer
}

\author{
Enligt den nordiska konventionen om socialt bistånd och sociala \\ tjänster ska de ansvariga myndigheterna samarbeta för att göra det \\ möjligt för äldre eller institutionaliserade personer att flytta till det \\ land där de har starkast personlig anknytning. Detta fungerar inte i \\ praktiken på grund av oklarheter kring betalning och ansvar.
}

Ett prioriterat gränshinder av Ole Stavad, Danmark.

Hindret ingår i avtalet mellan danska Folketinget och danska regeringen.

Hindret kan lösas av socialministerierna och handläggande myndigheter i de nordiska länderna.

Prioriterat sedan 2014

\section{Bakgrund}

Möjligheten för personer som behöver långvarig vård och behandling att flytta från ett nordiskt land till ett annat grundar sig på artikel 9 i den nordiska konventionen om socialt bistånd och sociala tjänster från 1994.

I alla nordiska länder är det kommunerna som är ansvariga för denna vård. Konventionen ger kommunen befogenhet och skyldighet att medverka till flyttningen till ett annat nordiskt land och eventuellt träffa överenskommelse om fördelning av kostnaderna för vård och behandling i de båda länderna. Det finns dock inga sådana direkta regler gällande fördelningen av kostnaderna, i praktiken uppstår därför problem för den enskilde eftersom de ansvariga myndigheterna i ut- och inflyttningsländerna är osäkra på vem som ska stå för flytt- och vårdkostnader.

\section{Vem påverkas}

Hindret påverkar antagligen inte så många, men det har stora konsekvenser för enskilda personer som drabbas.

\section{Förslag till lösning}

Länderna arbetar för att revisionen av den Nordiska konventionen om socialt bistånd och sociala tjänster ska innehålla tydliga regler om ansvarsfördelning och eventuell fördelning av kostnader mellan ländernas myndigheter. Samtidigt bör man utveckla ett bättre informationssystem mellan kommunerna i de nordiska länderna som medför att kommunerna känner till artikel 9 i den nordiska konventionen.

Gränshinderrådets arbete med frågan/Kommentarer från berörda regeringar

Brev fra Socialministeriet af 20.05.15 til Ole Stavad:

Der er taget initiativ til, at der på fælles nordisk plan kan lægges op til klarere vejledning til relevante myndigheder om myndighedernes samarbejde i forbindelse med anmodning fra plejekrævende borgere om flytning til et andet nordisk land. Med henblik på at afklare, hvorvidt der er behov for en revision af Den Nordiske Konvention om Social Bistand og Sociale Tjenester, har arbejdsgruppen i foråret 2013 igangsat 


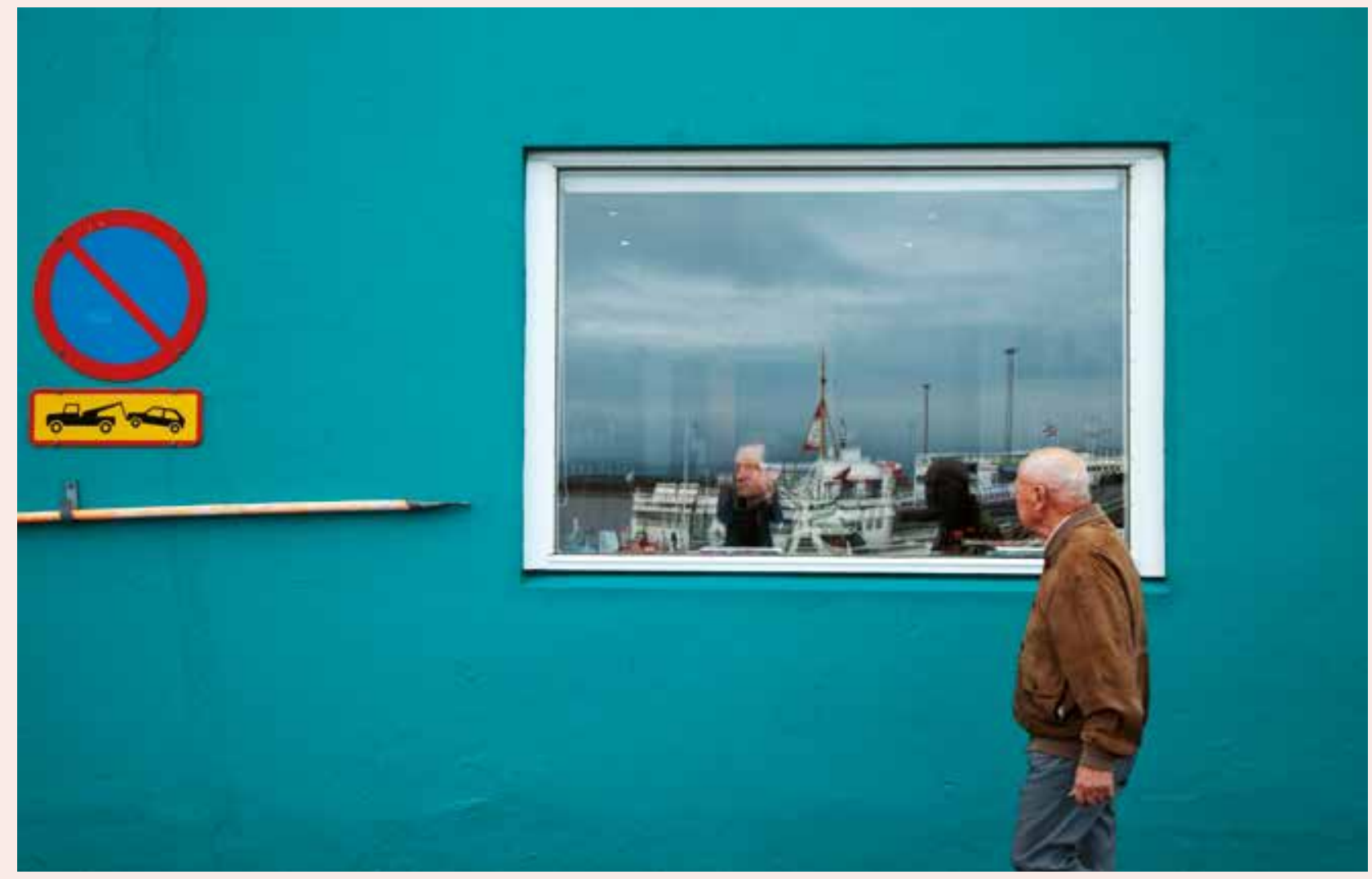

en analyse, hvor Bistandskonventionens bestemmelser ses i sammenhæng med EU- og international ret, samt de nordiske landes nationale lovgivning. Arbejdet hermed forestås af en ekstern ekspert. På baggrund af den nu færdige analyse skal der i 1. halvår af 2015 træffes beslutning om en mulig revision af konventionen.
På bakgrund av den nu genomförda analysen av den Nordiska konventionen om socialt bistånd och sociala tjänster (Biståndskonventionen) beslutade ÄK-S den 27-28 maj 2015 att en revision skall göras.

ÄK-S beslutade 3-4 nov. att tillsätta en revisionsgrupp som under 2016 skall utarbeta förslag till ny konventionstext. MR-S väntas 2017 ta del av förslaget och besluta om en eventuell revision.

Läs mer i gränshinderdatabasen, granshinder.norden.org, gränshinder nr: 14-104. 
Hinder på
skatteområdet

Hinder på
skatteområdet

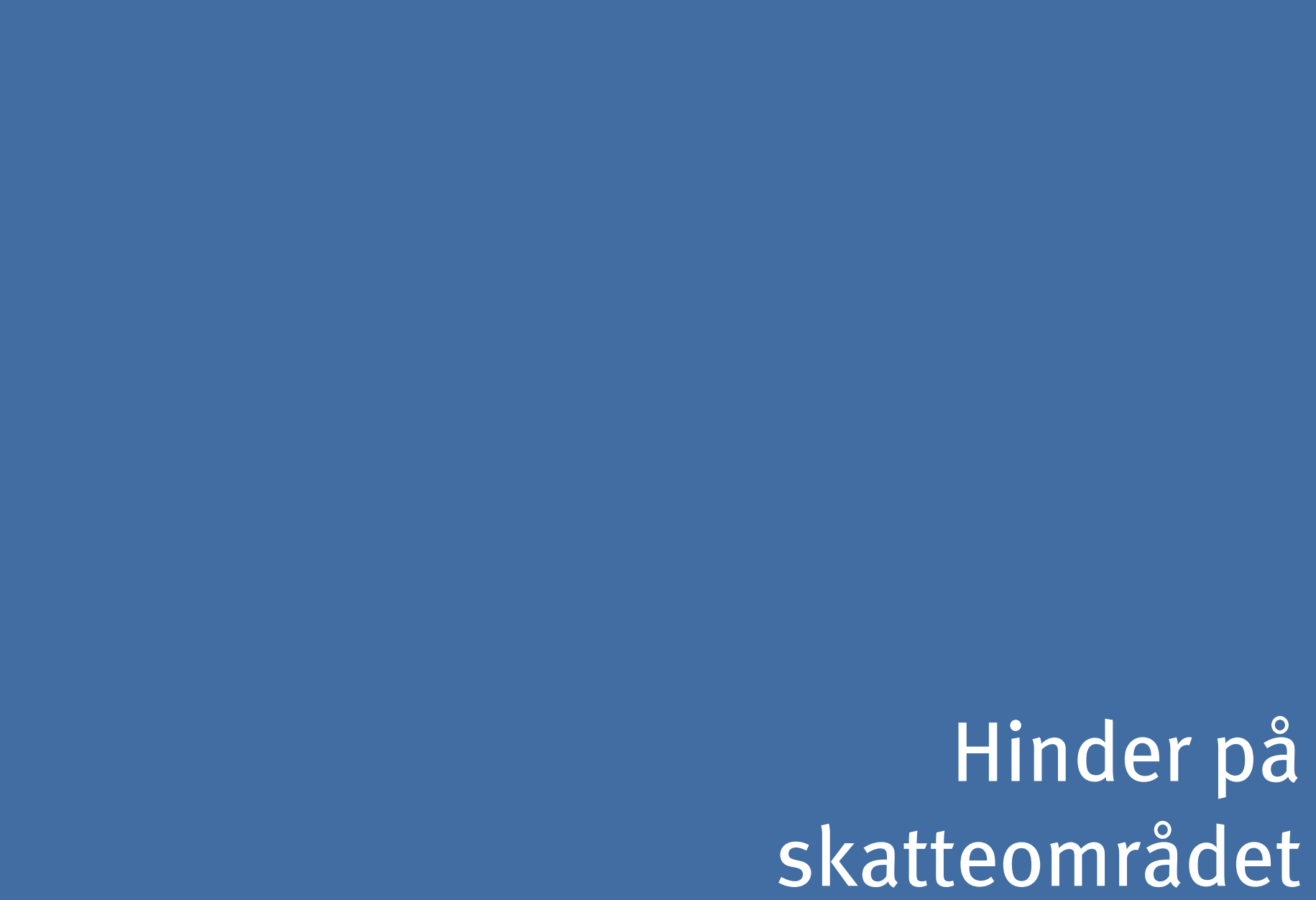

\section{t \\ a}

(n)

-

(

(

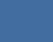

(2) 


\title{
Dubbelbeskattning Grönland och Sverige/Finland
}

\author{
Grönland ingår inte i det nordiska avtalet om dubbelbeskattning. Det måste \\ därför för varje land finnas ett avtal om undvikande av dubbelbeskattning.
}

Ett prioriterat gränshinder av Christian Wennecke, Grönland.

Hindret kan lösas av Naalakkersuisut/Inatsisartut och Finansdepartementen.

Prioriterat sedan 2014

\section{Bakgrund}

Det finns för närvarande inga skatteavtal för undvikande av dubbelbeskattning mellan Grönland, Finland och Sverige, i likhet med dem som finns med till exempel Danmark och Norge. Detta leder till osäkerhet om beskattning av inkomster för personer som flyttar mellan länderna och det minskar incitamentet att flytta för att arbeta, studera, bosätta sig eller liknande.

Departementet för finans och inrikesfrågor samt Skattestyrelsen på Grönland är ansvariga för området.

\section{Vem påverkas}

Hindret påverkar Finland, Sverige och Grönland. Antalet personer som drabbas är sannolikt få.

\section{Ekonomiska konsekvenser}

Om de skattemässiga konsekvenserna av att flytta mellan Grönland, Finland och Sverige blir lösta kommer det troli- gen att öka viljan att röra sig mellan de länderna i positiv riktning.

\section{Förslag till lösning}

Två lösningar har föreslagits:

a) Bilaterala avtal om dubbelbeskattning med Sverige och Finland, i likhet med de avtal som finns med övriga nordiska länder.

b) På Gränshinderrådets kick-off diskuterades hindret och frågan om varför Grönland inte är med $i$ det gemensamma nordiska avtalet om dubbelbeskattning. Avtalet är under revision och Grönland föreslås överväga anslutning till avtalet.

\section{Gränshinderrådets arbete med frågan/kommentarer från berörda regeringar \\ Sten Palmgren, FI: \\ Högsta förvaltningsdomstolen i Finland är i gång med att behandla ett besvär där det centrala är att utreda begreppet "främmande stat" $i$ den ovan nämn-}

da avräkningslag. Om tolkningen av begreppet breddas genom HFD:s beslut från den nuvarande, kan problemet med dubbelbeskattning avhjälpas även utan ett dubbelbeskattningsavtal.

\section{Finansdepartementet, SE:}

I Sverige finns ensidiga regler för undanröjande av dubbelbeskattning som är tillämpliga i förhållande till Grönland. Det är inte känt att det skulle finnas omfattande problem med dubbelbeskattning i förhållande till Grönland.

Christian Wennecke, GL:

Skattestyrelsen i Grønland har redegjort for at det er muligt at opnå en skattekredit i de tilfælde hvor man ville være blevet beskattet i begge lande.

\section{Finansdepartementet Grønland:}

Har en borger eller virksomhed hjemmehørende i et nordisk land en indkomst $i$ et andet nordisk land, som bliver beskattet i det andet nordiske land, kan 
den betalte skat trækkes fra den skat borgeren eller virksomheden skal betale i sit hjemland.

For Grønlands vedkommende indeholder indkomstskattelovens § 69 en sådan kreditbestemmelse. Bestemmelsen sikrer grønlandske borgere og virksomheder mod at blive dobbeltbeskattet af indkomst fra aktiviteter i f.eks. Sverige og Finland.

Grønlandske borgere og virksomheder med økonomiske aktiviteter i Sverige eller Finland bliver med andre ord ikke fuldt beskattet i begge lande. Svenske eller finske borgere og virksomheder med aktiviteter i Grønland bliver heller ikke fuldt beskattet i både Grønland og Sverige henholdsvis Finland. For den enkelte borger eller virksomhed har en dobbeltbeskatningsaftale som følge af de forskellige landes kreditbestemmelser ofte ingen eller kun en mindre $ø$ konomisk betydning.
En dobbeltbeskatningsaftale har til formål at fordele beskatningsretten mellem 2 lande. En aftale kan f.eks. gå ud på, at kun det ene land må beskatte en indkomst, mens det andet land skal afstå fra at beskatte denne indkomst. En aftale kan med andre ord få stor økonomisk betydning for begge lande. Det er derfor vigtigt, at en dobbeltbeskatningsaftale indgås på fair vilkår for begge lande.

Grønland vil som nettoimportør af arbejdskraft og kapital som udgangspunkt miste mere ved en dobbeltbeskatningsaftale end landet vil vinde. Når det alligevel kan være økonomisk interessant at undersøge mulighederne for at indgå en dobbeltbeskatningsaftale med et andet land, skyldes det hensynet til at fremme investeringer fra det andet land i Grønland og udveksling af arbejdskraft mellem de 2 lande. Det forudsætter dog, at der er eller i hvert fald er udsigt til, at investeringerne og udvekslingen af arbejdskraft har tilstrækkeligt volumen.

Grønland tog bl.a. i forlængelse af opstarten af en svensk ejet olivinmine i Grønland kontakt til de svenske skattemyndigheder med henblik på forhandling af en dobbeltbeskatningsaftale. Kontakten resulterede ikke i, at der blev optaget forhandlinger. Omkring 2010 anmodede Grønland på ministerniveau om indledning af dobbeltbeskatningsforhandlinger. De herefter indledte forhandlinger viste en stor afstand mellem de 2 landes ønsker til en dobbeltbeskatningsaftale. Fra svensk side blev der givet udtryk for, at Grønlands ønske om en dobbeltbeskatningsaftale vil indgå i Sveriges øvrige prioritering af dobbeltbeskatningsaftaleforhandlinger eller genforhandlinger af samme. Der har ikke siden været vist svensk interesse for at genoptage forhandlingerne. 


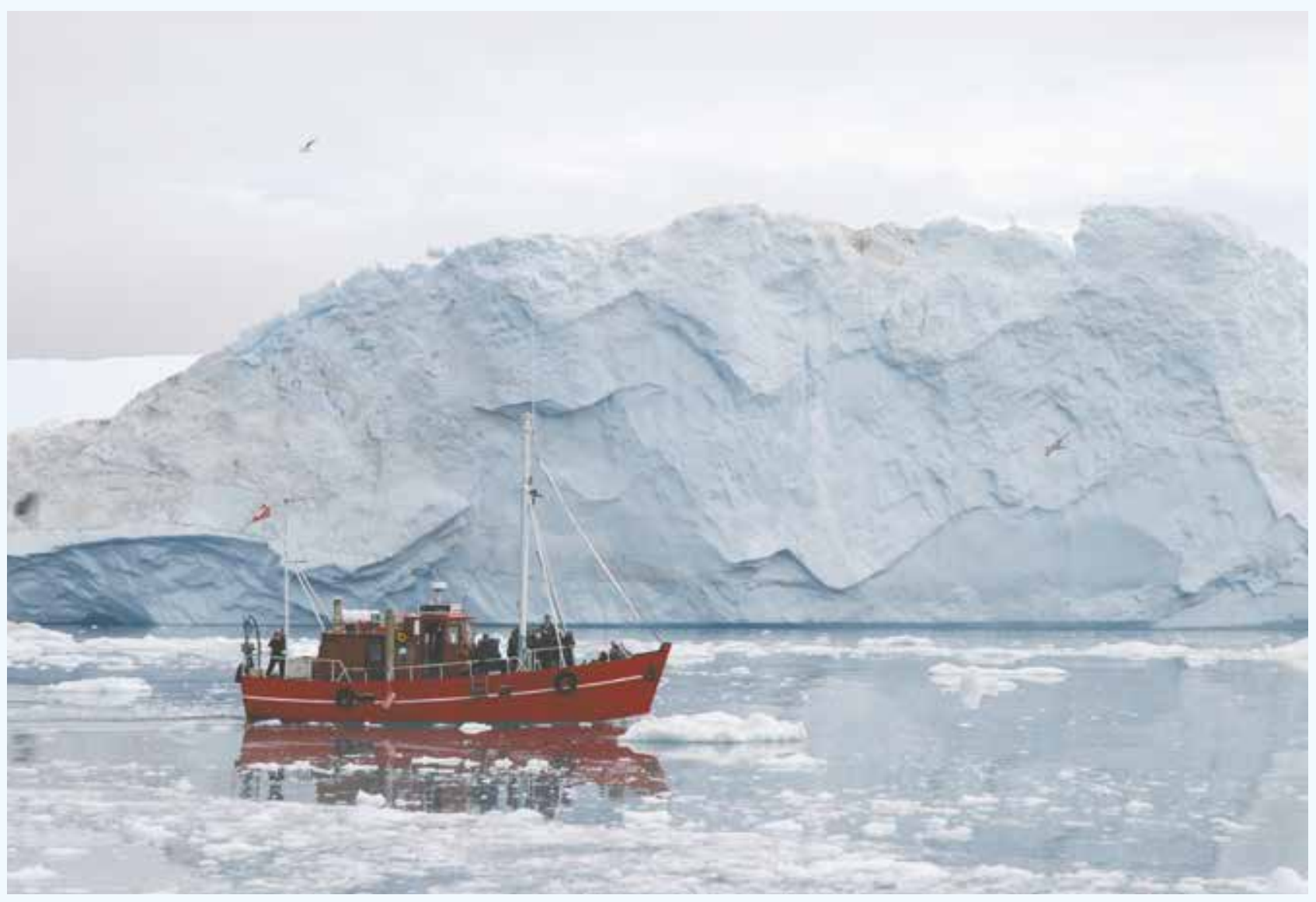

Som det også fremgår af opgørelsen på rapportens side 10 er det på nuværende tidspunkt meget begrænset, hvor mange borgere der årligt flytter mellem Grønland og Sverige henholdsvis Grønland og Finland.

Finansdepartementet er heller ikke bekendt med, at der aktuelt er tale om væsentlige direkte svenske eller finske investeringer i Grønland eller grønlandske investeringer i Sverige eller Finland. Dette er formentlig også baggrunden for, at en dobbeltbeskatningsaftale med Grønland ikke hidtil har været prioriteret fra svensk side.

Efter Finansdepartementets opfattelse, bør prioritering af dobbeltbeskatningsaftaler med Sverige eller Finland eller for den sags skyld med andre lande foretages efter en samlet afvejning af fordele og ulemper, og kun hvis der er udsigt til et for Grønland fair resultat, bør der tages skridt til at prioritere sådanne aftaler.
Departementet beklager, at disse synspunkter tilsyneladende ikke har været forklaret tilstrækkeligt tydeligt tidligere og derfor ikke er inddraget ved udformning af rapporten.

Läs mer i Gränshinderdatabasen, granshinder.norden.org, gränshinder nr: 14-177. 


\title{
Beskattning av dansk kapitalpension
}

\author{
Danska kapitalpensioner påläggs en avgift vid utbetalningen. Avgiften \\ omfattas inte av det nordiska dubbelbeskattningsavtalet vilket medför en risk \\ för dubbelbeskattning om kapitalpensionen utbetalas i ett annat nordiskt land.
}

Ett prioriterat gränshinder av Ole Stavad, Danmark.

Hindret finns med i det avtalet mellan det danska Folketinget och regeringen.

\section{Bakgrund}

I Danmark tas det inte ut någon skatt på kapitalpensioner, istället betalar mottagaren en avgift i samband med utbetalningen. Om pensionen tas ut exempelvis i Norge anses den därför vara obeskattad vilket innebär att det norska skatteverket kan beskatta kapitalpensionen utan att beakta den avgift som redan betalats i Danmark. I praktiken blir konsekvensen en slags dubbelbeskattning av kapitalpensionen eftersom situationen inte täcks av det nordiska dubbelbeskattningsavtalet.

\section{Vem påverkas}

Problemet påverkar troligen ett mindre antal personer som rör sig över gränserna.

\section{Förslag till lösning}

Säkra så att det endast ett land kan ta ut skatt på en kapitalpension, till exempel genom ett avtal om att endast ursprungslandet, som har beviljat personen som har sparat i en kapitalpension avdrag i förbindelse med besparingen, har rätt att ta ut en avgift/ skatt på kapitalpension.

Att man mellan länderna i detta fall likställer definitionen avgift med skatt.

\section{Gränshinderrådets arbete med frågan/kommentarer från berörda departement Ole Stavad, DK: \\ Dansk kapitalpension er under hurtig afvikling. Der kan ikke oprettes nye ordninger og ikke indskydes på}

eksisterende. Langt hovedparten er allerede ophævet. Der er kun forholdsvis få ordninger tilbage. Jeg har ikke modtaget henvendelser om problemer med dobbeltbeskatning de seneste ca. 2 år. På et møde med skatteministeriet den 13. november 2015 fik jeg bekræftet, at Skatteministeriet heller ikke, i meget lang tid, har hørt om problemet, efter man fra svensk side løste problemet med danskere bosiddende i Sverige. På den baggrund anbefales det at afskrive sagen som løst.

Läs mer i gränshinderdatabasen, granshinder.norden.org, gränshinder nr: 14-154. 


\title{
Rutiner för skatteinbetalning för äkta gränsgångare
}

\author{
Personer och arbetsgivare som bor och verkar i de gränskommuner i Sverige \\ och Finland som gränsar mot Norge upplever problem med skatteinbetalningar.
}

Ett prioriterat gränshinder av Svein Ludvigsen, Norge och Annika Hahn-Englund, Sverige.

Hindret kan lösas av norska finansdepartementet, svenska finansdepartementet och finska finansministeriet.

Prioriterat sedan 2014

Löst

Gällande rutiner för skattehantering i Norge är löst

Gällande avdrag av trygdeavgiften i den finsk/svenska deklarationen - ej löst

\section{Bakgrund}

Personer som bor i en gränskommun, arbetar i en av det andra landets gränskommuner och omfattas av gränsgångaravtalet ska skatta till sin boendekommun. Dessa personer ska själva sköta sina skatteinbetalningar på tidigare lämnade uppgifter till Skatteförvaltningen. För den person som har en ojämn inkomst blir det synnerligen komplicerat att veta hur mycket man ska betala in i förväg.

En person som är en gränsgångare enligt skatteavtalet betalar en social- försäkringsavgift (trygdeavgift) på $8,2 \%$. Denna räknas inte som en skatt utan som en avgift vilket genererar ett avdrag på den finska/svenska deklarationen. Frågan är om inte detta är en dubbelbeskattning som borde ge en skatteavräkning i stället.

En arbetsgivare kan även den bli drabbad av extra administrativt arbete. Om personen ovan även arbetar i en icke gränskommun erläggs skatten för denna inkomst till Norge. Arbetsgivaren måste då upprätta två lönespecifikationer.

\section{Ekonomiska konsekvenser}

En person som är bosatt i Strömstad i Sverige och arbetar heltid i grannkommunen Halden i Norge, med en månadslön på 45000 NOK vilket motsvarar en årsinkomst på 606700 SEK, förlorar cirka 24000 NOK per år eftersom socialförsäkringsavgiften (trygdeavgiften) avräknas mot bruttoinkomsten och inte mot skatten. Närmare beräkningar finns nedan. 


\section{Beräkningar}

\begin{tabular}{|lrr|}
\hline & & $\begin{array}{r}\text { Avräkning för } \\
\text { Trygdeavgift efter skatt }\end{array}$ \\
Bruttoinkomst/lön & Dagsläge & 606700 SEK \\
Avdrag & 606700 SEK \\
Grundavdrag & 49750 SEK & 13100 SEK \\
Förvärvsinkomst & 13100 SEK & 593600 SEK \\
Beskattning (inkl jobbskatteavdrag) & 543850 SEK & 192976 SEK \\
Avräkning för trygdeavgift & 167578 SEK & 49750 SEK \\
Total skatt & 167578 SEK & 143226 SEK \\
\hline Nettoinkomst & 439122 SEK & 463474 SEK \\
\hline Skillnaden mellan dagsläget och avräkning av socialförsäkringsavgiften & & 24352 SEK
\end{tabular}

\section{Förslag till lösning}

- Ett förslag kan vara att samtliga gränspendlare, oavsett om de bor och arbetar mellan två gränskommuner eller inte, blir både socialförsäkrade (betalar trygdeavgift) och skattskyldiga i antingen i bosättningslandet eller i arbetslandet.

- Ett annat förslag är att personen är fortsatt skattepliktig i Sverige och att socialförsäkringstillhörigheten tillhör Norge, men att personen inte inbetalar socialförsäkringsavgiften (trygdeavgiften).
- Ett tredje förslag är att socialförsäkringsavgiften (trygdeavgiften) dras av från den svenska beräknade skatten, se närmare beräkningar nedan.

\section{Gränshinderrådets arbete med frågan/kommentarer från berörda regeringar}

Svein Ludvigsen, NO:

Det norske Finansdepartementet opplyser at det er iverksatt nye rutiner for arbeidstakere og arbeidsgivere. FID legger til grunn at de svenske og finske grensegjengerne som arbeider $\mathrm{i}$ Norge ikke lenger vil oppleve særskilte problemer knyttet til norske rutiner for skatteinnbetaling m.m. Grensehinderrådet anser derfor at dette hinderet er løst, hvad angår Norge.

Frågan anses löst från norsk sida. Gränshinderrådet ska överväga att undersöka behovet av ändringar i det nordiska dubbelbeskattningsavtalet.

Läs mer i gränshinderdatabasen, granshinder.norden.org, gränshinder nr: 14-056. 


\title{
Problem med fast anställda kulturarbetare i Sverige
}

\author{
Beskattning av kulturarbetare i det nordiska skatteavtalet regleras i bestämmelsen \\ för "artister och sportutövare". Inkomster som faller in under den artikeln får i \\ gränsöverskridande fall beskattas i både Danmark och Sverige. Förekommande \\ dubbelbeskattning undanröjs genom avräkning i hemviststaten. I fråga om andra \\ grupper av arbetstagare undanröjs däremot dubbelbeskattning i stor utsträckning \\ genom att inkomsterna helt undantas i hemviststaten, med följd att beskattning \\ bara sker i ett land, arbetslandet.
}

Ett prioriterat gränshinder av Ole Stavad, Danmark samt MR-K.

Hindret kan lösas av det danska Skatteministeriet och svenska Finansdepartementet.

\section{Bakgrund}

Reglerna i det nordiska skatteavtalet avseende "artister och idrottsmän" innebär att denna kategori av arbetstagare alltid beskattas i både Sverige och Danmark, med avräkning i hemviststaten av den skatt som betalats i arbetslandet. Detta innebär att kulturarbetare som bor i Danmark och arbetspendlar till Sverige normalt kommer att beskattas på den nominellt högre danska inkomstskattenivån. Andra löntagare som pendlar på samma sätt betalar i allmänhet endast betalar skatt i Sverige. Problemet är till följd av den lägre svenska nivån på inkomstskatten inte av någon större betydelse för kulturarbetare som bor i Sverige och arbetar i Danmark.
I Sverige finns så kallad "artistskatt" eller A-SINK för utomlands bosatta artister. A-SINK är en definitiv källskatt på $15 \%$ på bruttobeloppet och inbetalas av arrangören/arbetsgivaren. Danmark har ingen motsvarande specifik artistskatt. Andra grupper av löntagare som pendlar från Danmark till en fast anställning på den skånska sidan betalar SINK-skatt med $20 \%$ på bruttobeloppet. Då "artister och idrottsmän" alltid får beskattas också i Danmark (med avräkning för erlagd A-SINK) kommer deras inkomst att beskattas på den danska inkomstskattenivån (dock nettobeskattning) med upp till $40 \%$. I förhållande till de andra grupperna av löntagare undantas däremot inkomsterna i Sverige i regel helt från beskattning i Danmark, vilket innebär att de endast betalar svensk SINK-skatt.

\section{Vem påverkas}

Gränshindret rör cirka 100 fast eller tillfälligt anställda institutionsmusiker.

\section{Ekonomiska konsekvenser}

En symfoniker med en månadslön på 30000 SEK skulle få en ökad årsinkomst på 72000 SEK om hon/han skulle beskattas med vanlig SINK. Årsinkomsten efter skatt skulle då stiga från 216000 SEK till 288000 SEK. Närmare beräkningar finns nedan.

\section{Förslag till lösning}

Ett förslag till lösning som Gränshinderrådet ser som tänkbart är att Sverige och Danmark inom ramen för det Nordiska skatteavtalet kommer överens om 


\section{Beräkningar}

Beskattning utifrån A-SINK (som det ser ut i dag)

Årslön för symfoniker med SEK 30.000 månadslön

360000 SEK

Svensk skatt $15 \%$

54000 SEK

Dansk skatt $25 \%$

90000 SEK

Nettolön per år

216000 SEK

Beskattning utifrån vanlig SINK (efter de föreslagna ändringarna)

Årslön för symfoniker med SEK 30.000 månadslön

360000 SEK

Svensk skatt $20 \%$

72000 SEK

Dansk skatt $0 \%$

Nettolön per år

288000 SEK

Total löneökning om beskattning övergår till vanlig SINK

72000 SEK

att art. 17 inte ska tillämpas på artister med fasta anställningar. Det blir då istället med automatik beskattning enligt art. 15 vilket innebär att metoden exempt blir tillämplig (i fråga om Danmark dock endast för de personer som tillhör svensk socialförsäkring). Exempt, även kallad undantagsmetoden, innebär att inkomst helt eller till viss del undantas från beskattning i en stat, oftast för att den beskattas i en annan stat. Den bästa tekniska lösningen får diskuteras fram, antingen en definition på fast anställning kopplat till kontrakt eller en generell tidsgräns på över sex månaders arbete för samma arbetsgivare.

En annan möjlighet som man ser från Gränshinderrådets sida är att fast anställda kulturarbetare i Sverige betalar vanlig SINK-skatt istället för att betala
A-SINK som turnerande musiker. Detta kommer att innebära att de inte kommer att mötas av krav på ytterligare beskattning i Danmark.

Ytterligare en möjlighet är att Danmark i sin interna rätt behandlar gränspendlande artister som tillhör svensk socialförsäkring på samma sätt som andra anställda som tillhör svensk socialförsäkring och även undantar inkomster enligt artikel 17 från beskattning i Danmark i dessa fall.

\section{Gränshinderrådets arbete med frågan/kommentarer från berörda regeringar}

Finansdepartementet, SE:

Frågan beror ytterst på i vilken utsträckning Danmark är villigt att undanta de aktuella inkomsterna från beskattning i
Danmark i förhållande till personer med hemvist där. Förutom grundkriteriet att personerna måste tillhöra svensk socialförsäkring, verkar denna bedömning vara avhängig av om beskattningen av inkomsterna i Sverige är på en acceptabel nivå. I nuläget ses såvitt vi kan förstå beskattning enligt A-SINK som för låg beskattning varför undantag inte medges, medan nivån för SINK är acceptabel med följd att undantag medges. Att genom en särskild reglering i skatteavtalet göra artikel 15 istället för artikel 17 tillämplig för den aktuella gruppen av arbetstagare torde inte påverka den bedömningen. Personerna i fråga skulle alltjämt vara beskattade enligt A-SINK i Sverige. Det är heller inte acceptabelt att Sverige ska ändra den generella svenska lagstiftningen för SINK och A-SINK, i syfte att en liten 
grupp individer ska erhålla undantag från beskattning i Danmark.

\section{Ole Stavad, DK:}

Siden seneste afrapportering for 2014 er der fremkommet nye oplysninger som betyder, at problemet ikke alene kan øøses gennem regelændringer i Sverige, men også forudsætter ændringer i den danske skattelovgivning.

På et møde med den danske skatteminister den 13. november 2015 blev det aftalt, at Skattteministeriet på ny vil vurdere sagen og vende tilbage med et svar på eventuelt nye initiativer inden udgangen af 2015.

Man har ikke fra svensk side ønsket at tage initiativi sagen. På den baggrund gjorde jeg det klart for skatteministeren, at såfremt der skal ske fremskridt i sagen, vil det forudsætte et dansk initiativ. På den baggrund må vi afvente tilbagemelding fra Skatteministeriet for at kunne vurdere, om der er politisk vilje til at finde en løsning på et problem, som omfatter ganske få mennesker, men som oplever en urimelig skattemæssig behandling i forhold til øvrige i et sammenligneligt ansættelsesforhold.

Läs mer i gränshinderdatabasen, granshinder.norden.org, gränshinder nr:14-066.

\section{Beräkningar}

Beskattning utifrån A-SINK (som det ser ut i dag)

Årslön för symfoniker med SEK 30.000 månadslön

360000 SEK

Svensk skatt $15 \%$

54000 SEK

Dansk skatt $25 \%$

90000 SEK

Nettolön per år

216000 SEK

Beskattning utifrån vanlig SINK (efter de föreslagna ändringarna)

Årslön för symfoniker med SEK 30.000 månadslön

360000 SEK

Svensk skatt $20 \%$

72000 SEK

Dansk skatt $0 \%$

Nettolön per år

288000 SEK 


\section{Frågor om dubbelbeskattningsavtalet $\mathrm{i}$ förhållande till studiestöd}

\section{Olika regler gällande beskattningen av studiestöd kan leda till både för- och nack- delar för personer beroende på var personen är bosatt och var studierna bedrivs.}

Ett prioriterat gränshinder av Ole Stavad, Danmark.

Hindret ingår i avtalet mellan det danska Folketinget och regeringen.

Hindret kan lösas av det danska skatteministeriet och svenska finansdepartementet.

Prioriterat sedan 2014

\section{Lösningen på problemet förutsätter en ändring i det nordiska dubbelbeskattningsavtalet. Gränshinderrådet har därför beslutat att inte arbeta vidare med frågan.}

\section{Bakgrund}

Det danska studiestödet anses vara beskattningsbar inkomst till skillnad från den svenska motsvarigheten. Med andra ord är danskt studiestöd beräknat som ett bruttobelopp medan det svenska är ett nettobelopp.

Skillnaderna i beskattningen medför, att danskt studiestöd till en student vid en dansk utbildningsinstitution som är bosatt i Sverige inte beskattas i varken Danmark eller Sverige. Studenten får därmed ett högre belopp än medstudenterna som är bosatta i Danmark.

Om det istället rör sig om svenskt studiestöd till en student vid en svensk utbildningsinstitution som är bosatt $i$ Danmark så kommer studiestödet att beskattas i Danmark. Studenten får därmed ett lägre belopp än medstudenterna som är bosatta i Sverige.
Gränshindret kan rimligtvis uppstå i alla regioner där det finns skillnader mellan beskattningen av studiestöd, men torde främst aktualiseras i Öresundsregionen.

\section{Vem påverkas}

Detta hinder påverkar främst personer i Danmark och Sverige.

Problemet påverkar troligen ett större antal studerande som rör sig över de nordiska gränserna.

\section{Förslag till lösning}

Länderna förhandlar och genomför en lösning, så att de studerande inte upplever stora negativa svängningar i sina ekonomier genom att flytta till ett annat land.

\section{Gränshinderrådets arbete med frågan/kommentarer från berörda regeringar \\ Ole Stavad, DK:}

Løsning af problemet forudsætter en ændring af Den Nordiske Dobbeltbeskatningsaftale (DBO). Der er fra regeringsside udtrykt enighed om, at problemet skal løses ved først givne lejlighed, hvor Den Nordiske DBO bliver ændret. Dette er senest bekræftet på et møde med den danske skatteminister den 13.11.2015. Sagen er dog for beskeden til alene at begrunde en ændring af DBO'en. På den baggrund kan Grænsehindringsrådet ikke foretage sig mere i sagen, men må afvente næste gang der sker ændringer i den nordiske DBO.

På denna grund avskriver Gränshinderrådet ärendet som avklarat men inte löst.

Läs mer i gränshinderdatabasen, granshinder.norden.org, gränshinder nr: 14-156. 


\title{
Norsk intern skattepraxis försvårar utförande av uppdrag i byggbranschen
}

\author{
Företag inom exempelvis byggbranschen, upplever stora administrativa \\ problem i samband med tillfälliga uppdrag i Norge. Detta även om \\ uppdraget endast varar några månader och är av engångskaraktär.
}

Ett prioriterat gränshinder av Svein Ludvigsen, Norge och Ole Stavad, Danmark.

Hindret kan lösas av Finansdepartementet i Norge.

Prioriterat sedan 2015

\section{Bakgrund}

Företagen upplever att de norska skattemyndigheterna administrerar utifrån interna norska regler och inte utifrån det nordiska skatteavtalet. För danska företag är konsekvensen att två av tre ger upp att ge sig in på den norska marknaden - antingen omedelbart eller inom det första året.

Principerna i det nordiska skatteavtalet innebär att exempelvis en dansk entreprenör som utför ett tillfälligt bygguppdrag blir skattepliktig i Norge först när det enskilda entreprenörsprojektet överstiger 12 månader. En tillfälligt utstationerad medarbetare blir skattepliktig först när han/hon vistats längre än 183 dagar i landet under loppet av 12 månader. Dessa två viktiga regler i skatteavtalet ska främja den fria rörligheten i Norden.

Dessa två grundprinciper åsidosätts dock av intern norsk skattepraxis som gör att utstationerade tvingas ansöka om norskt skattekort från dag ett. Dessutom ska både företaget och den anställde lämna en norsk självdeklaration - även i de fall där det bara rör sig om ett enstaka kortvarigt projekt $i$ Norge.

\section{Vem påverkas}

Företag som beger sig till Norge för att utföra uppdrag i byggbranschen.

\section{Gränshinderrådets arbete med frågan/kommentarer från berörda regeringar \\ Ole Stavad, DK: \\ Det er i sagens natur det enkelte land der selv beslutter sine administrative procedurer. Alligevel kan det være hensigtsmæssigt, at etablere et nordisk samarbejde om en så enkel procedure}

og administration som muligt, da unødigt bureaukrati kan stå i vejen for en effektiv konkurrence og hæmme vækst og udvikling. Ligeledes er der en række fortolkningsspørgsmål i forhold til Den Nordiske Dobbeltbeskatningsoverenskomst (DBO) om f.eks. fast driftsted, transfer pricing m.v.

På den baggrund har jeg på et møde med den danske skatteminister den 13. november 2015 opfordret til, at man helt generelt etablerer en nordisk arbejdsgruppe inden for skat, som kan drøfte og aftale hensigtsmæssige administrative procedurer, fortolkning af den nordiske DBO, anvendelse af digital kommunikation osv.

Skatteministeren har lovet at undersøge mulighederne og overveje noget sådant, hvorefter man vil vende tilbage inden udgangen af 2015. 


\section{Finansdepartementet, NO:}

"Plikten til å levere selvangivelse følger av ligningsloven paragraf 4-2 og er pålagt den som har inntekt eller formue som er skattepliktig etter norsk skattelovgivning, bortsett fra kildeskatt på aksjeutbytte. Det er i forskrift 16.02.2001 $\mathrm{nr} 155$ fastsatt noen fritak fra selvangivelsesplikten for visse grupper skattytere, men det gjelde ingen alminnelig fritak for selvangivelsesplikt for tilfeller der Norge etter en skatteavtale har fraskrevet seg beskatningsrett. Lønnsoppgaveplikten følger av ligningsloven paragraf 5-2 og er nærmere regulert i samleforskrift 17.09.2013 om tredjeparters opplysningsplikt. Det er ikke gjort unntak i lønnsoppgaveplikten for utbetalinger som er fritatt for skatteplikt etter skatteavtale. Skatteavtalene regulerer ikke sekundærplikter etter skattelovgivningen slik som for eksempel plikten til å levere selvangivelse eller lønnsoppgave. Dette har gode grunner for seg; Hvorvidt fritak etter en skatteavtale gjelde må vurderes av skattemyndighetene når skatteplikt er pålagt etter skattelovgivningen; det kan ikke være opp til skattyteren selv å unnlate å levere selvangivelse eller lønnsoppgave under en pretensjon om at skatteavtale fritar for skatteplikt $i$ det enkelte tilfelle. Alle skattytere som forventes å få trekkpliktig inntekt av betydning må i samsvar med skattebetalingsloven paragraf 5-1 få utstedt skattekort fra skattekontoret. Finansdepartementet foreslår at dette punktet ikke tas med videre som et prioritert grensehinder."

\section{Grensehinderrådet kommentar:}

Saken kan ikke ansees som avsluttet med bakgrunn i det initiativ Finansministeriet i Danmark har tatt om å søke etablert en nordisk arbeidsgruppe innen skatt.

Detta hinder framlades på tillväxtkonferensen på Børsen den 30. april 2016 som ett av femton prioriterade hinder från arbetsmarknadens parter i Norden.

Läs mer i Gränshinderdatabasen, granshinder.norden.org, gränshinder nr: 15-005. 


\title{
Beskattning av utländska pensioner i bosättningslandet
}

\author{
Artikel 18 i det nordiska dubbelbeskattningsavtalet ändrades med verkan \\ från och med 2009 bland annat i förhållande till beskattningen av pensioner \\ (och livräntor). Ändringen medför att personer som bor i ett nordiskt land och \\ tar emot pension från ett annat nordiskt land i enstaka fall blir beskattade \\ högre än om personen hade bott i utbetalningslandet.
}

Ett prioriterat gränshinder av Annika Hahn Englund, Sverige och Ole Stavad, Danmark.

Hindret kan lösas av de nordiska skatteministerierna och finansdepartementen.

Prioriterat sedan 2015

\begin{abstract}
Bakgrund
Innan ändringen använde man sig av den så kallade exempt-metoden i fråga om pensioner, där bosättningslandet helt avstod från att beskatta dessa om de utbetalats från ett annat nordiskt land. Numera används istället den så kallade credit-metoden där bosättningslandet beskattar pensionerna på samma sätt som pensioner som intjänats i det landet, men beviljar avräkning för skatterna som erlagts för pensionerna i fråga i utbetalningslandet. $0 m$ beskattningen av pensionerna i det nya bosättningslandet är högre än i utbetalningslandet (det tidigare bosättningslandet) betalas alltså högre skatt än den i utbetalningslandet, vilket inte kunde inträffa enligt de tidigare reglerna.
\end{abstract}

Pensionerna har emellertid ursprungligen beräknats på basis av skattesystemet $\mathrm{i}$ utbetalningslandet. De enskilda pensionsmottagarnas pensionsinbetalningar kommer under årens lopp $\mathrm{i}$ länderna att beskattas olika dels när det gäller avdrag för inbetalningar, dels vad gäller den löpande avkastningen. En relativt låg pensionsutbetalning från ett land är alltså vanligtvis uttryck för att det inte har beviljats avdrag vid inbetalning och/eller att det dras högre skatt eller avgift från den löpande avkastningen av det kapital som ska utgöra underlag för utbetalningen. Som en följd av detta kommer det vanligtvis att vara fråga om en lägre beskattning av den utbetalade pensionen.
När denna pension sedan betalas ut till och beskattas i ett land där pensionsinbetalningar har varit avdragsgilla och beskattningen av den löpande avkastningen låg, men där beskattningen av utbetalade pensioner är högre, kommer den sammanlagda skatten på pensionen att bli väsentligt högre. Sammantaget kan det innebära en förlust som kan leda till att den enskilde blir avskräckt från att flytta till ett annat nordiskt land.

\section{Vem påverkas}

Personer som bor i ett nordiskt land och som får pension utbetalad från ett annat nordiskt land. 


\section{Gränshinderrådets arbete med frågan/kommentarer från berörda regeringar \\ Ole Stavad, DK:}

Fra dansk side afviser man at ændre på de nuværende beskatningsregler. Begrundelsen for at fastholde "kreditmetoden” er, at de pågældende pensionister med den aftalte kreditmetode betaler skat helt på linje med alle øvrige danske borgere bosiddende i Danmark. Man er socialt sikret i Danmark og Danmark anvender principielt og konsekvent kreditmetoden i sine dobbeltbeskatningsaftaler - helt på linje med anbefalingerne i OECD's modelkonvention. På et møde med den danske skatteminister og ministeriets embedsmænd den 13. november 2015 blev ovennævnte holdning bekræftet og med en klar afvisning af at ændre på gældende regler.
Spørgsmålet har også tidligere været rejst i forhold til Finansministerrådet, hvor jeg på vegne af det tidligere Grænsehindringsforum deltog $i$ et møde med finansministrene, hvor spørgsmålet blev forelagt ministrene. Efter en udredning og drøftelse blev beslutningen også her, at man ikke ønskede at ændre på de aftalte regler for beskatning af udenlandske pensioner. På den baggrund forekommer det udsigtsløst at fortsætte diskussionen og Grænsehindringsrådet bør afskrive sagen.

\section{Finansdepartementet, SE:}

Vid omförhandlingen av det nordiska skatteavtalet 2008 kom länderna överens om att övergå till creditmetoden för undanröjande av dubbelbeskattning $i$ fråga om pensioner. Genom ändringen får varje nordiskt land beskatta personer med hemvist i det landet och som har pensionsinkomster från ett annat nordiskt land, enligt de generella regler som gäller för alla personer med hemvist i det landet. Sådan beskattning i kombination med rätt till avräkning för den skatt som erlagts i utbetalarlandet är en mycket väl etablerad princip på den internationella beskattningens område. Skatteavtalen syftar till att säkerställa att dubbelbeskattning inte uppstår, men garanterar inte en viss beskattningsnivå på inkomsterna. Den som flyttar till ett annat land och făr tillgång till gemensamt finansierad välfärd i det landet, kan komma att få betala skatt i det landet på sina samtliga inkomster, oavsett var de härrör ifrån. Det kan också innebära en högre beskattning än som var fallet i det tidigare bosättningslandet. Att länderna i Norden har olika nivåer på sin beskattning bör inte ses som ett gränshinder.

Läs mer i Gränshinderdatabasen, granshinder.norden.org, gränshinder nr: 15-005. 


\title{
Skatteavdrag för färöiska studenter i Norge
}

\author{
Färingar som flyttar till Norge för att studera har inte rätt till avdrag \\ för merkostnader vad gäller pendling, hyra eller resor mellan länderna \\ eftersom de kommer från ett land som inte är medlem i EU eller EES.
}

Ett prioriterat hinder av Marjun Magnussen, Färöarna samt Svein Ludvigsen, Norge.

Hindret kan lösas av Finansdepartementet i Norge.

Prioriterat sedan 2015

\section{Bakgrund}

Detta beror på att avdrag för merkostnader bara ges till studenter som reser mellan ett EES-land och ett EU-land och att Färöarna inte är medlem i någon av dessa två.

Det avgörande för rätten till skatteavdrag är, enligt norska och färöiska myndigheter, inte medborgarskap utan det land man färdas till och från.
Även om färingar har danskt medborgarskap när de rör sig utanför Färöarna är landet varken ett EES-land eller ett EU-land. Det betyder att färöiska studenter inte har rätt till skatteavdrag för merkostnader.

Hallå Norden-kontoret på Färöarna har upprepade gånger stött på denna problemställning.

\author{
Vem påverkas \\ Färöiska studenter i Norge. \\ Gränshinderrådets arbete med \\ frågan/kommentarer från berörda \\ regeringar \\ Marjun Magnussen, FO: \\ Just nu arbetas det på att få problem- \\ ställningen belyst och värdera hur stort \\ hindret är innan en möjlig lösningsmo- \\ dell kan tas fram.
}





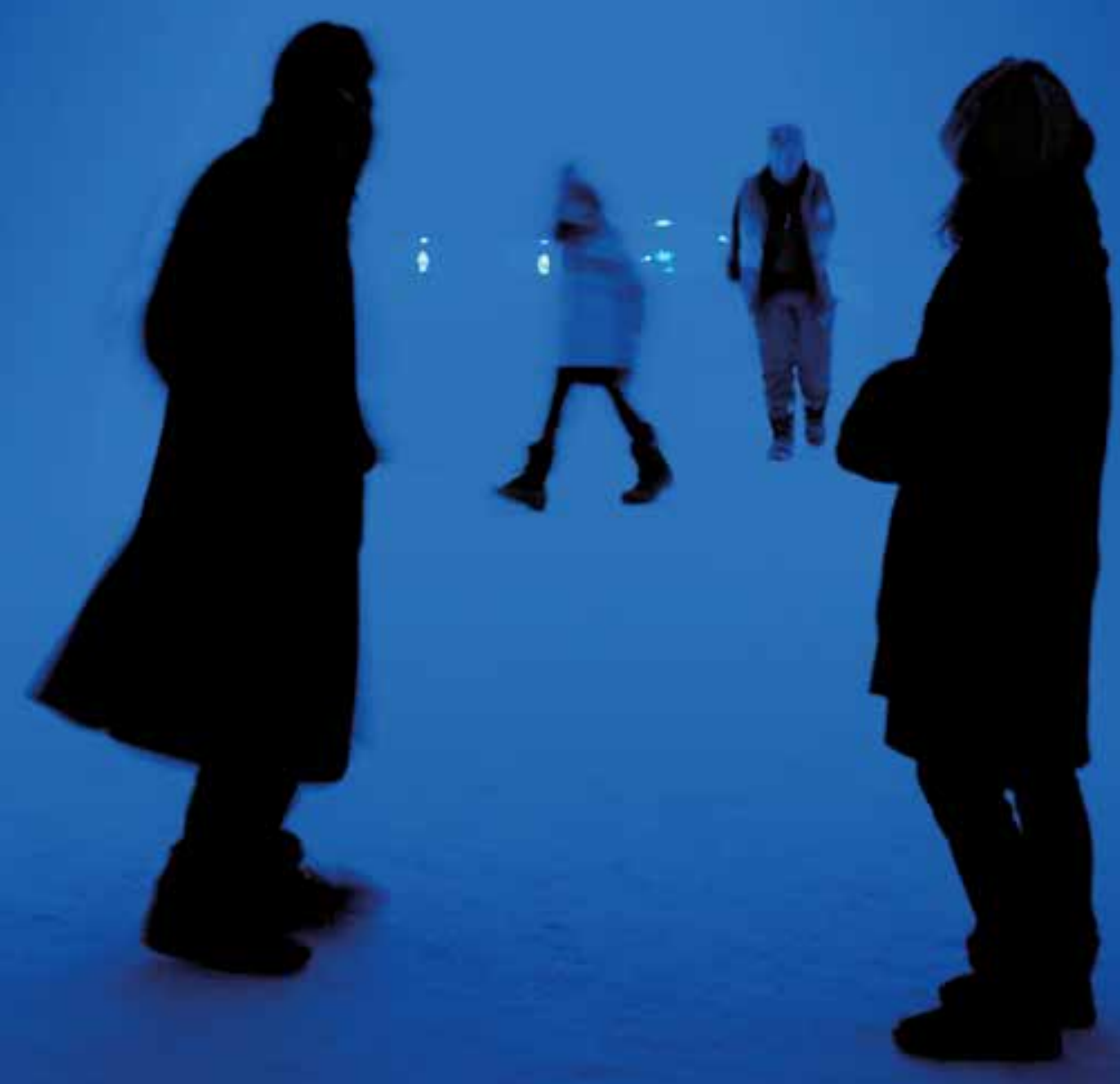




\section{Hinder på näringslivsområdet}




\title{
Erläggande av mervärdeskatt vid överförande av arbetsmaskin från Norge till Sverige
}

\author{
Ett norskt företag som ska införa en arbetsmaskin till Sverige för att där utföra \\ arbete, behövde tidigare betala mervärdesskatt till svenska Tullverket i samband \\ med importen. Denna hantering innebar att den norske företagaren hade en \\ konkurrensnackdel med tillfälligt ökade kostnader i form av betalningen i \\ förhållande till de svenska företagen i samband med arbete i Sverige.
}

Ett prioriterat gränshinder av Annika Hahn-Englund, Sverige samt av MR-Finans.

Hindret är löst av det svenska Finansdepartementet.

Gränshinderrådet arbete med frågan/kommentarer från berörda regeringar

Finansdepartementet, SE:

Riksdagen antog under hösten 2013 en lag som innebär att gränshindret är löst för de företagare som är registrerade till mervärdesskatt i Sverige. Förändringen av hanteringen av mervärdesskatt vid import trädde i kraft den 1 januari 2015.
Förändringen innebär i korthet att företag som är registrerade till mervärdesskatt i Sverige inte längre behöver betala mervärdesskatt till Tullverket vid en import. Denna mervärdesskatt redovisas i stället i företagets skattedeklaration och dras av i samma deklaration, dvs. ingen mervärdesskatt behöver betalas. Det uppkommer därmed inte längre något likviditetsproblem för dessa företag.
Läs mer i Gränshinderdatabasen, www.norden.org gränshinder nr: 14-064. 


\section{Färöiska färdskrivarkort}

\section{Färöiska yrkeschaufförer upplever problem med att få utställt digitala färdskrivarkort på Färöarna (tachografer). Chauffören kan därför inte registrera sin körtid i enlighet med de regler som gäller i Danmark och de övriga nordiska länderna.}

Ett prioriterat gränshinder av Marjun Magnussen, Färöarna.

Hindret kan lösas vid samarbete mellan Danmark och Färöarna.

Prioriterat sedan 2014

\section{Bakgrund}

Det så kallade AETR-avtalet (European Agreement concerning the Work of Crews of Vehicles Engaged in International Road Transport) innehåller regler om internationell yrkestrafik. Enligt avtalet ska yrkeschaufförer registrera sin körtid med en digital färdskrivare.

För parter som inte skrivit under avtalet, bland annat Färöarna, finns dock en möjlighet att fortsättningsvis använda färdskrivarkort som fylls i för hand.

Nya fordon är dock i regel endast utrustade med en digital färdskrivare, vilket innebär att chauffören måste få tillgång till ett digitalt färdskrivarkort. Nuvarande EU-lagstiftning innehåller ett krav på bosättning, medan den förordning som antogs 2014, ger befrielse från detta krav. Denna förordning kommer inte att träda i kraft förrän 2016. Det finns på Färöarna ingen myndighet som kan utställa sådana digitala färdskrivarkort.
Det innebär i sin tur att en färöisk yrkeschaufför stöter på problem då hon/han kommer över till Danmark, eller något av de andra nordiska länderna, eftersom bristen på ett digitalt färdskrivarkort gör att det inte är möjligt att registrera körtiden enligt gällande regler.

\section{Vem påverkas}

Färöiska chaufförer, både de som kör i yrkesmässig trafik som större bussar och transporter samt de som kör akuttransporter/nödhjälp.

\section{Förslag till lösning}

- Färöarna ansluter sig till AETRavtalet, om det är möjligt.

- Möjligheten öppnas för att utfärda digitala färdskrivare.

- Färöarna utser en myndighet som kan utställa digitala färdskrivarkort.

\author{
Gränshinderrådets arbete med \\ frågan/kommentarer från berörda \\ regeringar \\ Marjun Magnussen, FO: \\ Sagen er rejst flere gange overfor \\ danske myndigheder og i nordisk \\ samarbejdsministerregi.
}

Med ikrafttrædelsen af tachograforordningen 2. marts 2016 bliver det muligt for danske myndigheder at udstede førerkort til færøske chauffører bosat på Færøerne. Det vurderes, at det i denne sammenhæng er nødvendigt med en mindre ændring af bekendtgørelsen om udstedelse af fartskriverkort. Det forventes derfor, at sagen løses i løbet af 2016.

Läs mer i gränshinderdatabasen, granshinder.norden.org, gränshinder nr: 14-152. 


\title{
Norska tull- och momsregler för nordiska företag
}

\author{
Ett nordiskt företag som ska införa en arbetsmaskin till Norge för att utföra arbete \\ där ska idag deponera mervärdesskatt till Norge. Det betyder att den nordiska \\ företagaren har en konkurrensnackdel med tillfälligt ökade kostnader i form av \\ depositionen i förhållande till de norska företagen samband med arbete i Norge.
}

Ett prioriterat gränshinder av Svein Ludvigsen, Norge samt av MR-Finans.

Hindret kan lösas av det norska Finansdepartementet.

Prioriterat sedan 2014

\section{Bakgrund}

Både EU och Norge är bundna av en internationell konvention som reglerar möjligheterna till tull/momsfrihet (Istanbulkonventionen). Bestämmelserna är sålunda mycket svåra att ändra på. Det betyder att den som för en anläggningsmaskin, exempelvis en grävmaskin, mellan Norge och EU ska betala mervärdesskatt för varan till Norge eller EU.

Kraven på betalning av mervärdesskatt vid införsel kan innebära likviditetsproblem för exempelvis små byggföretag som vill ta uppdrag på andra sidan gränsen.

\section{Vem påverkas}

Detta hinder påverkar företag från Danmark, Finland, Grönland, Färöarna, Norge, Sverige, Island och Åland som ska utföra entreprenadarbeten i Norge.

\section{Förslag till lösning}

En lösning som har diskuterats är att anpassa när och hur moms ska betalas (reverse charge), så att företagens likviditetsproblem minimeras. För att en sådan lösning ska kunna utvecklas krävs troligen politiska signaler till myndigheterna. En annan möjlighet är att följa den svenska modellen.

\section{Ekonomiska konsekvenser}

Ett svenskt småföretag med en arbetsmaskin till ett värde av 2,5 miljoner SEK förväntas få en kostnad på 530000 SEK i samband med ett tremånadersarbete $\mathbf{i}$ Norge. Det är tre olika typer av kostnader som företaget har: räntekostnader till lån för att finansiera momsinbetalningen, avskrivning av arbetsmaskinens värde under arbetet i Norge samt en avgift på $5 \%$ av arbetsmaskinens värde för varje månad arbetsmaskinen uppehåller sig i Norge.
Den norska staten får en intäkt på 516000 SEK om det svenska företaget väljer att utföra uppdraget i Norge. Närmare beräkningar finns nedan.

\section{Gränshinderrådets arbete med frågan/kommentarer från berörda regeringar \\ Svein Ludvigsen, NO:}

Finansdepartementet har i prop. 1 LS (2015-2016) fremmet lovforslag (for Stortinget) om overføring av forvaltningen av merverdiavgift ved innførsel fra Tolletaten til Skatteetaten. Forslaget innebærer at merverdiavgift ved innførsel for avgiftspliktige som er eller skal være registrert i Merverdiavgiftsregistret skal oppgis i den ordinære (innenlandske) omsetningsoppgaven. Registrerte avgiftspliktige som har fradragsrett for inngående merverdiavgift, herunder innførselsmerverdiavgift, skal i tilfelle ikke lenger betale merverdi- 


\section{Beräkningar}

För en småföretagare med en omsättning på 2 miljoner SEK motsvarar en deposition en tredjedel av företagets årliga omsättning. Ett likviditetsbehov som småföretagaren inte kan uppfylla utan att ta lån. Vilket innebär att småföretagaren måste uppta ett lån med säkerhet i grävmaskinen till en ränta på 6 \%.

Arbetsmaskinens värde, Caterpillar 320DFMHW (årsmodell 2013)

2500000 SEK

Likviditetsbehov

650000 SEK

Utgifter för företagaren

Räntekostnader vid lån till 6 procents ränta i ett halvt år

18800 SEK

Avgift (5 \% av maskinens värde per månad i 3 månader)

375000 SEK

Avskrivning av maskinens värde under perioden i Norge

136000 SEK

\section{Utgifter totalt}

529800 SEK

Intäkter för den norska staten

Ränteintäkter av en sex månaders deposition

Avgift (5 \% av maskinens värde per månad i tre månader)

4700 SEK

Avskrivning av maskinens värde under perioden i Norge

Pris på Caterpillar 320DFMHW (årsmodell 2013) hämtat på www.marcus.se

avgift til Tolletaten. Den gjeldende ordning med at merverdiavgift ved innførsel først skal innbetales til Tolletaten og senere fradragsføres som inngående avgift i den ordinære omsetningsoppgaven vil dermed bli avviklet. Den nye ordningen er foreslått satt $\mathrm{i}$ kraft fra

1. januar 2017.

Läs mer i Gränshinderdatabasen, granshinder.norden.org, gränshinder nr: 14-064. 


\section{Olika byggbestämmelser}

\section{De nordiska ländernas krav på byggmaterial skiljer sig åt, vilket försvårar entreprenörernas verksamhet och hämmar handeln över gränser}

Ett gränshinder som prioriteras av Sten Palmgren, Finland, och Gunnar Westerholm, Åland. Även prioriterat av MR-NER.

Gränshindret ingår i avtalet mellan det danska Folketinget och regeringen.

Hela Norden berörs av detta hinder.

Prioriterat sedan 2014

\section{Bakgrund}

Olika byggbestämmelser gör det svårt för företag som är verksamma i ett land att röra sig över gränserna. Det har en negativ effekt på konkurrensen och gör det svårt att utveckla den nordiska gemensamma hemmamarknaden. Gränshindret är i sig mycket brett och består av en rad problemställningar som rör bland annat VVS-området, elinstallationer, brand- och bullerskydd samt klassificering och certifiering av dessa.

En bidragande faktor är att många av byggbestämmelserna sätts av ländernas branschorganisationer, något som gör det svårt att angripa problemet genom lagstiftning. I den mån det finns offentlig reglering finns det $i$ sin tur skillnader i de nivåer som bestämmelserna sätts på. I Sverige finns regleringen till exempel på lag-, förordningsoch myndighetsnivå. I Finland kan byggbestämmelserna variera mellan olika kommuner. Därutöver finns olika rekommendationer, råd och frivilliga standarder med olika juridisk status beroende på vilket land det är fråga om. Rent konkret kan det röra sig om skillnader i kraven gällande exempelvis tröskelhöjder, bullerskyddsnivåer och virkesdimensioner.

Skillnaderna mellan länderna gör det förståeligt att det är svårt för mindre företag och småhusleverantörer att anpassa sin produktion till alla de olika kraven och standarderna. En del av problemen löses visserligen på europeisk nivå, men det finns stor potential för de nordiska länderna att fungera som föregångare och skapa gemensamma bestämmelser. Det gäller i synnerhet utarbetandet av helt nya byggregler. En större grad av harmonisering skulle skapa en större marknad för alla entreprenörer i Norden och på sikt bidra till en lägre prisnivå för konsumenterna.

\section{Förslag till lösning}

Ett visst problemområde, exempelvis brand- och bullerskydd, görs till pilotprojekt för att utarbeta gemensamma nordiska byggbestämmelser. Erfarenheterna kan sedan användas för att harmonisera andra bestämmelser.

\section{Gränshinderrådets arbete med frågan/ kommentarer från berör- da regeringar Sten Palmgren, Fl: \\ Diskussioner har förts i Finland med Miljöministeriet. \\ För att gå vidare med frågan borde fo- kus läggas på ett eller två konkreta hin- der. Buller och brand är två pilotprojekt där det redan gjorts en del förarbete. Gränshinderrådets sekretariat utreder möjligheterna att ordna rundabords- samtal med relevanta parter.}




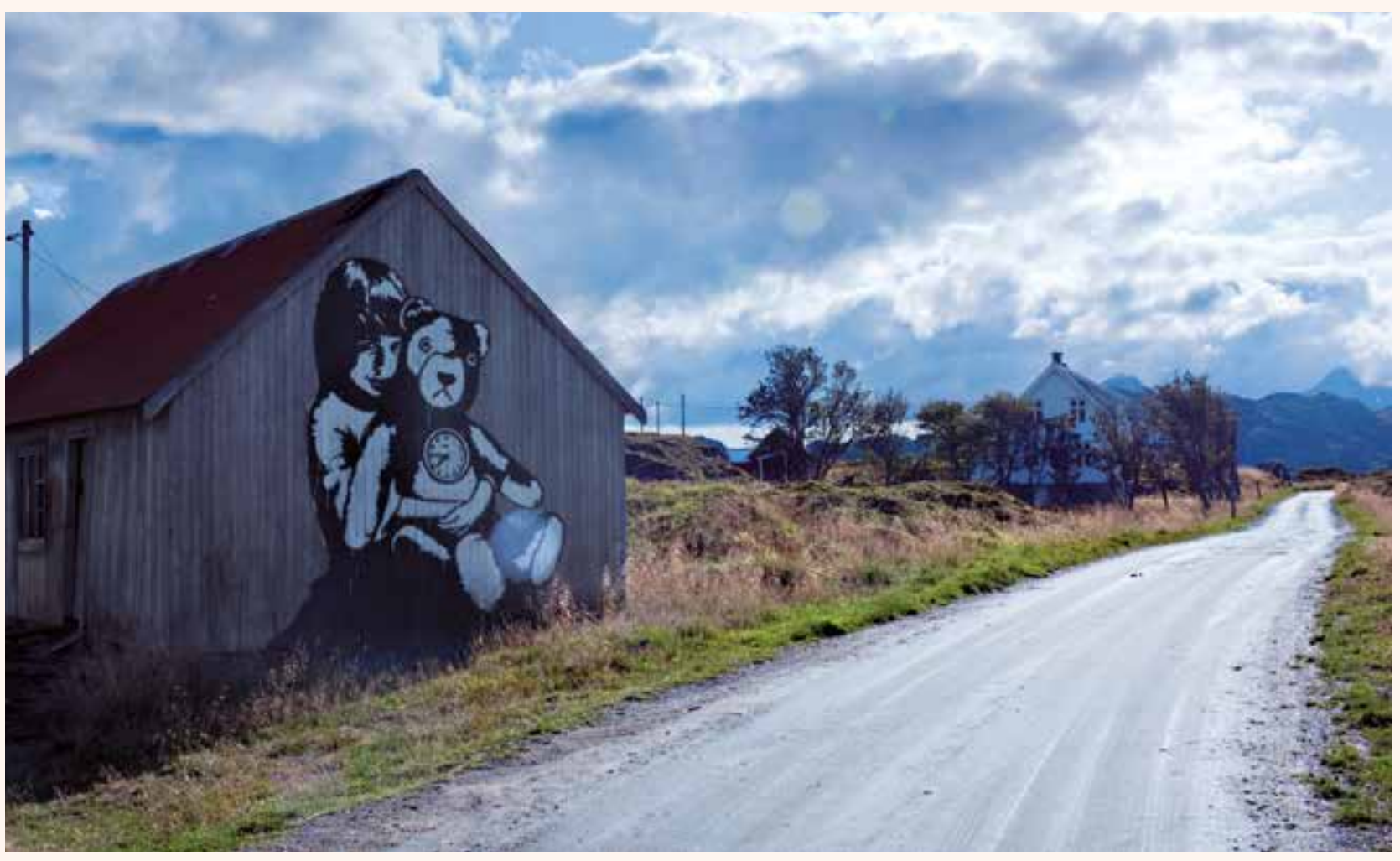

\section{Miljöministeriet, FI:}

Fortsatta diskussioner har förts med miljöministeriet i Finland som betonar att man inte bör närma sig problematiken som en standardiseringsfråga utan som en fråga om byggnadstillsyn och nationella byggbestämmelser. En förenkling av byggbestämmelserna är aktuell i många länder. Det har varit svårt att avsätta resurser för nordiskt samarbete, även om det skulle finnas ett behov av det. Samarbete bör bedrivas inom Nordiska byggmyndigheternas möten, där man ska följa upp normgivningen, tillnärma varandras normer och samarbeta i EU-frågor. De tjänstemän som kan påverka bör delta i Nordiska byggmyndigheternas möten.

Arbetet bör fortsätta genom att ordna ett nordiskt seminarium för att bedöma om det nordiska samarbetet kan återupptas i likhet med nordiska kommittén för byggbestämmelser (NKB) och hur man i övrigt kan utveckla samarbetet med hänsyn till de begränsade resurserna. Samarbetsformer och processer för att förmedla information om byggregler med målet att tillnärma bestämmelserna varandra samt beakta åtgärder på EU-nivå för byggprodukternas inre marknad bör också diskuteras. Därutöver bör man utveckla informationsförmedlingen i anslutning till EU:s lagstiftningsarbete och dess genomförande och utifrån gemensamma ståndpunkter förbereda förslag till harmonisering av byggregler som skapar gränshinder, där olika nationella kulturer för boende och byggande beaktas.

Läs mer i gränshinderdatabasen, granshinder.norden.org, gränshinder nr:14-076. 


\section{Eltariffer för Åland}

\section{Åland importerar större delen av sin elektricitet från Sverige via kabel som ägs av Kraftnät Åland AB. Kabeln är ansluten till det svenska regionnätet som i detta fall ägs av Vattenfall regionnät $A B$, vilket innebär att Åland måste betala regionnätsavgifter till Vattenfall.}

Ett prioriterat gränshinder av Gunnar Westerholm, Åland, Sten Palmgren, Finland. Även prioriterat av MR-NER.

Hindret kan lösas av Ålands landskapsregering, Sveriges regering (näringsdepartementet),

Finlands regering (arbets- och näringsministeriet), Kraftnät Åland, Svenska kraftnät och Vattenfall AB.

Prioriterat sedan 2014

\section{Bakgrund}

Då Åland har egen lagstiftningsbehörighet över energifrågor ska Kraftnät Åland jämställas med det svenska stamnätsbolaget Svenska Kraftnät. Kraftnät Åland är en eget TSO, Transmission System Operator, sedan hösten 2015. Enligt EU-direktivet 2009/72 och förordning 714/2009 fastställs att avgifter mellan TSO inte ska förekomma. Kraftnät Åland betalade år 2014 över 1 miljon EUR till Vattenfall i regionnätsavgifter. En kostnad som i sista hand påförs åländska företag och konsumenter.

\section{Vem påverkas}

Ålands 22000 abonnenter är starkast berörda. Vid årsskiftet 2015/2016 är en kabel mellan Åland och finska fastlandet klar för att tas i bruk. Det ger möjlighet till transitering mellan Finland och
Sverige av bland annat grön el, vilket kommer förbrukare i Sverige, Åland och Finland till del.

\section{Ekonomiska konsekvenser}

År 2014 var den totala elförbrukningen på Åland $288 \mathrm{GWh}$. Ålands Kraftnät AB importerade ca. $70 \%$, motsvarande till 201 GWh, från Vattenfall Eldistribution $A B$ i Sverige. Kraftnät Åland betalade år 2014 ca. 1,1 miljon EUR till Vattenfall i regionnätsavgifter. När gränshindret blir löst bortfaller dessa nätavgifter, vilket medför en besparing på ca. 49 EUR/år för en genomsnittlig abonnent med en förbrukning på 13100 KWh/år. Se närmare beräkningar nedan. Dessutom möjliggörs transitering av el mellan Finland och Sverige vilket bidrar till en prisreduktion.

\section{Förslag till lösning}

Att Sveriges regering erkänner Kraftnät Ålands status som TSO och att förbindelsen klassificeras som en utlandsförbindelse och avgiften för förbindelsen mellan Åland-Sverige därmed avskaffas.

\section{Gränshinderrådets arbete med frågan}

Gränshinderrådet informeras löpande om de diskussioner som hålls mellan Sverige, Finland och Åland.

\section{Kommentarer från berörda regeringar \\ Ålands landskapsregering}

Då Åland har egen lagstiftningsbehörighet över energifrågor skall Kraftnät Åland jämställas med det svenska stamnätsbolaget Svenska Kraftnät. Landskapsregeringen på Åland konstaterar att frågan är komplex och att 


\section{Beräkningar}

\begin{tabular}{|c|c|c|}
\hline Elförbrukning 2014 & $288 \mathrm{GWh}$ & $288000000 \mathrm{KWh}$ \\
\hline Import från Vattenfall Eldistribution $\mathrm{AB}$ (Sverige) & $200,695 \mathrm{GWh}$ & $200695000 \mathrm{KWh}$ \\
\hline Kostnad för nätavgift till Vattenfall Eldistribution $A B$ & 1069000 EUR & 1069000 EUR \\
\hline Nätavgift & $3711,806 \mathrm{EUR} / \mathrm{GWh}$ & $0,003711806 \mathrm{EUR} / \mathrm{KWh}$ \\
\hline Genomsnittlig förbrukning hos åländska elförbrukare & & $13,100 \mathrm{KWh} / a ̊ r$ \\
\hline Om nätavgiften bortfaller sparar den genomsnittlige förbrukaren & & 48,59 EUR/år \\
\hline
\end{tabular}

samsyn inte råder. Ålands infrastrukturminister Veronica Thörnroos hade i september 2015 ett möte med Sveriges energiminister Ibrahim Baylan för att diskutera möjligheterna till el-transitering mellan Finland och Sverige som den nya kabelförbindelsen medför. Detta är i linje med EUs ambition att underlätta energitransitering mellan nationerna. En förutsättning för att nyttja förbindelsens fulla potential är att förbindelsen klassificeras som en utlandsförbindelse.

\section{Sten Palmgren FI}

På den gemensamma elmarknaden ska alla gränsförbindelser i enlighet EUbestämmelserna användas till gagn för marknaden. Tariffen på svenska sidan är ett hinder för effektivt utnyttjande av förbindelsen mellan finländska fastlandet och Sverige. Från finländsk sida har man ett stort intresse av att kunna nyttja den fria kapaciteten i förbindelsen Sverige-Finland för transitering, vilket förutsätter att denna fråga blir löst.

\begin{abstract}
Kommentar från Sveriges regering Omständigheterna att Kraftnät Åland AB är certifierade som TSO och att Åland snart får en överföringsförbindelse med det finska fastlandet ändrar inte de juridiska ställningstagenden som Sverige gjort om att Ålandskabeln är en regionnätskabel som inte faller in under EU-förordningen 714/2009 bestämmelser om avgiftsfrihet för gränsöverskridande stamnätskablar.
\end{abstract}

Läs mer i Gränshinderdatabasen, granshinder.norden.org, gränshinder nr: 14-162. 
Övriga gränshinder

.

(1) 


\title{
Samordningsnummer till utländska fritidshusägare i Sverige
}

\author{
Utländska fritidshusägare i Sverige upplever problem med att \\ teckna el-, tele- och internetavtal på grund av att de varken har \\ personnummer eller samordningsnummer.
}

Ett prioriterat gränshinder av Annika Hahn-Englund, Sverige.

Hindret kan lösas av det svenska Finansdepartementet (dock ej helt då samordningsnummer inte ersätter personnummer i alla avseenden).

\section{Prioriterat sedan 2014}

\section{Bakgrund}

Även om problemet rör en begränsad grupp av människor så visar detta ändå tydligt vilka konsekvenser avsaknaden av ett personnummer har. Det gäller i synnerhet i Sverige där systemen för service, tjänster och handel är uppbyggt på personnummer. För betalning av fastighetsavgift m.m. får utländska fritidshusägare ett så kallat GD-nummer som de använder i kontakt med Skatteverket. Detta nummer har ingen spridning i samhället i övrigt.

Numret fyller i stort sett ingen funktion i kontakt med privata aktörer, vilket leder till problem vid tecknandet av exempelvis el-, tele- och internetavtal. Utländska fritidshusägare har därför behov av att få ett så kallat samordningsnummer, som får spridning i samhället genom Statens personadressregister, SPAR.

\section{Vem påverkas}

Utländska fritidshusägare i Sverige, totalt cirka 36500 personer varav ungefär 22500 kommer från Danmark, Norge eller Finland. Av dessa har $78 \%$, omkring 28700 personer, uppgett att de har behov av ett samordningsnummer.

\section{Ekonomiska konsekvenser}

Enligt en utredning gjord av svenska Skatteverket kostar det 19 miljoner SEK, en engångsinvestering, att införa ett system där Lantmäteriet ges möjlighet att tilldela utländska fastighetsägare ett samordningsnummer. Det årliga sparandet enligt samma utredning värderas till 870000 SEK vilket betyder att denna investering kommer att vara intjänad inom 25-28 år.

Om hälften av de utländska fritidshusägarna som uppgett att de har behov av ett samordningsnummer skulle teckna ett TV-abonnemang till 269 SEK/månad, skulle de bidra öka omsättningen för TV-abonnemang med ungefär 46 miljoner SEK. Närmare beräkningar finns nedan.

\section{Förslag till lösning}

Samordningsnummer ska även tilldelas utländska fritidshusägare.

\section{Gränshinderrådets arbete med frågan/kommentarer från berörda regeringar}

Finansdepartementet, SE:

Finansdepartementet har inlett en dialog med Skatteverket och Lantmäteriet om hur frågan om samordningsnummer till utländska fastighetsägare kan lösas.

Läs mer i Gränshinderdatabasen, granshinder.norden.org, gränshinder nr: 14-160. 


\section{Beräkningar}

Antal utländska fritidshusägare i Sverigre

36761 personer

Norrmän

11605 personer

Finländare

235 personer

Danskar

11605 personer

Övriga

13316 personer

Andel som är i behov av samordningsnummer $=78 \%$

28674 personer

Hälften av dessa tecknar ett TV-avtal (beräknat för Boxer Mix)

14337 personer

Kostnad för TV-avtal/månad

269 SEK

Total årlig utgift för utländska fritidshusägare, enbart för TV-avtal

46279158 SEK

Kostnad för att införa samordningsnummer

19000000 SEK 


\section{Gränsregional statistik}

Flera tusen nordiska medborgare pendlar till grannländerna på grund av arbete, studier eller andra orsaker. För att få en överblick över storleken och utseendet på pendlingen och andra flöden över gränserna är det viktigt att etablera en långsiktig finansiering av gränsregional statistik.

Statistik är ett viktigt underlag för beslutsfattare för att ta beslut som gagnar de som rör sig över de nordiska gränserna. Denna statistik är särskilt viktig för Gränshinderrådets arbete.

Ett prioriterat gränshinder av Sten Palmgren, Finland. Även prioriterat av MR-SAM.

Prioriterat sedan 2015

Under det finska ordförandeskapet 2016 är gränsregional statistik ett prioriterat område och man kommer till att starta upp ett treårigt projekt kring gränsregionalstatistik i Norden. Därefter kommer projektet att drivas vidare av Nordiska ministerrådet. 


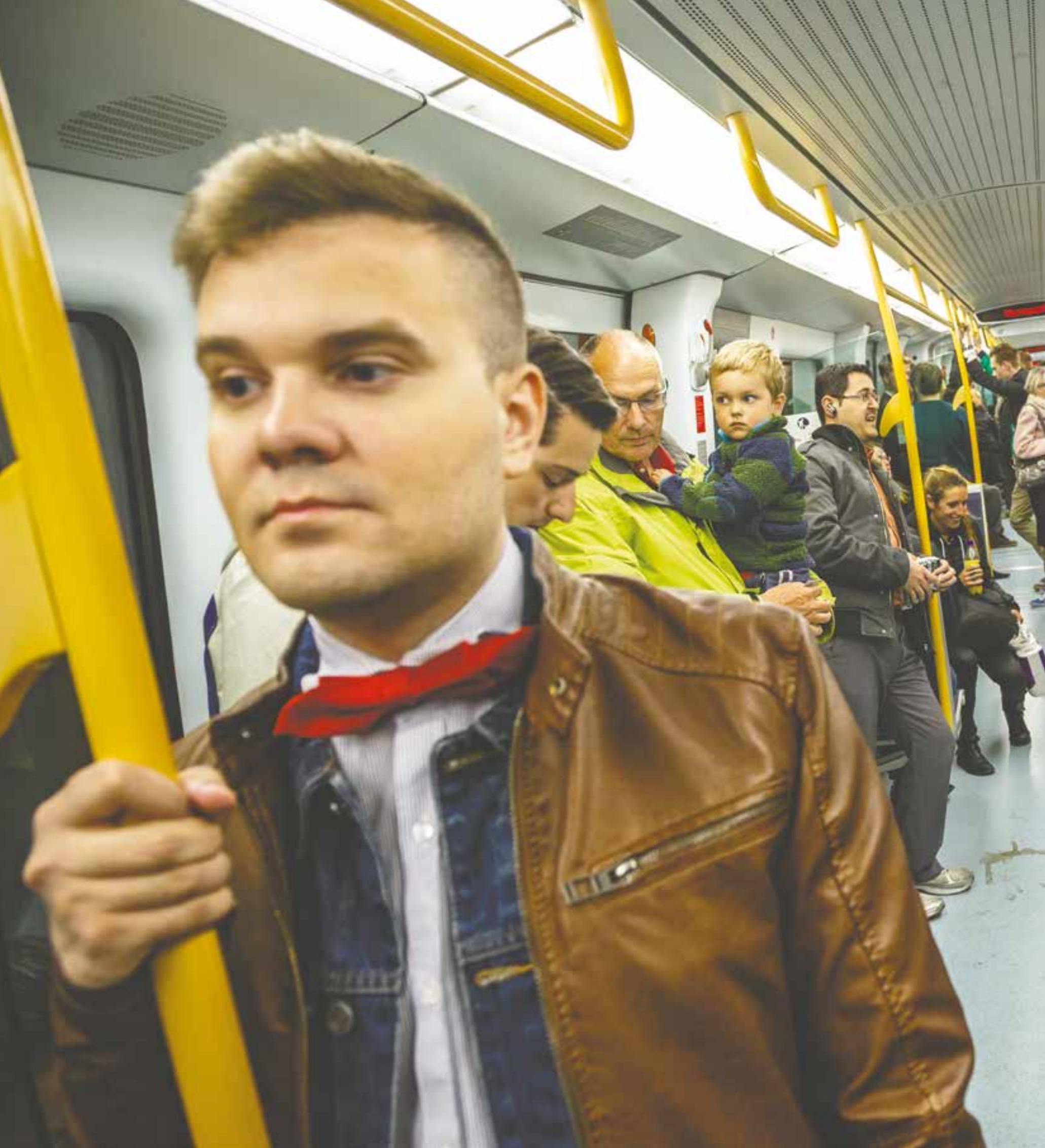




\title{
Erkännande av färöiska körkort
}

\author{
Färöiska körkort kan inte bytas ut i alla de nordiska länder då en \\ person flyttar till ett annat nordiskt land.
}

Ett prioriterat gränshinder av Marjun Magnussen, Färöarna.

\section{Prioriterat sedan 2014}

\section{Bakgrund}

När en person bosätter sig i ett nordiskt land ska gällande körkort bytas ut till bosättningslandets. Färöiska körkort kan inte bytas ut i alla nordiska länder. I Sverige och i Finland betraktas det färöiska körkortet som utgivet i ett land som inte är medlem av EU och kan därför inte bytas ut mot det svenska eller det finska.

Färöarna omfattas inte av överenskommelsen gjord den 12 november 1985 mellan Danmark, Finland, Sverige och Norge om gemensamt godkännande av körkort och registrering av fordon och det är inte möjligt att ansluta till överenskommelsen vid nuvarande tidpunkt. Det har funnits överväganden om att göra en revision av överenskommelsen i nordisk regi, men detta har lämnats utan åtgärd, då de områden som överenskommelsen omfattar, till stor del regleras av EU-regler, inklusive $E U: s$ körkortsregler. Färöarna är varken medlem av EU eller EES.
Det är möjligt att byta ut det färöiska körkortet mot ett danskt, norskt, isländskt och brittiskt. Detta kan innebära att innehavaren av ett färöiskt körkort tvingas mellanemigrera till ett av dessa länder för att kunna byta ut sina körkort vid bosättning i Sverige eller Finland.

Det finns inga trafiksäkerhetsmässiga aspekter att beakta vid utbyte av körkort. Färöarna har till stor del implementerat körkortsdirektivet i färöisk lagstiftning. Under hösten har den färöiska lagen som berör körkort, åter uppdaterats i förhållande till körkortsdirektivet och den förväntas således inom kort att tas i användning.

Under hösten har den färöiska lagen gällande körkort åter uppdaterats $\mathrm{i}$ relation till körkortsdirektivet. Inom kort förväntas ett färöiskt körkort att bli identiskt med andra körkort inom EU/EES och uppfylla alla EU/EES-krav/ regler.

\section{Förslag till lösning}

De länder som idag inte har behörighet att ersätta det färöiska körkortet skulle kunna se över gällande regler för en bedömning av möjligheten att byta körkort på samma villkor som för medborgare $i$ övriga Norden och i EU/EES-länderna.

\section{Vem påverkas}

Personer med färöiska körkort kommer att påverkas. Det är svårt att säga hur många, då det antas att en del av dessa i dag väljer att mellanemigrera. Oavsett hur många personer det rör sig om är det viktigt för enskilda personer som drabbas. De flesta personer bör kunna byta ut det färöiska körkortet mot ett nytt som uppfyller EU:s krav/regler, precis som med tidigare färöiska pass, vilka kunde bytas ut mot EU-pass. 
Gränshinderrådets arbete med frågan/kommentarer från berörda regeringar

\section{Marjun Magnussen, FO:}

Frågan om erkännande av färöiska körkort har dryftats i många år och det verkar svårt att se en slutgiltig lösning av frågan. Nu senast har Gränshinderssekretariatet hört sig för om en möjlig revision av överenskommelsen från den 12 december 1985 rörande ömsesidigt erkännande av körkort. Detta initiativ välkomnas från färöisk sida.

På grund av val och ny regeringsbildning under hösten 2015 har det inte varit möjligt att hinna behandla saken innan tidsfristens utgång.

Läs mer i gränshinderdatabasen, granshinder.norden.org, gränshinder nr: 14-128.

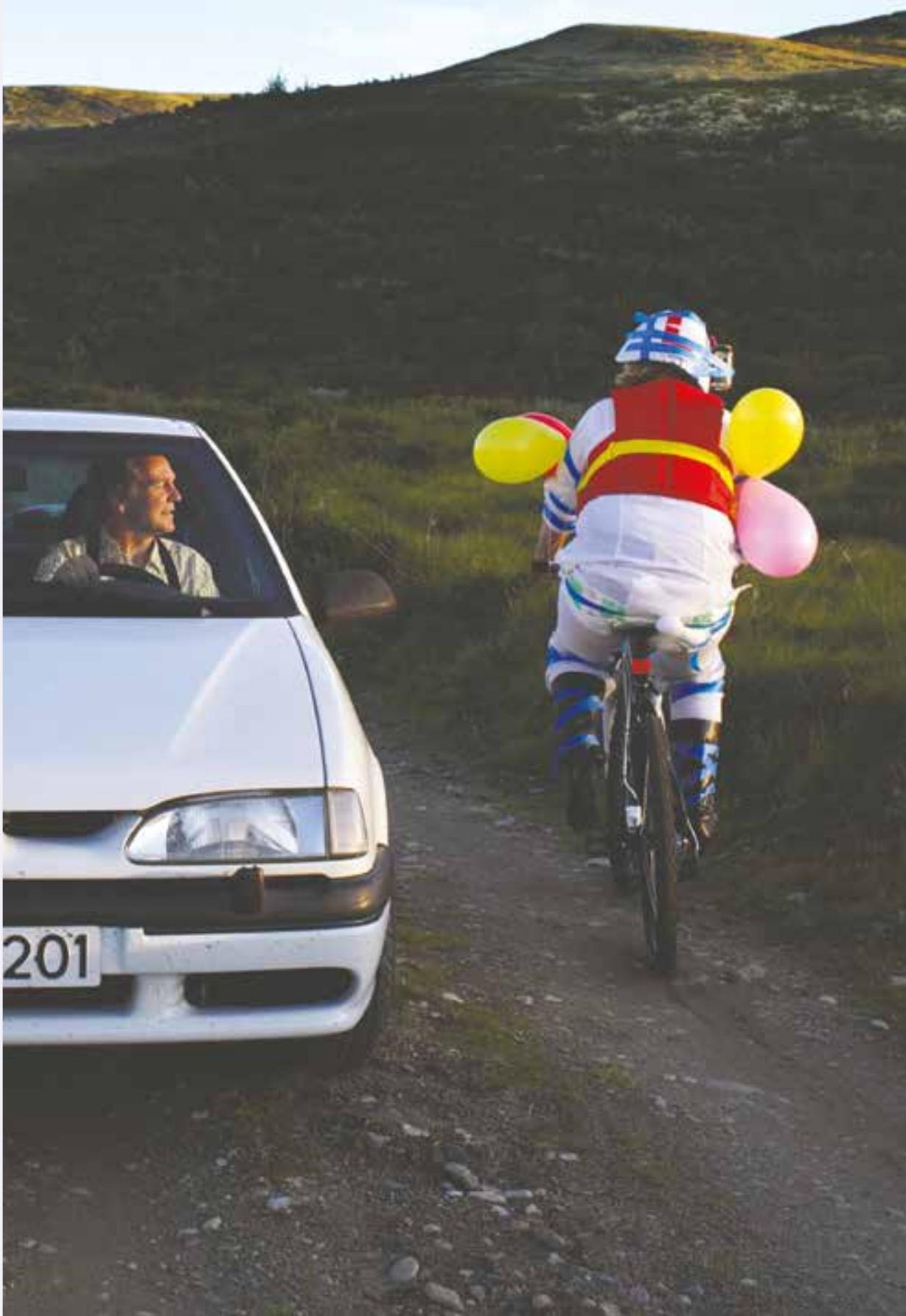




\section{Grönländska körkort}

Ett prioriterat gränshinder av Christian Wennecke, Grönland.

Hindret kan lösas av Rigspolitiet.

Prioriterat sedan 2014

\section{Bakgrund}

Den som reser till Danmark med sitt grönländska körkort, kan använda det i 90 dagar, därefter måste personen göra ett körprov. Detta körprov kan anses vara irrelevant om personen redan har kört i 90 dagar.

Olika regler gäller för körkort från respektive Färöarna och Grönland $\mathrm{i}$ de nordiska länderna. De regler som gäller för Grönland är ofta strängare än de regler som gäller för Färöarna. Du kan använda det färöiska körkortet $\mathrm{i}$ Danmark utan att behöva byta ut kortet, eller betala för körprov.

\section{Vem påverkas?}

Ett svar förväntades från Rigspolitiet om hur många grönländska körkort som bytts ut det senaste året, samt hur stor misslyckandeprocenten är för körprovet i detta sammanhang. Rigspolititet har meddelat att man inte för någon statistik.

\section{Ekonomiska konsekvenser}

Den som berörs av detta hinder har följande utgifter:

- 280 DKK för utbyte av körkort.
- 890 DKK för körprov.

- Hyra av godkänt fordon till körprovet.

- Eventuella extra körtimmar.

\section{Förslag till lösning}

a) Ändring av den danska körkortsförordningen så att samma villkor gäller för grönländska körkort som nu gäller för färöiska.

b) Revision av överenskommelse från den 12 december 1985 som gäller ömsesidigt erkännande av körkort etc.

c) Andra länder som särskilt nämner Grönland i sin lagstiftning (exempelvis Norge), kan behöva ändra sin lagstiftning.

\section{Gränshinderrådets arbete med frågan/kommentarer från berörda regeringar}

Departementet for Bolig, Byggeri og Infrastruktur, GL:

Departementet for Bolig, Byggeri og Infrastruktur kan oplyse, at landtransportområdet ikke er hjemtaget og at det er Danmark, som har myndighed på området. Det er derfor danske regler, der er gældende for udstedelser af kørekort i Grønland. I Grønland er det
Grønlands Politi, som har kompetencen til at udstede grønlandske kørekort.

Departementet for Bolig, Byggeri og Infrastruktur vil redegøre for, at kørekort er et rigsanliggende og man skal henvise til danske myndigheder og Justitsministeriet, idet der ikke er tale om et teknisk grønlandsk anliggende, men et statsligt anliggende.

Hvis det grønlandske kørekort skal sidestilles med det danske kørekort, så vil man være i stand til at ansøge om internationalt kørekort. Men et internationalt kørekort er en formaliseret og internationalt anerkendt oversættelse af et kørekort, som er gyldig i over 175 lande og kan være nødvendig, hvis man skal køre i andre lande end EU-lande og EØS-lande.

I Grønland kan man få udstedt et internationalt kørekort, hvis man har et gyldigt dansk kørekort.

Läs mer i gränshinderdatabasen, granshinder.norden.org, gränshinder nr. 14-172. 


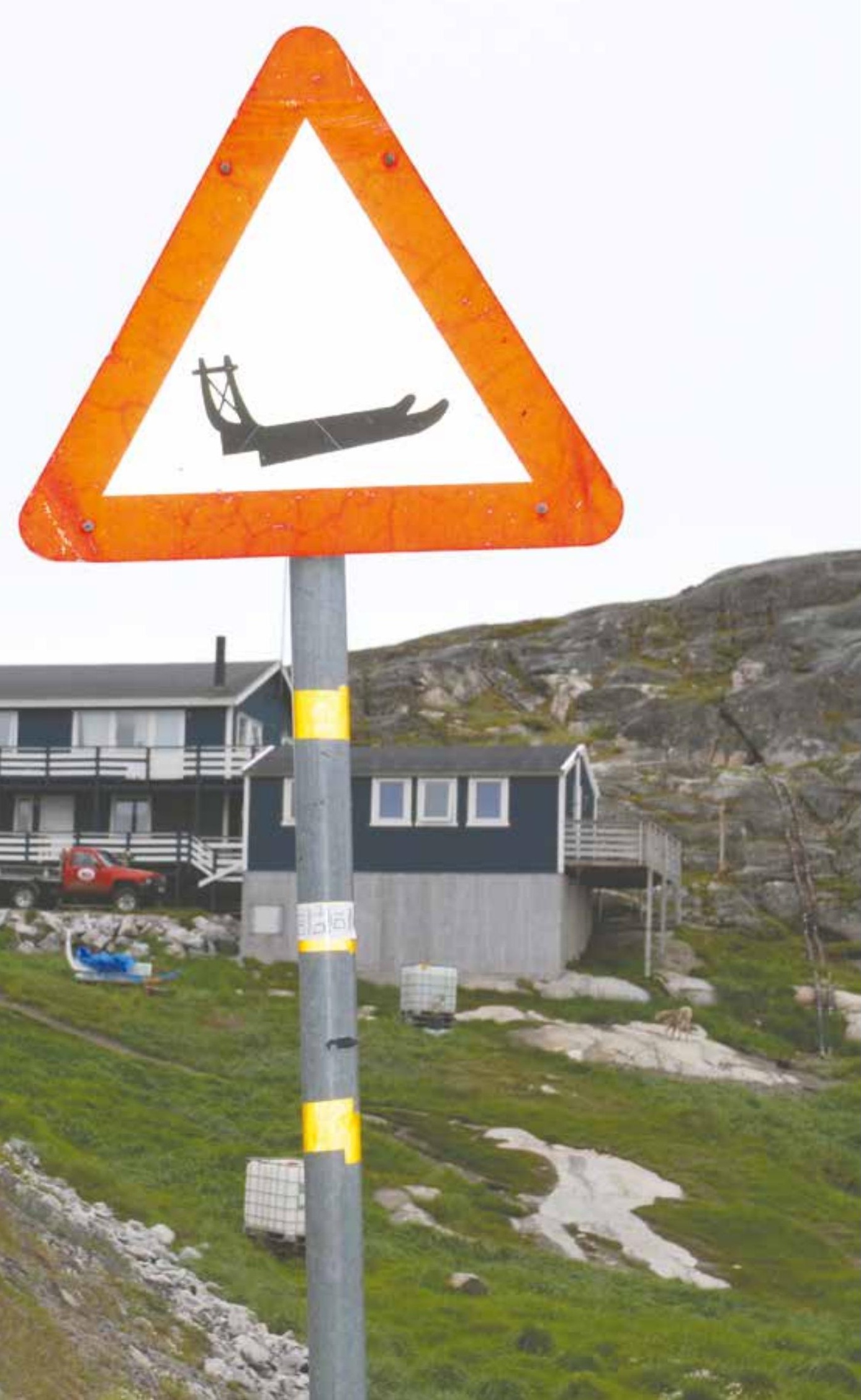




\title{
Akuta gränshinder
}

\author{
Utöver prioriterade gränshinder driver Gränshinderrådet även de \\ gränshinder som uppkommer och identifieras som akuta, och som \\ är av särskilt stort intresse att få lösta under året. Denna typ av \\ gränshinder uppkommer oftast genom ändringar i regelverken.
}

Löst

\section{Arjeplogavtalet}

\section{Bakgrund}

Arjeplogavtalet, eller "Överenskommelse om gemensam nordisk arbetsmarknad för viss hälso- och sjukvårdspersonal och veterinärer", ingicks 1993 och trädde i kraft den 1 januari 1994. Överenskommelsens syfte är att ge nordiska medborgare inom de av avtalet berörda 22 yrkesgrupperna tillgång till hela den nordiska arbetsmarknaden. Exempelvis ska en person som har en godkänd fysioterapeututbildning i Finland också få sin utbildning godkänd och kunna arbeta som fysioterapeut i Sverige.

\section{Lösning}

Nordiska rådet har gett klartecken för det reviderade Arjeplogavtalet vilket innebär att patientsäkerheten ökar och att felbehandlande läkare inte längre kan röra sig mellan länderna.

Ministerrådet för social- och hälsopolitik (MR-S) har sedan en tid övervägt möjligheterna till att upphäva alternativt ändra Arjeplogavtalet. Förändringen innebär att reglerna i EU:s yrkeskvalifikationsdirektiv nu blir gällande i hela Norden. En tätare nordisk informationsutväxling kommer nu att kunna ske genom EU:s alarmsystem IMI vilket främjar patientsäkerheten.

Alarmsystemet ska utvärderas efter två år, enligt Nordiska rådet. Finner man att det inte ger ett tillräckligt bra skydd för patientsäkerheten, så bör länderna överväga ett eget nordiskt elektroniskt register.

De nordiska social- och hälsoministrarna kommer att underteckna det ändrade avtalet under våren 2016. 


\section{Finskt krav på säkerhet vid tillfällig import av husvagnar, skotrar, etc.}

\section{Bakgrund}

Den som tar med sig ett fordon lastat på exempelvis en släpvagn ska ställa en säkerhet på 24-34 \% av värdet vid införandet till Finland. Denna praxis innefattar: snöskotrar, ATV (fyrhjulingar), vattenskotrar, motorbåtar, motorcyklar lastade på ett släpfordon samt husvagnar. Denna summa återbetalas sedan efter returen till Norge, men detta tar oftast ett tag. Finland började med detta förfarande i juli 2015 när instruktionerna från finska tullen skärptes baserat på en EU-regel. Sverige har aviserat att man inte kommer att skärpa instruktionerna i dagsläget.

\author{
Vem påverkas? \\ Detta förfarande får stora konsekvenser \\ för näringsliv på bägge sidor, särskilt \\ eftersom norsk vintercamping i norra \\ Finland är väldigt populärt. I gränsområ- \\ det Kilpisjärvi finns det cirka 500 norska \\ husvagnar under vintersäsongen. Till \\ det tillkommer norska stuggäster som \\ tar med sig sina snöskotrar under helg- \\ vistelser. I Storfjord kommun finns cirka \\ 2000 stugor och platser för husvagnar, \\ där många har etablerat på norska \\ sidan för att kunna ta dagsturer med \\ snöskotern till Finland.
}

\section{Ekonomiska konsekvenser}

Denna nya praxis träffar särskilt norska familjer som har sin husvagn fast på finsk sida under vintern och uppehåller sig där på helgerna. Exempelvis måste en norsk familj med en nordamerikanskt producerad snöskoter betala $10 \%$ importavgift och $24 \%$ moms, totalt $34 \%$ av inköpspriset. Om inköpspriset ligger på 200000 måste alltså 68000 NOK deponeras.

\section{Lösning}

Nordkalottens gränstjänst har arbetat tillsammans med Gränshinderrådets medlemmar Svein Ludvigsen och Sten Palmgren för att lösa hindret. 11 september 2015 kom en ändring i importinstruktion 49/2015 som innebär att resande istället ska ge en muntlig deklaration av fordonet till den finska tullen. Därutöver ska blanketten $613 \mathrm{r}$ fyllas ut med nödvändiga upplysningar. 


\title{
Avklarade gränshinder under 2014
}

\author{
Språkkrav för danska yrkesutbildningar
}

Löst

\section{Problem vid flytt till Island med kvalifikationsperiod på 6 månader om E-104 blankett saknas}

Avskrivna av berörda departement.

\section{Arbetspraktik i ett annat nordiskt land}

En person som är arbetslös kan inte genomföra praktik i ett annat nordiskt land, eftersom de nationella regelverken primärt baseras på att praktik genomförs i bosättningslandet.
Svar från MR-A:

Danska Rambøll har på uppdrag av ÄK-A undersökt gränshindret. Baserat på rapportens slutsatser har ÄK-A inställt till MR-A att gränshindret ska tas bort från A-sektorns prioriteringslista. Gränshindret var på dagordningen på MR-A möte i Köpenhamn den 20 november 2014 och länderna beslutade gemensamt att inte arbeta vidare med frågan om arbetspraktik.

Läs mer i gränshinderdatabasen, granshinder.norden.org, gränshinder nr: 14-002. 


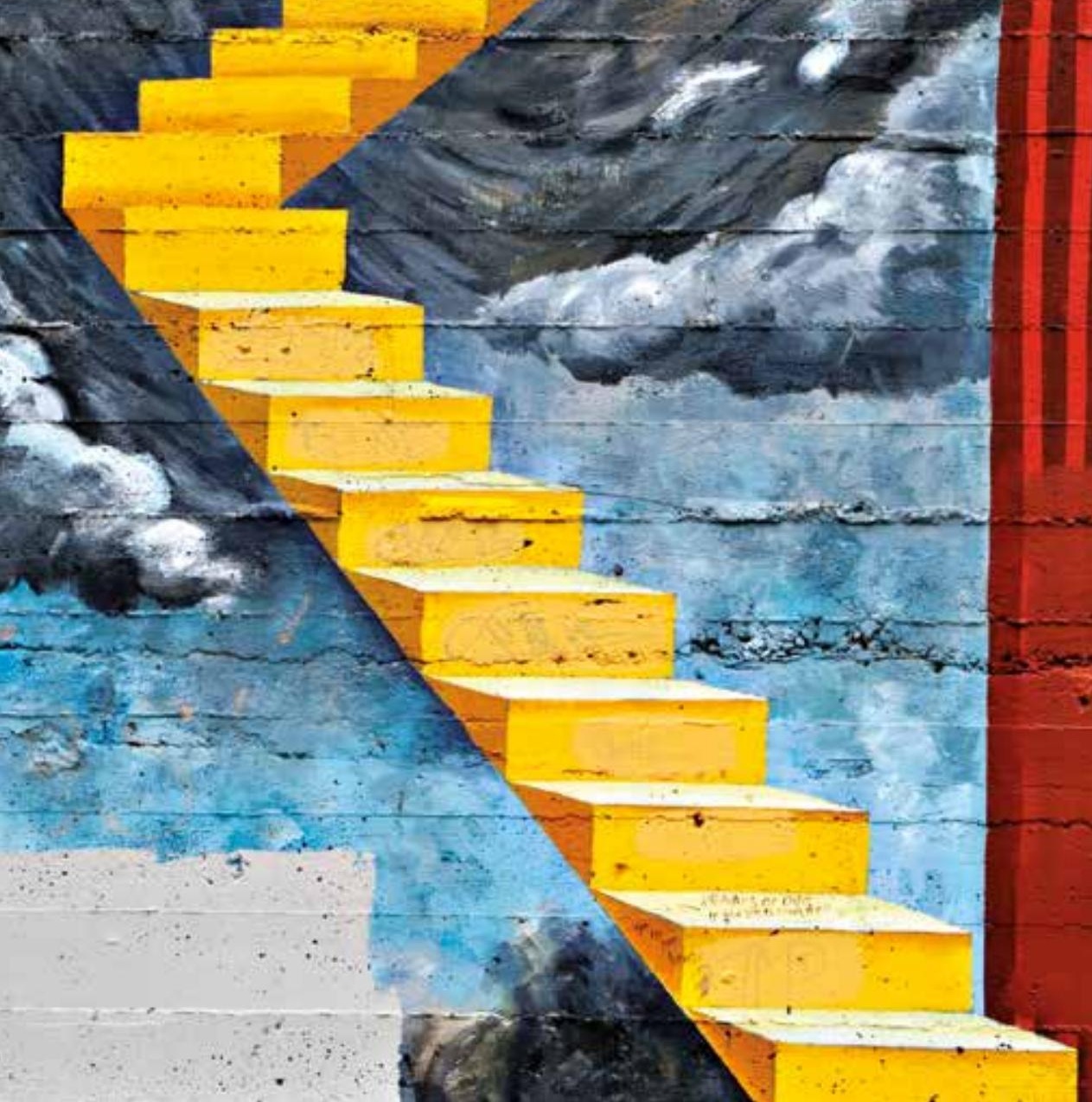




\section{Involvering av arbetsmarknadens parter}

\section{Norden som förebild - Tillväxtkonferens om gränshinder}

Den 30 april 2015 hölls en näringslivskonferens på Børsen i Köpenhamn med fokus på gränshinder som begränsar tillväxten i Norden. Där deltog bland annat den danska statsministern och samarbetsministrarna från Danmark och Färöarna. Konferensen initierades av den danske samarbetsministern Carsten Hansen, och är en del av Danmarks ordförandeskapsprogram.

Inför konferensen bildades en arbetsgrupp med syfte att identifiera, prioritera och sammanställa en lista över nordiska gränshinder som hämmar tillväxten, inklusive lösningsförslag. Arbetsgruppen leddes av Gränshinderrådets danske medlem och tillika ordförande Ole Stavad, och koordinerades av danska Utrikesministeriet. Representanter från arbetsmarknadens parter i Danmark utgjorde medlemmarna i gruppen, men gruppen koordinerade sitt arbete med sina nordiska systerorganisationer. Dessutom ingick Gränshinderrådets sekretariat i arbetet.
I samband med att listan med femton gränshinder presenterades vid näringslivskonferensen meddelade samarbetsministern att den dessutom skulle sändas vidare till den danska statsministern i ett brev, eftersom förslagen var tydliga, genomtänkta och väl förankrade i Norden. Förslagen inkluderade:

- Bildandet av ett nordiskt forum för arbetsmarknadens parter.

- Stärkta informationsinsatser för näringslivet i Norden.

Beträffande övriga tretton hinder är många av dessa redan prioriterade av Gränshinderrådet.

Den dåvarande danska statsministern, Helle Thorning-Schmidt, besvarade brevet och vidarebefordrade det till berörda danska departement. Den fortsatta processen kring tillväxtfrågor med koppling till arbetsmarknadens parter bör föras vidare till nästa ordförandeland. För att säkra detta på sikt har en lathund/drejebog utvecklats av Gränshinderrådets sekretariat.
På det nordiska statsministermötet 3 oktober 2015 beslutades att Nordiska ministerrådets generalsekreterare Dagfinn Høybråten skulle se över möjligheten för en stärkt dialog mellan arbetsmarknadens parter i Norden, Gränshinderrådet samt relevanta ministrar.

De nordiska statsministrarna möttes igen i Reykjavik 28 oktober där de presenterades för ett förslag kring förstärkt diskussion om hinder som begränsar mobilitet och tillväxt i Norden. Statsministrarna gav generalsekreteraren $\mathrm{i}$ uppdrag att gå vidare med att förbereda en dialog om detta. Man antog även en deklaration om vikten av en effektiv dialog mellan arbetsmarknadens parter i Norden, Gränshinderrådet och berörda ministerier. 


\section{Erklæring fra de nordiske statsministre vedrørende vækst- og grænsehindringer i Norden}

Vi vil fjerne de grænsehindringer, der hæmmer væksten i Norden.

Vi ser desværre eksempler på, at forskelle i regler eller krav til produkter afholder virksomheder fra at udvide deres forretning til de øvrige nordiske lande og derved udnytte det store nordiske marked med 26 millioner forbrugere. Det er ærgerligt. For det hindrer skabelse af vækst og arbejdspladser i Norden.

Og det gør det sværere at tiltrække investeringer udefra.

Vi hilser på den baggrund Grænsehindringsrådets arbejde med at forebygge og fjerne grænsehindringer velkommen, og ser fortsat Grænsehindringsrådet som de nordiske regeringers centrale aktør i dette arbejde.
Samtidig anerkender vi, at erhvervsorganisationerne og arbejdsmarkedets parter har fingeren på pulsen og ved, hvor de virkelig væksthæmmende grænsehindringer findes. Derfor vil vi nu gennem Grænsehindringsrådet intensivere dialogen med repræsentanter for disse, så de inddrages yderligere i det nordiske arbejde med at fjerne grænsehindringer. Organisationerne kan være med til at finde løsninger på de grænsehindringer, der fortsat består mellem de nordiske lande. Det vil være en fordel for alle nordiske virksomheder og borgere.

Vi giver derfor generalsekretæren for Nordisk Ministerråd i opdrag at sikre en struktureret dialog, hvor organisationerne kan mødes med Grænsehindringsrådet og relevante nordiske ministre for sammen at få løst denne opgave.

28. oktober 2015 


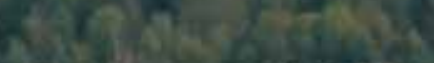

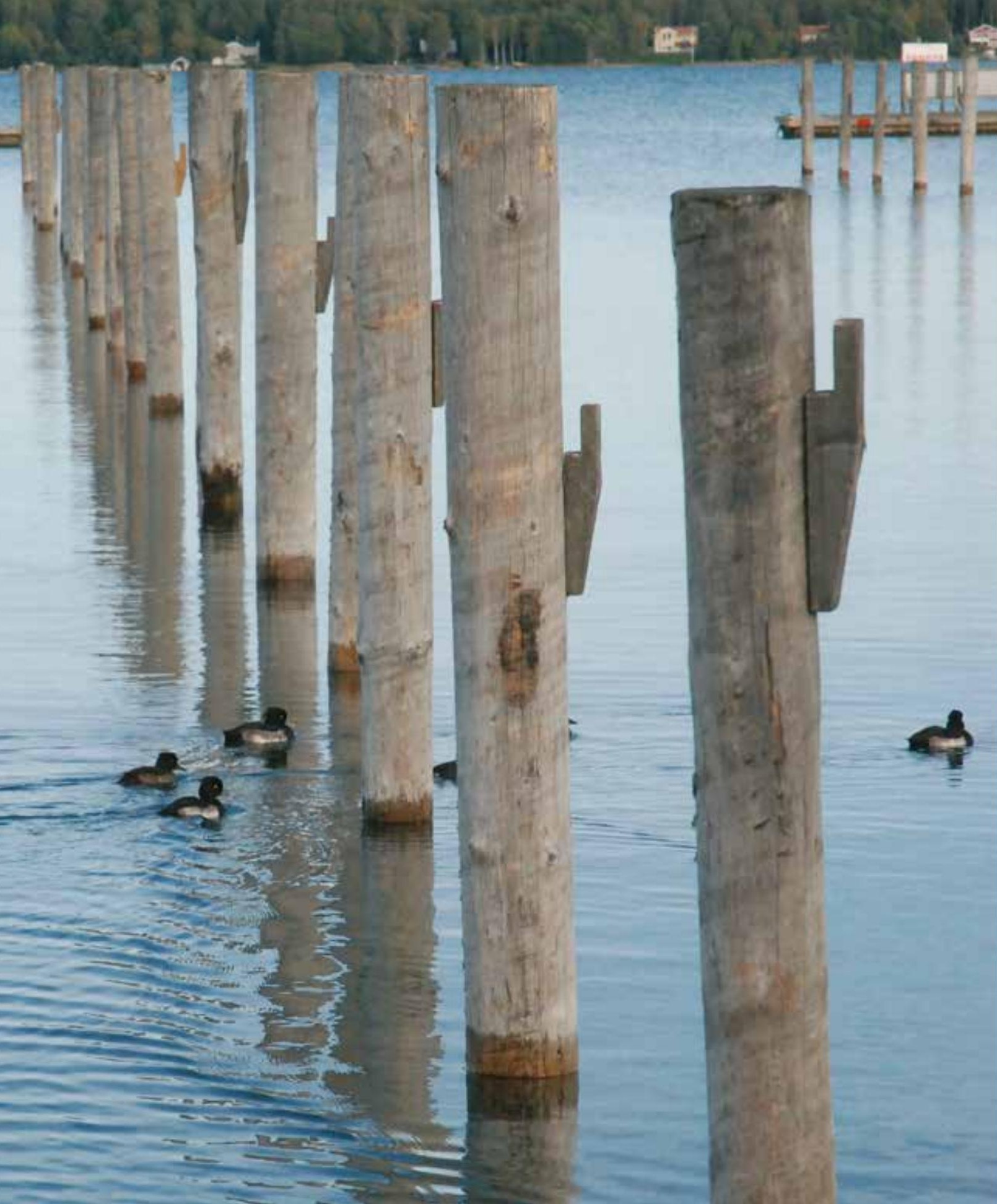




\section{Nordiska Rådets Gränshindergrupp}

Nordiska rådets Presidium utsåg hösten 2013 Bertel Haarder till Nordiska rådets representant i Gränshinderrådet, som upprättades 2014. Samtidigt bad Presidiet samtliga utskott i Nordiska rådet att utse en kontaktperson för gränshinder. Denna konstellation har därefter under ledning av Bertel Haarder utvecklats till den informella gruppen Gränshindergruppen.

Gränshindergruppen har senare kompletterats för att säkra en bredare representation bland nationaliteter och partigrupper.

Efter Folketingsvalet i Danmark våren 2015 avlöstes Bertel Haarder av Marit Nybakk som ordförande för Gränshindergruppen, och därmed även som Nordiska rådets representant i Gränshinderrådet.

\section{Prioriteringar}

Vid Gränshindergruppens bildande beslutades att gruppen som utgångspunkt inte skulle driva och prioritera egna gränshinder, utan istället skulle stödja Gränshinderrådets pågående arbete. Gränshinderrådet har dock bett Gränshindergruppen om synpunkter på vilka hinder som bör prioriteras.
Efter att Gränshinderrådet fattat beslut om prioriteringar har Gränshindergruppen även uppmanats att välja ut hinder som man önskar att följa särskilt. Under 2015 har Gränshindergruppens medlemmar eller dessas utskott fokuserat på följande:

- Norska tull- och momsregler.

- Beskattning av äkta gränsgångare.

- Erkännande av yrkeskvalifikationer.

- Norsk skattepraxis och administrativa bördor.

Under 2015 har Gränshindergruppen uppmanats att kontakta Gränshinderrådets medlemmar för att föreslå samarbete kring enskilda hinder.

\section{Gränshindergruppens mötesverksamhet}

Gränshindergruppen har hållit sina möten i samband med utskottens och partigruppernas samlingar. Som regel har det varit fyra möten per år. Gränshindergruppens möten har för det mesta hållits före utskottsmötena, vilket har gett möjlighet att återkoppla till utskotten.

\section{Framtid}

Gränshindergruppens framtid är oklar eftersom Nordiska rådets utskottsstruktur ska reformeras. Dessutom kommer gränshinderfrågorna från och med januari 2016 att skötas av utskottet för tillväxt och utveckling (tidigare Näringsutskottet).

\section{Rekommendationer från Nordiska rådet}

Gränshindergruppen har även tagit initiativ till nya medlemsförslag som sedermera har blivit till rekommendationer från Nordiska rådet:

- Implementering av EU-direktiv. http://www.norden.org/da/ nordisk-raad/sager-og-dokumenter/a-1630-naering

- Regeringarnas uppdrag till sina centrala myndigheter. http://www.norden.org/da/ nordisk-raad/sager-og-dokumenter/a-1631-naering

Ingen av dessa rekommendationer är ännu avskrivna eller avslutade. 


\section{Informationsarbetet}

Den nordiska informationstjänsten Hallå Norden och de tre gränsregionala informationstjänsterna Nordkalottens Gränstjänst, Grensetjänsten och Öresunddirekt, har särskild betydelse för det nordiska gränshinderarbetet, och finansieras i olika omfattning av Nordiska ministerrådet. Informationstjänsterna underlättar för privatpersoner och företag som vill röra sig mellan de nordiska länderna, och behöver hjälp med att finna information om regler och myndighetskontakter.

Dessa tjänster är Gränshinderrådets strategiska frontlinje. De registrerar alla förekommande gränshinder, samt analyserar om dessa kan lösas lokalt, regionalt eller nationellt. Identifierade hinder inrapporteras därefter till Gränshinderrådets sekretariat och till den nordiska gränshinderdatabasen. Tillsammans har informationstjänsterna under perioden 1 november 2014-31 oktober 2015 erhållit över 1520000 webbesök, samt cirka 47500 personliga kontakter (besök, e-post, telefon och gruppbesök). Informationstjänsterna och de gränsregionala kommittéerna deltar också i eventuella förmöten inför Gränshinderrådets ordinarie möten. Gränshinderrådets sekretariat ingår i de gränsregionala styrgrupperna samt $i$ Hallå Nordens arbetsgrupp.
Gränshinderarbetet har effektiviserats genom att Gränshinderrådets sekretariat tillsammans med informationstjänsterna har utvecklat en gemensam samarbetsplattform, LOTS-gruppen Nordiska Lösningsfokuserade Orienterande Tjänstgörande Samordnare. LOTS-gruppen har i samarbete med Gränshinderrådets sekretariat utvecklat och implementerat en gemensam handlingsplan för hur man ska effektivisera gränshinderarbetet och informationsinsatserna.

Under 2015 har LOTS-gruppen inrapporterat gränshinder till Gränshinderrådet, och startat gemensamma projekt i syfte att förbättra och understödja samarbetet mellan organisationerna. Man har även påbörjat utvecklingen av en gemensam kommunikationsplan i syfte att öka synligheten gentemot privatpersoner, företag och myndigheter. Dessutom deltar elva av tolv gränshinderregionala kommittéer i LOTS.

\section{Hallå Norden}

Hallå Norden är en nordisk informationstjänst för privatpersoner som vill flytta, arbeta eller studera i ett annat nordiskt land. Den primära uppgiften är att informera och guida privatpersoner via webb, telefon och e-post. Hallå Norden har kontor i de fem nordiska länderna samt på Åland och Färöarna, dessutom har man under 2015 utökat verksamheten med ett kontor på Grönland. Utöver kontoren finns en webbaserad informationsportal placerad i Köpenhamn som stödjer Hallå Norden-kontoren.

Webben har under de första åtta månaderna haft 990000 besök, samt 2700 förfrågningar. Hallå Norden har under året arrangerat möten samt evenemang, konferenser, seminarier, workshops etc. runt om i Norden, både som enskild aktör och i samarbete med andra. Innehållet i dessa arrangemang har främst varit identifierade gränshinder. Målgruppen för dessa arrangemang har främst varit samarbetspartners och beslutsfattare inom både det offentliga och det privata. Hallå Norden rapporterar identifierade gränshinder direkt till Gränshinderrådets sekretariat, och har dessutom varit en aktiv samarbetspartner i utvecklingen av den nordiska gränshinderdatabasen.

\section{Nordkalottens Gränstjänst - Haparanda Torneå och Skibotn} Nordkalottens gränstjänst är en informationstjänst för privatpersoner och näringsliv i gränsregionerna mellan Sverige, Norge och Finland. Under perioden dokumenterades 3700 kontakter med privatpersoner och företag. Därutöver har Nordkalottens hemsida under samma period haft 40000 besök. 
Skibotnkontoret är bemannat med två medarbetare, varav en från NAV (Norges arbetsförmedling). Kontoret i Haparanda Torneå är fortfarande bemannat med en person. Nordkalottrådets ambition är att utveckla Nordkalottens gränstjänst genom ett Interreg V A Nord-projekt under 2016-2018. Tillsammans med regionens näringslivsorganisationer ska Nordkalottrådet utveckla nödvändig kompetens och bilda ett nätverk för att erbjuda vägledning till företag i frågor som gäller verksamhet över nationsgränserna. Ansökan görs under 2015.

Bland Nordkalottens möten och arrangemang under 2014 märks bland annat en temadag för pensionärer som flyttat utomlands, pensionärer som får pension från utlandet, gränsgångare och andra berörda. Man har även noterat en ökning i antalet frågor från små och medelstora företag.

\section{Grensetjänsten}

Grensetjänsten är en informationstjänst för privatpersoner och näringsliv i gränsregionen mellan Sverige och Norge. Under 2014 har man haft cirka 19000 personliga kontakter och 71000 besök på hemsidan. På grund av ökad efterfrågan från företag har Grensetjänsten påbörjat en del förändringar, bland annat lanserades en ny hemsida i januari 2015. Grensetjänsten driver sedan 2003 också ett Grenseråd som möts två gånger per år.

I maj 2013 beslutades att Grensetjänsten även ska arbeta med förenklingar mellan länderna. Det har genomförts två möten i förenklingsgruppen, som bland annat har resulterat i nya samarbeten mellan myndigheter som gjort processer snabbare. Ett lagförslag som svenska regeringen lämnar i september 2015 kan komma att lösa ett antal gränshinder.

\section{Öresunddirekt}

Öresunddirekt är en informationstjänst för privatpersoner och näringsliv $i$ gränsregionen mellan Sverige och Danmark. Antalet personliga kontakter på Öresunddirekt i Sverige uppgick 2014 till 22 000. Öresunddirekts webbsidor har tillsammans haft 420000 besök. Öresunddirekt har instiftat ett näringslivspris, Öresunddirekt Business Award, där företag som har gjort en fram-

gångsrik "resa över Sundet" premieras. Öresunddirekt arbetar med att göra hemsidorna tillgängliga på engelska för att möta en stigande efterfrågan. Under hösten 2015 har hållits en workshop för danska och svenska a-kasseaktörer och jobbvägledare i regionen.

Öresunddirekt ingår i Öresundskommitténs gränshinderarbetsgrupp. I denna arbetsgrupp samordnas det Öresundsregionala gränshinderarbetet.

\section{Regionalt samarbete}

De nordiska gränsregionerna och regionerna har olika prioriteringsområden beroende på de olika behov som finns. De viktigaste prioriteringsområdena ligger främst inom arbetsmarknad, utbildning, hälsa, transport och näringsliv. Bland aktörerna finns nationella myndigheter, samt gränsregionala aktörer som gränskommittéer och de gränsregionala informationstjänsterna.

I det nordiska regionalpolitiska samarbetsprogrammet 2013-2016 framhålls gränskommittéerna i Norden som en viktig aktör för arbetet med att identifiera och riva ner gränshinder i Norden. Gränskommittéerna tar årligen emot tillsammans 9550000 DKK i stöd från Nordiska ministerrådet till gränsregionala aktiviteter. Medlen styrs av den nordiska gränsregionala strategin som godkänts av de nor-diska samarbetsministrarna. En annan viktig roll för Gränskommittéerna är att nedbryta de informella gränshindren såsom kulturella och språkliga olikheter. Kommittéerna är tätt kopplade till arbetet med gränshinder och särskilt till identifiering, utredning och rapportering till relevanta aktörer. 


\section{Det förebyggande arbetet}

Samarbetsministrarna har i sin strategi och handlingsplan för nordisk mobilitet 2014-2017 slagit fast att gränshinderarbetet även ska arbeta förebyggande. De nordiska statsministrarnas deklaration från 2013 om mobilitet $\mathrm{i}$ Norden fastställde att det ska arbetas för att genomföra EU-lagstiftning så enhetligt som möjligt för att förhindra barriärer och hinder. Där framgår också att länderna ska kommunicera inbördes när man inför nya lagar och regler för att förhindra att nya gränshinder uppstår. Det bör vidare införas krav på att undersöka konsekvenser för mobilitet inom Norden eller EU vid införande av ny lagstiftning.

Gränshinderrådet och Nordiska ministerrådets sekretariat har tagit fram nio konkreta förslag till insatser ifall de nordiska länderna samt Färöarna, Grönland och Åland önskar att ingå i ett samarbete om förebyggande av gränshinder. Åtgärderna är tänkta att komplettera varandra och är indelade i tre nivåer: EU/EES-rättsligt, nordiskt och nationellt.

\section{Insatser på EU-nivå:}

- Upprättande av en arbetsgrupp som ska säkra ett enhetligt genomförande av direktivet om utstationering. Länderna har redan haft en tät dialog i samband med mötena i Nordiska arbetsrättsutskottet. Det undersöks om man kan hjälpa länderna med att genomföra gemensam informationsinsamling och kartlägga existerande dokumentation.

- Screening av nya EU-direktiv. Det danska ordförandeskapet har påbörjat en undersökning om hur detta kan genomföras, ett arbete som sedan vidareförs av det finska ordförandeskapet 2016. Tanken är att länderna själva tar initiativ till att screena nya direktiv för att kunna koordinera genomförandet där det behövs. Mer konkret arbetar man på att de roterande ordförandeskapen ska införa rutiner för att välja ut ett antal direktiv att samarbeta kring.

Tanken är att länderna ska orientera om åtgärder i samband med genomförandet av direktiv och diskutera eventuella gränshinder som kan uppstå.
- Ett mer målinriktat utbyte av tjänstemän. Det har länge funnits ett nordiskt system för utbyte av tjänstemän, men denna saknar strategi och struktur för genomförande av EU/EES-lagstiftning, något som har efterfrågats av länderna.

- Ett seminarium för institutioner som arbetar med förordning 883/2004 om samordning av de sociala trygghetssystemen. En rapport kommer att utarbetas under 2016 om vilka utmaningar de enskilda ländernas institutioner står inför.

\section{Insatser på nordisk nivå:}

- En undersökning om det är möjligt att i högre grad använda gemensamma vägledningar till nordiska avtal. Detta ska i så fall leda till att det i samband med löpande revideringar av nordiska avtal utarbetas överskådliga vägledningar. Sådana har tidigare framställts till de centrala nordiska konventionerna om exempelvis socialförsäkringar samt socialbidrag- och tjänster. 
- Det nordiska samarbetets hemsidor ska i högre grad kunna användas av länderna till att orientera sig om existerande gränshinder och förebyggande insatser. Detta görs genom att utveckla en text och en mall för en hemsida om nordiskt rättsligt samarbete, som departement/ministerier kan anpassa efter egna behov. Därutöver ska Nordiska ministerrådets hemsida om gränshinder kunna användas när man utreder om lagförslag kan orsaka gränshinder.

- Under Nordiska rådets session i Reykjavik hölls ett möte mellan representanter för Gränshinderrådet och talmännen/formændene for de nordiska parlamenten. Syftet var att väcka uppmärksamhet hos parlamenten för eventuella nordiska gränshinder som en följd av ny lagstiftning.
- Arbetet med att säkra mobilitet på utbildningsområdet har fortsatt, bland annat genom arbetet med Reykjavik-deklarationen, med de nordiska masterutbildningarna och med ett arbete om behörighet till högre utbildning. Arbetet på att förebygga gränshinder kan bäst lösas genom att integrera arbetet $\mathrm{i}$ de löpande processerna. Bättre förebyggande arbete och tätare dialog med Hallå Norden är andra möjligheter.

\section{Insatser på nationell nivå:}

- Här har diskuterats vilka kriterier i de nationella instruktionerna för det lagförberedande arbetet som indikerar att det är relevant att beskriva konsekvenser för det nordiska samarbetet. Som en del av detta arbete har en uppdaterad överblick av de nationella instruktionerna tagits fram. Detta ska tillsammans med åtgärderna med parlamenten och hemsidan utgöra grunden för en diskussion om insatserna kan koordineras bättre mellan länderna. 


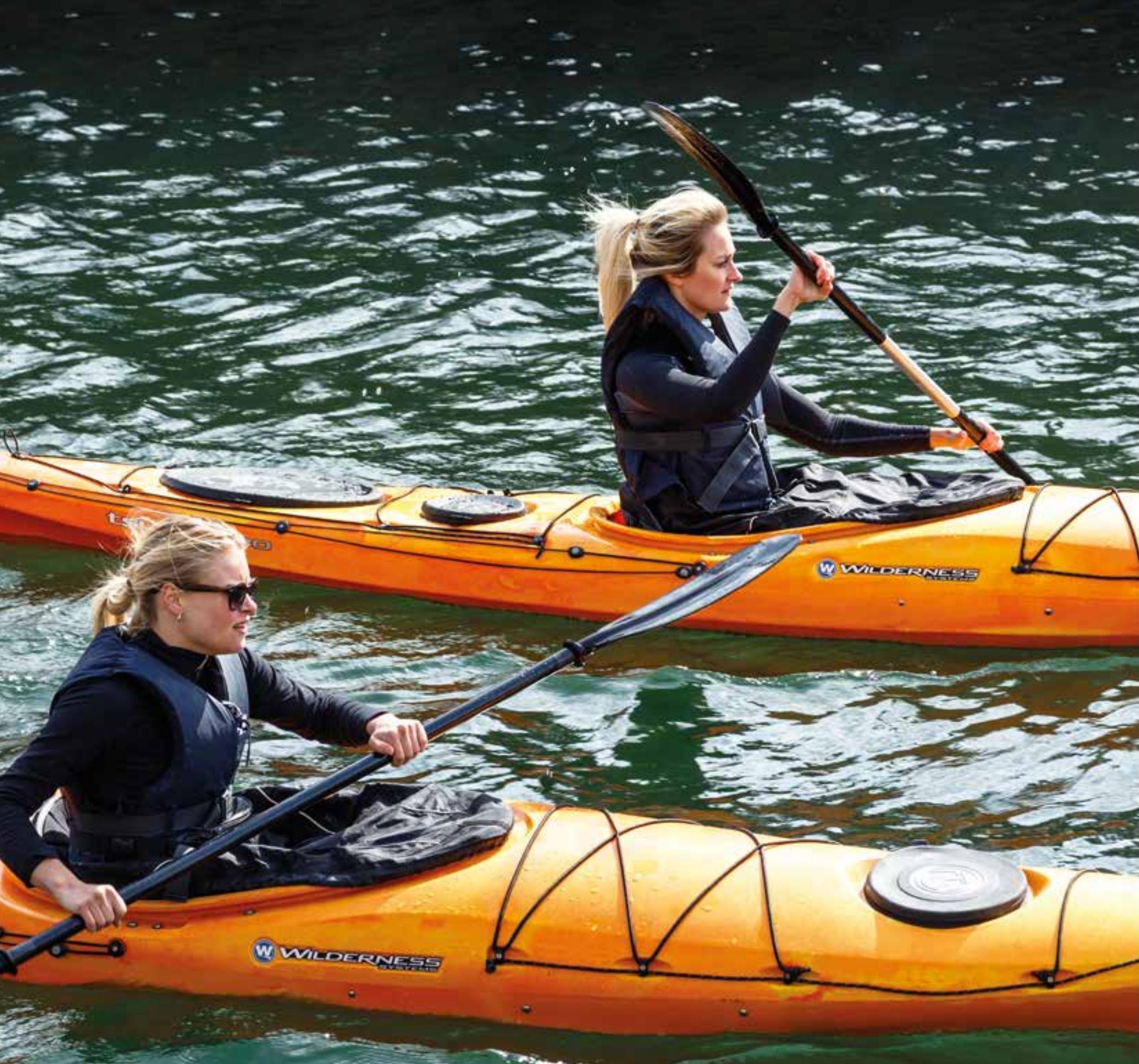




\section{Efterord}

Gränshinderfrågorna är ett prioriterat område för Finlands ordförandeskap 2016 med särskild tyngdpunkt på frågor som gäller tillväxt och företagsverksamhet.

Gränshinderrådet har nu varit verksamt i två år, först under isländskt och sedan under danskt ordförandeskap. Man kan utan överdrift säga att rådet har befäst sin ställning som en inflytelserik aktör $i$ arbetet med att underlätta mobiliteten i Norden för medborgare och företag.

Grunden har nu lagts för ett framgångsrikt arbete: de nordiska parlamenten är starkt engagerade för att i lagstiftningsarbetet lägga vikt på att gränshinder undanröjs och för att nya inte uppkommer. Statsministrarna har i sin deklaration i oktober gett generalsekreteraren i uppdrag att vidareföra dialogen med arbetsmarknadens parter. Många organisationer har satt gränshinderfrågorna på sin agenda.
Gränshinderarbete innebär inte endast att avskaffa hinder och att förhindra att nya uppkommer. Minst lika viktigt är det att de människor och företag som rör sig eller är verksamma över gränserna har möjligheter att lätt få information om skillnader i regelverk och praxis, så att de vet hur de ska handla utan att stöta på svårigheter. Därför är det oerhört viktigt att rådgivningsarbetet får tillräckliga resurser. Det arbete som Hallå Norden och de gränsregionala informationstjänsterna står för är mycket värdefullt och måste säkerställas. Det kunde även gärna utvidgas till företagsrådgivning.

Gränshinderrådet biträds av Nordiska ministerrådets sekretariat. Utan sekretariatets insatser skulle framgångarna utebli. Sekretariatet ska ha ett varmt tack för sitt arbete hittills!

Året 2015 har inneburit stora förändringar för Europa, vilkas konsekvenser är svåra att förutse. De flyktingströmmar som kommer ända upp till Norden och den terrorism som lurar som ett ständigt hot får konsekvenser också för rörligheten mellan länderna. Det är inte längre självklart att våra samhällen kan förbli lika öppna som förr. Detta är frågor som länderna inte klarar av att lösa ensamma. Låt oss hoppas att det nordiska samarbetet kan växa och stärkas så att länderna gemensamt kan tackla utmaningarna!

Det finns många spännande projekt för Gränshinderrådet som förhoppningsvis genomförs 2016. Finalen går av stapeln i Torneå 8-9 december 2016, där samarbetsministrarna och Gränshinderrådet möts.

\section{Sten Palmgren}

Medlem i Gränshinderrådet

2014-2015 



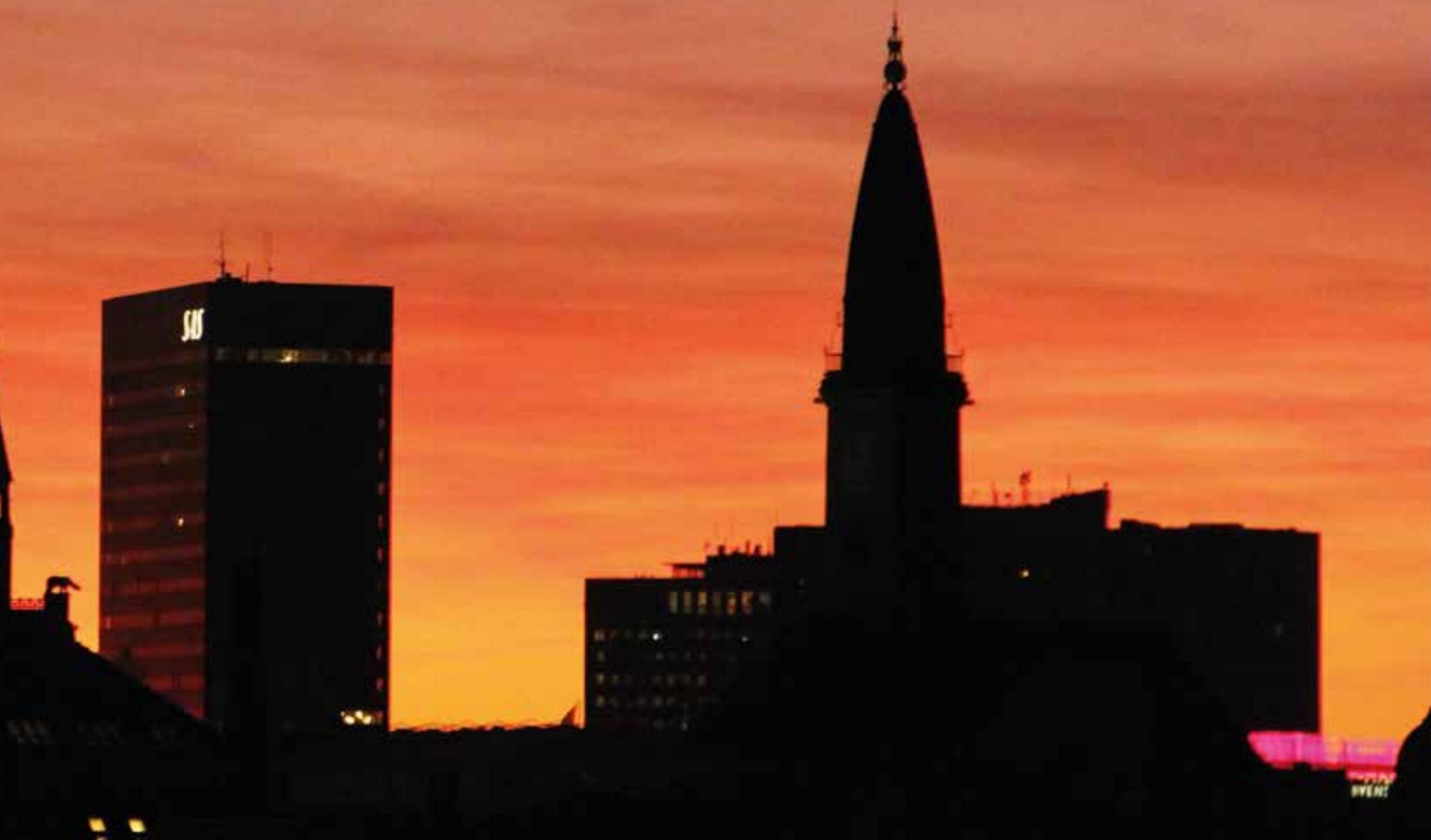




\section{norden}

Nordiska ministerrådet

Ved Stranden 18

DK-1061 København K

www.norden.org

ANP 2015:797

- $\#$ \#

$-25-19-13-\frac{i}{9}-\frac{i}{5}-\frac{i}{3}-\frac{i}{1}-i$

-33- $-26-20-14-10-67-\frac{1}{2}-$

$-39-34-27-21-15-6-77-47-$

$-45-40-35-28--\frac{1}{1}-16-11-8$

$49-46-41-2-29-22-17-12$

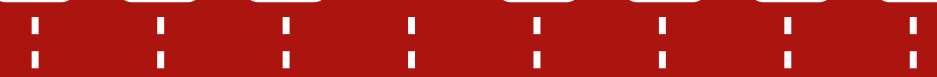

$-53-50-4-42-36-30-23-18$

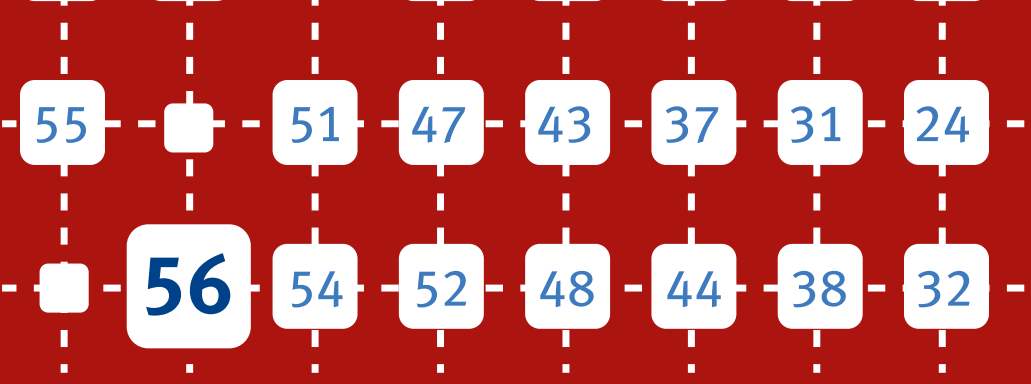

ISBN 978-92-893-4423-4 (PRINT)

ISBN 978-92-893-4424-1 (PDF) 